\title{
Assessing the surface water quality impacts of Marcellus shale development in Whiteday Creek watershed, West Virginia
}

\author{
D. Aaron Streets \\ West Virginia University
}

Follow this and additional works at: https://researchrepository.wvu.edu/etd

\section{Recommended Citation}

Streets, D. Aaron, "Assessing the surface water quality impacts of Marcellus shale development in Whiteday Creek watershed, West Virginia" (2012). Graduate Theses, Dissertations, and Problem Reports. 401.

https://researchrepository.wvu.edu/etd/401

This Thesis is protected by copyright and/or related rights. It has been brought to you by the The Research Repository @WVU with permission from the rights-holder(s). You are free to use this Thesis in any way that is permitted by the copyright and related rights legislation that applies to your use. For other uses you must obtain permission from the rights-holder(s) directly, unless additional rights are indicated by a Creative Commons license in the record and/ or on the work itself. This Thesis has been accepted for inclusion in WVU Graduate Theses, Dissertations, and Problem Reports collection by an authorized administrator of The Research Repository @ WVU. For more information, please contact researchrepository@mail.wvu.edu. 
Assessing the surface water quality impacts of Marcellus shale development in Whiteday Creek watershed, West Virginia

\title{
D. Aaron Streets
}

\author{
Thesis submitted to the \\ Benjamin M. Statler College of Engineering and Mineral Resources \\ at West Virginia University \\ in Partial fulfillment of the requirements \\ for the degree of \\ Master of Science \\ in \\ Civil and Environmental Engineering
}

Leslie Hopkinson, Ph.D., Chair

John Quaranta, P.E., Ph.D.

Lian-Shin Lin, P.E., Ph.D

Department of Civil and Environmental Engineering

\author{
Morgantown, West Virginia \\ 2012
}

Keywords: Marcellus shale, watershed, hydraulic fracturing, water quality 


\section{ABSTRACT \\ Assessing the surface water quality impacts of Marcellus shale development in Whiteday Creek watershed, West Virginia}

\section{Aaron Streets}

Shale gas development in Central Appalachia will likely increase economic activity and help meet future energy needs; however, there are concerns over potential impacts to water resources. This research assessed impacts of drilling for gas in the Marcellus shale in the White Day Creek watershed in northern West Virginia. A total of eight stream sites, located both upstream and downstream of three permitted gas wells, were monitored. Two of the permitted wells were in the development phase while the third was actively being drilled. Water samples were collected during the bi-weekly sampling and analyzed at the National Research Center of Coal and Energy Analysis Laboratory. Benthic macroinvertebrate communities were monitored and rated using the West Virginia Stream Condition Index (WVSCI). Physical characteristics within the watershed were measured through pebble counts and cross sectional surveys. Continuous monitors were installed at the four sites surrounding the active drill site measuring conductivity, temperature, and stage.

Results indicated that none of the mean values for each testing parameter exceeded their respective EPA standard limit. Turbidity increased throughout the summer due to higher dissolved/suspended solids and lower water levels. Conductivity also increased during the summer as a result of temperature, ion concentration, and water level. Ion concentrations contributing to TDS of water samples remained constant during the monitoring period. The overall WVSCI score ranged from 47 to 80 . Medium grain size ranged from $<2$ to $67 \mathrm{~mm}$. From the results, it could not be determined if development in the Marcellus shale impaired surface water quality. Results indicated that surface water quality at each monitoring site was not impaired and that testing parameters remained at below EPA standard limits. 


\section{ACKNOWLEDGEMENTS}

The author would like to thank all the people who committed their time and effort to execute the monitoring plan for this research project. Persons of particular importance include Dr. Leslie Hopkinson for serving as committee chairperson and academic advisor, Ben Mack, Melissa O'Neal, and other employees at WRI for providing assistance on methodology, equipment issues, and data entry models, and Manuel Barrueta and Nicholas Akers for their assistance in the collection of field data. The author would also like to thank Dr. John Quaranta and Dr. Lance Lin for serving as committee members. In addition to his colleagues, the author would like to thank his family and fiancé for their continuous support. Without the support of these individuals, this research would have not been successful. 


\section{GRANT INFORMATION}

This work was performed in support of the National Technology Energy Technology Laboratory's ongoing research on shale development under RES contract 1000023.

This project was funded by the Department of Energy, National Energy Technology Laboratory, an agency of the United States Government, through a support contract with URS Energy \&Construction, Inc. Neither the United States Government nor any agency thereof, nor any of their employees, nor URS Energy \& Construction, Inc., nor any of their employees, makes any warranty, expressed or implied, or assumes any legal liability or responsibility for the accuracy, completeness, or usefulness of any information, apparatus, product, or process disclosed, or represents that its use would not infringe privately owned rights. Reference herein to any specific commercial product, process, or service by trade name, trademark, manufacturer, or otherwise, does not necessarily constitute or imply its endorsement, recommendation, or favoring by the United States Government or any agency thereof. The views and opinions of authors expressed herein do not necessarily state or reflect those of the United States Government or any agency thereof. 


\section{TABLE OF CONTENTS}

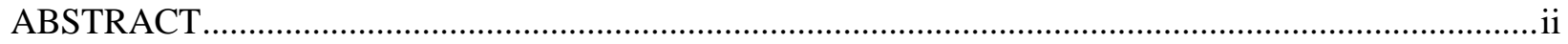

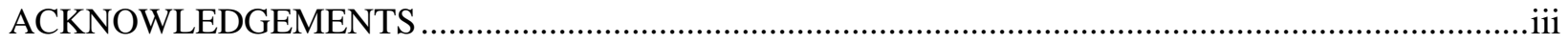

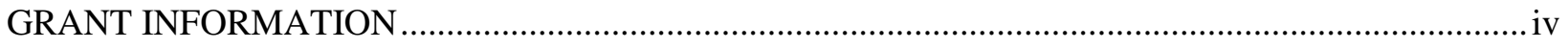

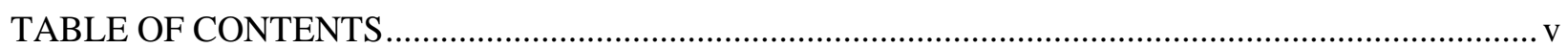

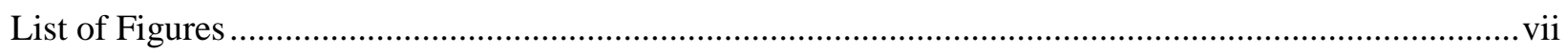

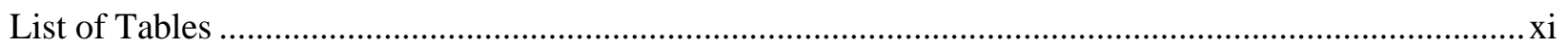

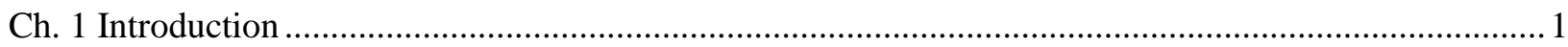

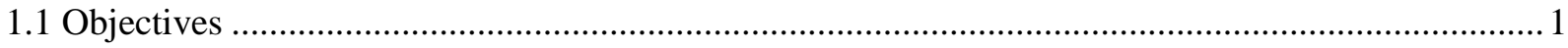

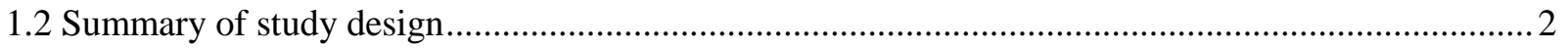

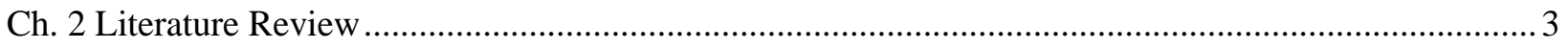

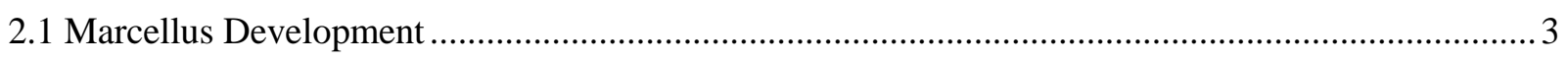

2.2 Regulations related to surface water ................................................................................... 4

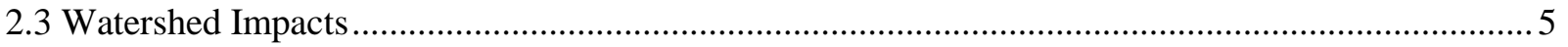

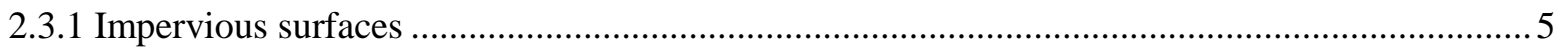



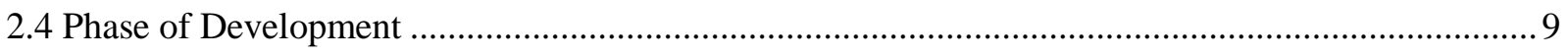

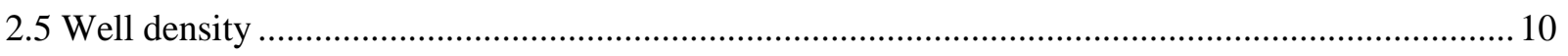

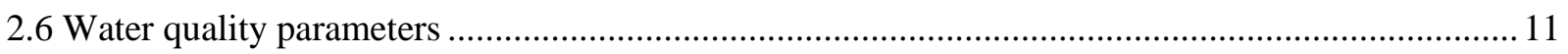

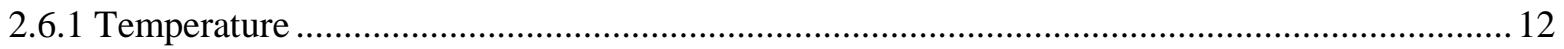

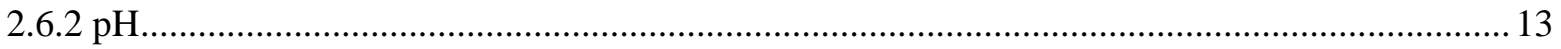

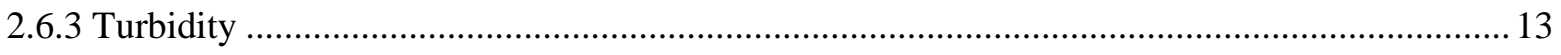

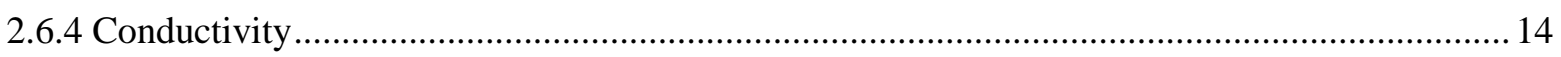

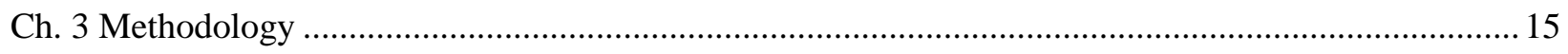



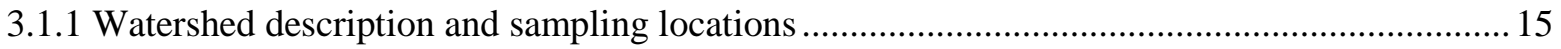

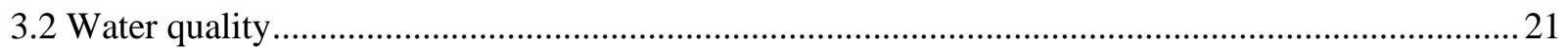

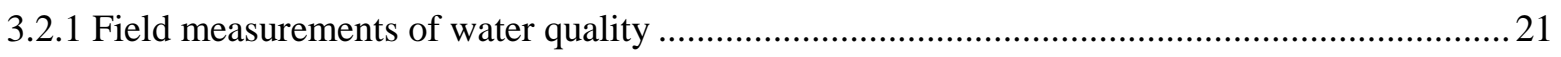

3.2.2 Continuous measurements of water quality ................................................................... 21



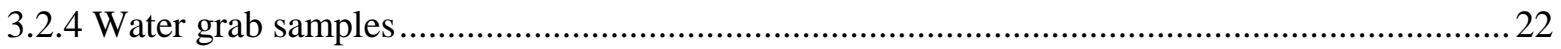

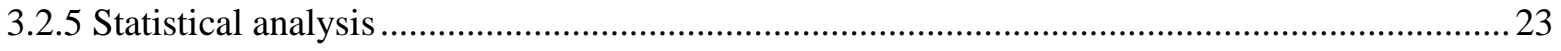

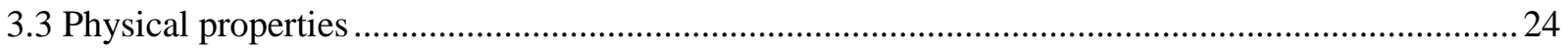

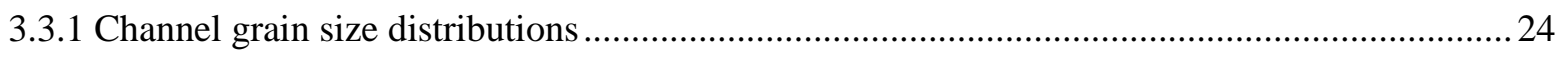




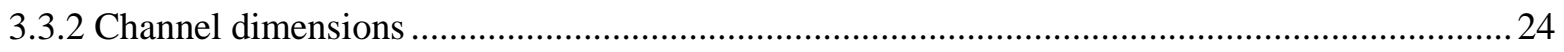

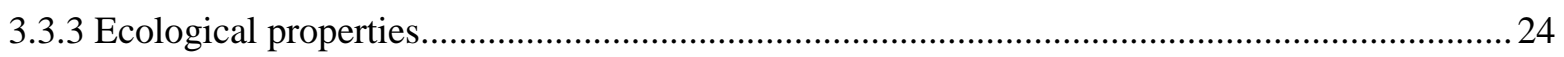

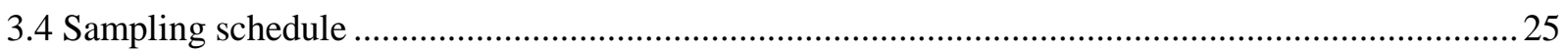

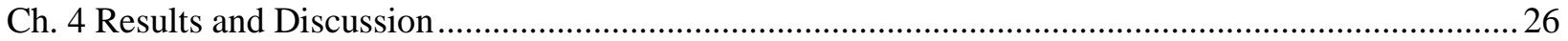

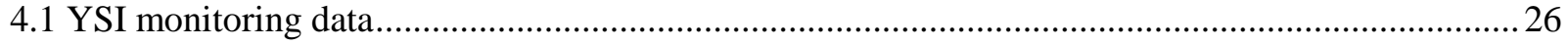

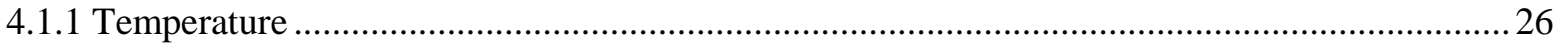

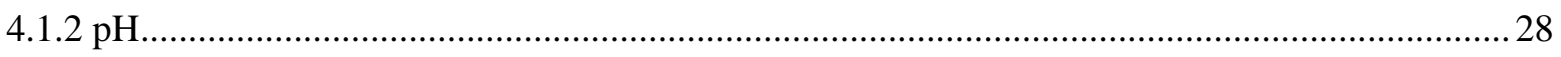

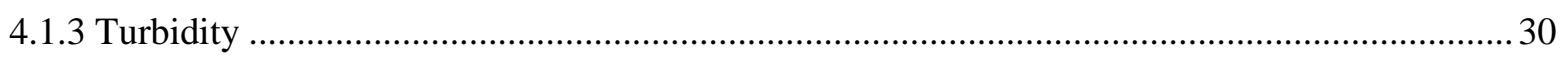

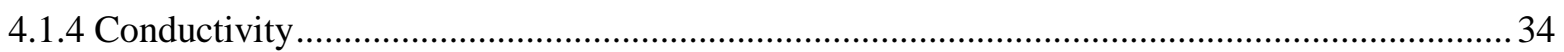

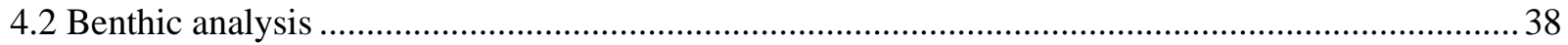

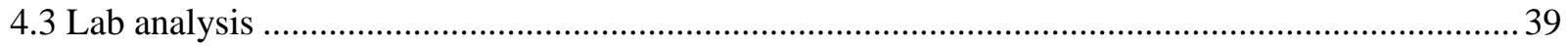



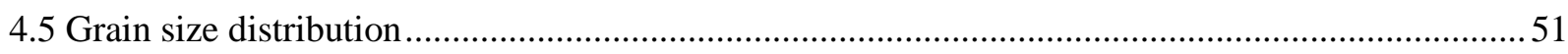

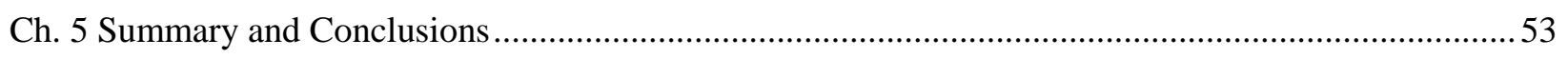

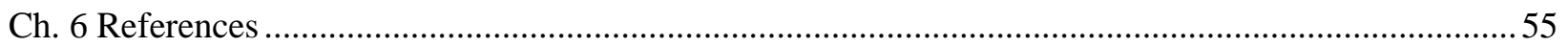

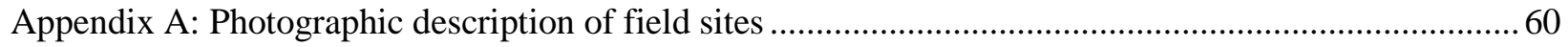

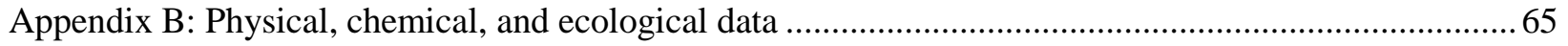




\section{List of Figures}

Figure 1. Whiteday Creek Watershed, depicting well and monitoring locations ................................... 16

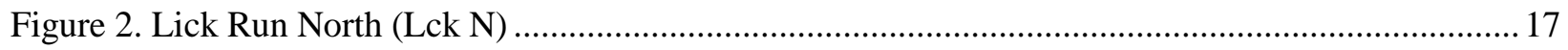

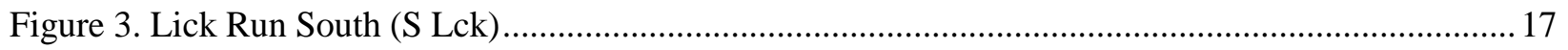

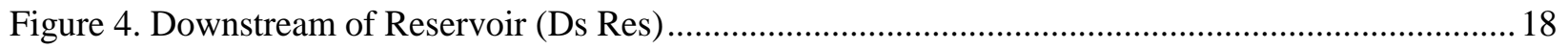

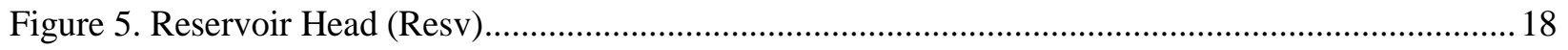

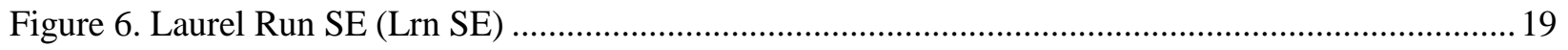

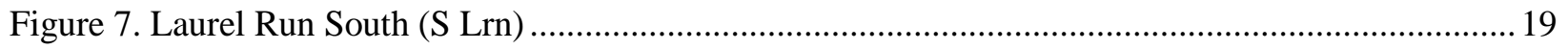

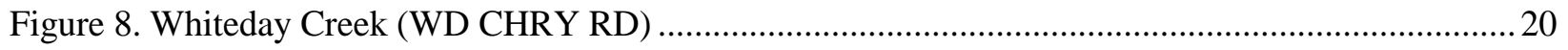

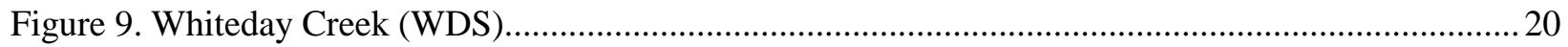

Figure 10. Deployed Levelogger Housing at Site 4 Reservoir ...........................................................22

Figure 11. Distribution of temperature $\left({ }^{\circ} \mathrm{C}\right)$ for the A) Daniel Morris permit pre-construction field site, B) Edwin Bunner permit active field site, and C) Orthodox Church Society inactive field sites (open markers represent upstream sites and solid markers are downstream sites).

Figure 12. Distribution of $\mathrm{pH}$ for the A) Daniel Morris permit pre-construction field site, B) Edwin Bunner permit active field site, and C) Orthodox Church Society inactive field sites (open markers represent upstream sites and solid markers are downstream sites).

Figure 13. Distribution of turbidity (NTU) for the A) Daniel Morris permit pre-construction field site, B) Edwin Bunner permit active field site, and C) Orthodox Church Society inactive field sites (open markers represent upstream sites and solid markers are downstream sites) .....................................................31

Figure 14. Site 3 South Lick Run (S Lck) on July 3, 2012 ............................................................... 32

Figure 15. Distribution of conductivity $(\mu \mathrm{S} / \mathrm{cm})$ for the A) Daniel Morris permit pre-construction field site, B) Edwin Bunner permit active field site, and C) Orthodox Church Society inactive field sites (open markers represent upstream sites and solid markers are downstream sites). ..........................................35

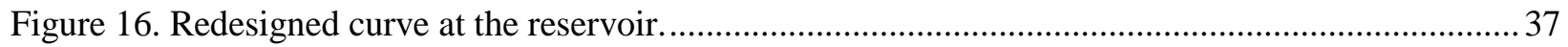

Figure 17. Calculated TDS (mg/L) from NRCCE analysis lab for teh Daniel Morris (Pre-construction) Permit field sites: A) S Lck and B) Lck N.....

Figure 18. Calculated upstream TDS (mg/L) from NRCCE analysis lab for the Edwin Bunner (active) Permit active field sites: A) Lrn SE and B) S Lrn. 48

Figure 19. Calculated downstream TDS (mg/L) from NRCCE analysis lab for the Edwin Bunner (active) Permit field sites: C) Resv and D) Ds Res.

Figure 20. Calculated TDS (mg/L) from NRCCE analysis lab for the Orthodox Church Society inactive field sites: A) WDS and B) WD CHRY RD.

Figure 21. Installation of Levelogger housing. 1) Begun by digging a channel to the bottom of the stream bed. 2) Measured lengths: back of the excavation to the center of stream and from the bottom of excavtion vertically to an elevation above estimated storm water levels. 3) Cut the 3 inch PVC pipe to measured lengths and connected them together with a 90 degree elbow pipe. The pipe assembled is called the 
Levelogger "housing". 4) Placed pipe in excavated channel and placed large rocks around the housing. 5) Place and compact the excavated soil back into its original location around the housing. 6) Is the finished product of the Levelogger housing functioning with device installed.

Figure 22. Photos of monitoring site of Lick Run North (Lck N). Pictures are referenced to stream flow direction: a) Upstream b) Downstream c) Left bank d) Right bank.

Figure 23. Photos of monitoring site South Lick Run (S Lck.. Pictures are referenced to stream flow direction: a) Upstream b) Downstream c) Left bank d) Right bank.

Figure 24. Photos of monitoring site Reservoir (Resv). Pictures are referenced to stream flow direction: a) Upstream b) Downstream c) Left bank d) Right bank.

Figure 25. Photos of monitoring site Laurel Run Southeast (Lrn SE). Pictures are referenced to stream flow direction: a) Upstream b) Downstream c) Left bank d) Right bank.

Figure 26. Photos of monitoring site South Laurel Run (S Lrn). Pictures are referenced to stream flow direction: a) Upstream b) Downstream c) Left bank d) Right bank.

Figure 27. Photos of monitoring site Whiteday Creek Cherry Run Road (WD CHRY RD). Pictures are referenced to stream flow direction: a) Upstream b) Downstream c) Left bank d) Right bank.

Figure 28. Photos of monitoring site South Whiteday Creek (WDS). Pictures are referenced to stream flow direction: a) Upstream b) Downstream c) Left bank d) Right bank.

Figure 29. Photos of monitoring site Downstream Reservoir (Ds Res). Pictures are referenced to stream flow direction: a) Upstream b) Downstream c) Left bank d) Right bank.

Figure 30. Grain size distribution at Lick Run North (Lck N). Data from pebble count that was collected on $5 / 24 / 12$.

Figure 31. Grain size distribution at Lick Run North (Lck N). Data from pebble count that was collected on $7 / 3 / 12$.

Figure 32. Grain size distribution at Lick Run North ( Lck N). Data from pebble count that was collected on $8 / 2 / 12$. . .66

Figure 33. Grain size distribution at Lick Run North ( Lck N). Data from pebble count that was collected on $8 / 30 / 12$. 66

Figure 34. Grain size distribution at south Lick Run ( S Lck). Data from pebble count that was collected on $5 / 24 / 12$.

Figure 35. Grain size distribution at south Lick Run (S Lck). Data from pebble count that was collected on $7 / 3 / 12$.

Figure 36. Grain size distribution at south Lick Run (S Lck). Data from pebble count that was collected on $8 / 2 / 12$.

Figure 37. Grain size distribution at south Lick Run (S Lck). Data from pebble count that was collected on $8 / 30 / 12$.

Figure 38. Grain size distribution at Reservoir (Resv). Data from pebble count that was collected on $5 / 24 / 12$.

Figure 39. Grain size distribution at Reservoir (Resv). Data from pebble count that was collected on $7 / 3 / 12$.

Figure 40. Grain size distribution at Reservoir (Resv). Data from pebble count that was collected on $8 / 2 / 12$ 
Figure 41. Grain size distribution at Laurel Run Southeast (Lrn SE). Data from pebble count that was collected on $5 / 24 / 12$.

Figure 42. Grain size distribution at Laurel Run Southeast (Lrn SE). Data from pebble count that was collected on $7 / 3 / 12$.

Figure 43. Grain size distribution at Laurel Run Southeast (Lrn SE). Data from pebble count that was collected on $8 / 2 / 12$.

Figure 44. Grain size distribution at south Laurel Run (S Lrn). Data from pebble count that was collected on $5 / 24 / 12$.

Figure 45. Grain size distribution at south Laurel Run (S Lrn). Data from pebble count that was collected on $7 / 3 / 12$.

Figure 46. Grain size distribution at south Laurel Run (S Lrn). Data from pebble count that was collected on $8 / 2 / 12$.

Figure 47. Grain size distribution at south Laurel Run (S Lrn). Data from pebble count that was collected on $8 / 30 / 12$.

Figure 48. Grain size distribution at Whiteday Cherry Run Road (WD CHRY RD). Data from pebble count that was collected on $5 / 24 / 12$.

Figure 49. Grain size distribution at Whiteday Cherry Run Road (WD CHRY RD). Data from pebble count that was collected on $7 / 3 / 12$.

Figure 50. Grain size distribution at Whiteday Cherry Run Road (WD CHRY RD). Data from pebble count that was collected on $8 / 2 / 12$.

Figure 51. Grain size distribution at Whiteday Cherry Run Road (WD CHRY RD). Data from pebble count that was collected on $8 / 30 / 12$.

Figure 52. Grain size distribution at Whiteday Creek South (WDS). Data from pebble count that was collected on $8 / 2 / 12$ and $8 / 30 / 12$.

Figure 53. Grain size distribution at Downstream Reservoir (Ds Res). Data from pebble count that was collected on $5 / 24 / 12$.

Figure 54. Grain size distribution at Downstream Reservoir (Ds Res). Data from pebble count that was collected on $7 / 3 / 12$

Figure 55. Grain size distribution at Downstream Reservoir (Ds Res). Data from pebble count that was collected on $8 / 2 / 12$.

Figure 56. Grain size distribution at Downstream Reservoir (Ds Res). Data from pebble count that was collected on $8 / 30 / 12$.

Figure 57. Stream cross-section at Lick Run North (Lck N). Cross-section is illustrated as an upstream view from sampling location.

Figure 58. Stream cross-section at south Lick Run (S Lck). Cross-section is illustrated as an upstream view from sampling location.

Figure 59. Stream cross-section at Reservoir (Resv). Cross-section is illustrated as an upstream view from sampling location.

Figure 60. Stream cross-section at Laurel Run Southeast (Lrn SE). Cross-section is illustrated as an upstream view from sampling location. 
Figure 61. Stream cross-section at South Laurel Run ( S Lrn). Cross-section is illustrated as an upstream view from sampling location.

Figure 62. Stream cross-section at Whiteday Creek Cherry Run Road (WD CHRY RD). Cross-section is illustrated as an upstream view from sampling location.

Figure 63. Stream cross-section at Whiteday Creek South (WDS). Cross-section is illustrated as an upstream view from sampling location.

Figure 64. Stream cross-section at Downstream Reservoir (Ds Res). Cross-section is illustrated as an upstream view from sampling location.

Figure 65. Solinst continuous levelogger conductivity data for Resv over the duration of the monitoring period.

Figure 66. Solinst continuous levelogger temperature data for Resv over the duration of the monitoring period.

Figure 67. Solinst continuous levelogger water level data for Resv over the duration of the monitoring period.

Figure 68. Solinst continuous levelogger conductivity data for Lrn SE over the duration of the monitoring period.

Figure 69. Solinst continuous levelogger temperature data for Lrn SE over the duration of the monitoring period. Data points that abruptly equal zero are measurements that occurred when removing levelogger from site to download data.

Figure 70. Solinst continuous levelogger water level data for Lrn SE over the duration of the monitoring period. Data points that abruptly equal zero are measurements that occurred when removing levelogger from site to download data.....

Figure 71. Solinst continuous levelogger conductivity data for S Lrn over the duration of the monitoring period.

Figure 72. Solinst continuous levelogger temperature data for S Lrn over the duration of the monitoring period.

Figure 73. Solinst continuous levelogger water level data for S Lrn over the duration of the monitoring period.

Figure 74. Solinst continuous levelogger conductivity data for Ds Res over the duration of the monitoring period.

Figure 75. Solinst continuous levelogger temperature data for Ds Res over the duration of the monitoring period.

Figure 76. Solinst continuous levelogger water level data for Ds Res over the duration of the monitoring period. 


\section{List of Tables}

Table 1. Comparison of Vertical vs. Horizontal Drilling related to Impervious Surfaces ......................... 11

Table 2. National Research Center of Coal and Energy Analytical Laboratory Standards .......................23

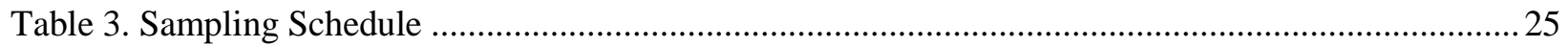

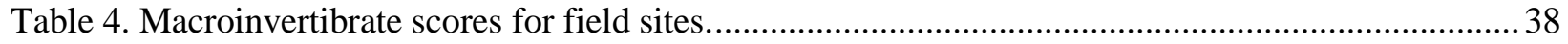

Table 5. NRCCE Lab analysis for the sampling sites located up and downstream of the pre-construction

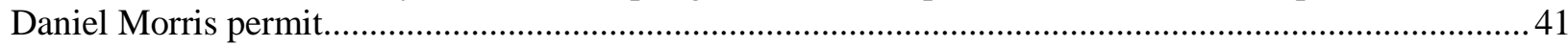

Table 6. NRCCE Lab analysis for the sampling sites located upstream of the active Edwin Bunner permit.

Table 7. NRCCE Lab analysis for the sampling sites located downstream of the active Edwin Bunner permit.

Table 8. NRCCE Lab analysis for the sampling sites located up and downstream of the inactive Orthodox

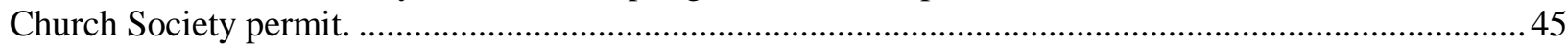

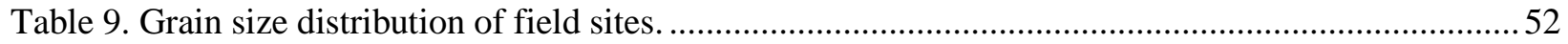

Table 10. Macroinvertibrate collection results from site 2 Lick Run North (Lck N). Macroinvertibrates

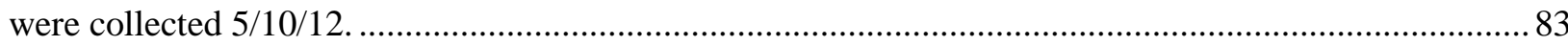

Table 11. Macroinvertibrate collection results from site 3 South Lick Run (S Lck). Macroinvertibrates

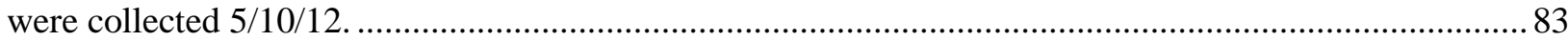

Table 12. Macroinvertibrate collection results from site 4 Reservoir (Resv). Macroinvertibrates were collected 5/10/12.

Table 13. Macroinvertibrate collection results from site 5 Laurel Run Southeast (Lrn SE). Macroinvertibrates were collected 5/10/12.

Table 14. Macroinvertibrate collection results from site 6 South Laurel Run (S Lrn). Macroinvertibrates were collected $5 / 10 / 12$.

Table 15. Macroinvertibrate collection results from site 7 Whiteday Cherryrun Road (WD CHRY RD).

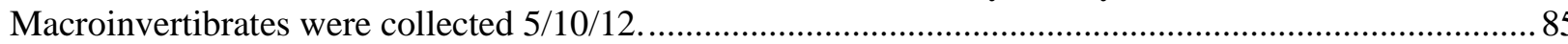

Table 16. Macroinvertibrate collection results from site 9 Downstream Reservoir (Ds Res). Macroinvertibrates were collected 5/10/12. 


\section{Ch. 1 Introduction}

One of the most desired shale gas fields for production is the Marcellus shale in the eastern U.S. This shale layer is estimated to contain 50 trillion cubic feet of recoverable gas (Engelder and Lash 2008); however, as the development of natural gas has expanded into the Marcellus shale there are serious concerns regarding the potential environmental impacts that are associated with this development. One concern is the impact it may have on water quality. Water is a key component in the production of natural gas. Natural gas is extracted from the shale layer by hydrofacturing. Hydrofracturing is the process that uses 3-5 million gal of a pressurized water mixture to fracture the shale rock, which creates small fissures for the natural gas to flow from and to the surface (Veil 2010). However, before the natural gas is collected at the surface, $20 \%$ to $40 \%$ of the water used to hydrofracture the shale will return to the surface as flowback water (Schramm 2011). This water contains concentrated doses of harmful constituents such as sodium, chloride, bromide, arsenic, barium, and other heavy metals (Soeder and Kappel 2009).

The concerns of water quality arise when this water is stored onsite or transported to municipal treatment facilities for disposal. What happens if the water from the onsite storage ponds begin to leak and enter nearby stream? Or can municipal treatment facilities treat the concentration of the flowback water? With the concern of the general public, local, state, and federal agencies regarding shale gas production and water quality, there is a need to know the risk associated with developing Marcellus shale.

The research presented in this thesis provides a detailed water quality analysis of streams that are located in close proximity to Marcellus shale drilling sites. A water quality monitoring plan was implemented in the Whiteday Creek watershed, West Virginia.

\subsection{Objectives}

The main objective of this research is to build the scientific understanding and assessment tools necessary to develop the confidence that key domestic oil and gas resources can be produced safely and in an environmentally sustainable way. Major tasks completed include the following:

Task 1: Design a monitoring plan to assess the surface water impacts of drilling for gas in the Marcellus Shale. 
Task 2: Complete surface water monitoring of paired reaches impacted by a Marcellus Shale drilling operation.

Task 3: Assess surface water quality impacts of drilling for gas in the Marcellus shale.

\subsection{Summary of study design}

This research assessed impacts of drilling for gas in the Marcellus shale in the White Day Creek watershed in northern West Virginia. A total of eight stream sites, located both upstream and downstream of three permitted gas wells, were monitored. Two of the permitted wells were in the development phase while the third was actively being drilled. Conductivity, $\mathrm{pH}$, turbidity and temperature were measured bi-weekly at each sampling site. Benthic macroinvertebrate communities were also monitored and rated using the West Virginia Stream Condition Index (WVSCI). Physical characteristics within the watershed were measured through pebble counts and cross sectional surveys. Continuous monitors were installed at the four sites surrounding the active drill site measuring conductivity, temperature, and stage. Water samples were collected during the bi-weekly sampling and analyzed at the National Research Center of Coal and Energy Analysis Laboratory. 


\section{Ch. 2 Literature Review}

\subsection{Marcellus Development}

A unique rock formation that contains large amounts of natural gas is the Marcellus Shale, located in the northeastern United States. The Marcellus Shale was formed 360-390 million years ago in the middle to upper Devonian of the Appalachian basin. It is a thick layer, (30-50 m), of classic sedimentary rocks that was transported from present day New England through a process called glacial till. The Marcellus Shale extends from the southern tier of New York, half of Pennsylvania, most of West Virginia, and sections of western Maryland, Virginia, eastern Ohio, and southern Ontario (PSU 2010).

The depth of the Marcellus Shale formation was a limiting characteristic for extraction. The shale layer ranges in depth of 5,000-8,000 ft in depth below the earth's surface in New York, Pennsylvania, and West Virginia (PSU 2010). In Ohio and southwestern New York, the shale layer sustains approximately 2,000 ft below the earth's surface. The Marcellus Shale acquires several trillion cubic feet of natural gas. In 2006, the United States Geological Survey (USGS) estimated the recoverable gas to be 2 trillion $\mathrm{ft}^{3}$. However, Engelder and Lash (2008) estimated the Marcellus Shale to contain 50 trillion $\mathrm{ft}^{3}$ of recoverable gas.

Natural gas is traditionally obtained by vertical drilling. The technique of vertical drilling is not feasible in the Marcellus Shale because the natural gas captured is confined to the area around the bore hole. The most productive way to mine for natural gas is directional drilling. Directional drilling or horizontal drilling is the process of drilling a well vertically into the crest of the earth, then turning the drill bit about a proposed curve to create a bore path parallel to the earth's surface (Helms 2008). This idea, introduced by John Smalley Campbell in 1891, was placed into practice during 1929 in Texas. In 1944, Pennsylvania drilled a 500-ft deep directional well used to mine oil. China and the Soviet Union experimented with the idea in the 1960's with little success. In the early 1980's, horizontal drilling became economical due to the advancement of the downhole drilling motor and the invention of downhole telemetry equipment.

In the past, the cost of directional drilling made it economically unfeasible to drill Marcellus Shale, compared to the preferred technique of vertical drilling; however, with increased oil prices and technological advancements, directional drilling Marcellus Shale became more economical and efficient per drill site. In 2005, Pennsylvania drilled the first complete horizontal well into the Marcellus Shale (Soeder 2010). 
Natural gas is retrieved through the hydraulic fracturing process. Hydraulic or "slickwater" fracturing is a process where a volume of pressurized water mixture of sand and chemicals are injected into the bore hole to fracture the shale. Approximately 3-5 million gallons of this water mixture is used in each fracturing stage. After the fracturing occurs, the sand in the water mixture fills the fractured areas and creates channels for the natural gas to escape. Before the natural gas can be recovered, some of the water mixture is extracted out of the hole. Approximately twenty to thirty percent of the initial water mixture is recovered. This returning water is known as "frac" water.

The use of "frac" water raises environmental concern because additional constituents are introduced to the water during the fracturing process. When the "slick-water" mixture fills the pours and fractures of the shale layer, it absorbs the matter from the rock formation. As the hydrofrac water returns to the surface it may contain formation material, including brines, heavy metals, radionuclides, and organics which make wastewater treatment difficult and expensive (Soeder and Kappel 2009). There are often high concentrations of sodium, chloride, bromide, arsenic, barium, and other heavy metals that are found in the returning hydrofrac water. These concentrations usually exceed safe drinking water standards (Harper 2008). With the hazardous constituents found in the "frac" water, a concern arises about the proper treatment or disposal of the water mixture. "Frac" water has been treated or disposed in a variety of procedures: onsite treatment, hauling to wastewater treatment plants, injection wells approved by EPA, and recycling water back into new drill bores.

As the hydrofrac water is being treated or disposed of there are several other potential hazards associated with the drilling in the Marcellus shale: 1) increase impervious surfaces in a watershed; 2) potential water contamination from hydrofrac constituents; 3) the degradation of neighboring streams. However, there are several positive aspects for WV to drill in the Marcellus shale. In a time where the United States is in an economic recession, the opportunity to drill in the Marcellus shale will increase the job market in WV. Potentially 19,000 new job opportunities related to Marcellus shale drilling in West Virginia will occur by 2015 (Burdette 2011).

\subsection{Regulations related to surface water}

Regulations have been developed to help protect surface water from possible contamination. Regulations are applied to the development of shale gas from the federal, state, 
and local level of organizations and agencies. Current setback distances required in the state of WV include the following (WVDEP, 2012; Van Nostrand et al. 2012):

1. $250 \mathrm{ft}$ from any existing water well or developed spring used for human or domestic animal consumption. (WV Code $§ 22-6 \mathrm{~A}-12$ );

2. $625 \mathrm{ft}$ of a dwelling or large cattle or chicken shelter;

3. $100 \mathrm{ft}$ from any perennial stream, natural or artificial lake, pond or reservoir, or a wetland;

4. $300 \mathrm{ft}$ of a naturally reproducing trout stream; and,

5. 1,000 ft of a surface or ground water intake of a public water supply. Water management plans that reduce and prevent runoff are also required.

\subsection{Watershed Impacts}

\subsubsection{Impervious surfaces}

Impervious surfaces are the areas covered by material that impede the infiltration of water into the soil surface. Examples of impervious surfaces include buildings, pavement, concrete, and mechanically compacted soils. Impervious surfaces create an issue in the environment because they replace pervious areas, such as forested areas and wetlands, which would absorb and clean stormwater in the natural system (Carter 1961; Leopold 1968). As the absorption rate decreases the quality and quantity of storm water is affected. The quality of storm water will decrease because soil acts as a natural filter.

Likewise, there will be an increase in the quantity of stormwater due to the lack of pervious material to absorb the stormwater. This change in the landscape can have environmental impacts that progress into stream and watershed systems. The quality and quantity of storm water are directly related to the amount of impervious to pervious surfaces in a watershed. Schuler (1994) summarized eleven studies and concluded that stream quality declines at value of 10\%-15\% imperviousness. Brabec et al. (2002) classified stream health in three categories related to impervious coverage; protected is less than $10 \%$ impervious area, impacted is between $10 \%$ and $30 \%$ impervious area; and, degraded is $30 \%$ or more impervious area.

At the simplest level, stream hydrology and function are dependent on five variables: climate, geology, soils, land use, and vegetation (Laflure and Morisawa 1979). Of the five 
variables, land use and vegetation are the only two that humans can alter or impact. When a development to a watershed occurs there is an increase in impervious surfaces, which changes the land use and decreases the amount of pervious surfaces. Also, when these variables are altered, it affects the quality of a stream. Stream quality is a combination of the physical, chemical, and biological health of a stream (Brabec et al. 2002).

One of the most prominent sources of stream degradation is the increase to storm water runoff. When runoff rates increase there are significant changes to stream and watershed properties. Storm water has the potential to erode and transport sediment towards natural streams that are located at the lower elevations. This sediment could contain concentrated levels of minerals and other contaminants that could degrade streams.

When considering the potential downfalls of impervious surfaces to a watershed it is also important to focus on the pervious surfaces that are being replaced in the area. Pervious surfaces in a watershed increase infiltration and evaporation due to the vegetation and soil storage of water. However, as the percent of imperviousness increases, so does the amount of runoff that result from a rain event. There is also a decrease in evaporation, transpiration, and infiltration of the rain event. Potential watershed outcomes related to increase in impervious surfaces include the following (Arnold et al. 1996; Arnold et al. 1982; Galli 1992 Schueler 1992):

- reduction of ground water recharge, stream base flow, and water tables;

- increased erosion and peak flows;

- increase in nutrient concentrations;

- fish kill;

- increased transportation of heavy metals;

- increased volume of water and sediment;

- loss of streamside and in-stream habitat; and,

- increase/decrease in water temperature.

To help evaluate how the needs for pervious surfaces in watershed assist in a reduction to storm water runoff volume, Ross and Dillaha (1993) performed a study which compared six different surface types. The study focused on runoff volumes, nutrient and sediment concentrations of suspended solids. Results indicated that there is significant importance for 
pervious surfaces in a watershed. Meadows and mulched landscapes absorbed the entire simulated rainfall event, whereas the surfaces that closely relates to an impervious surface, the gravel driveway, produced the most runoff volume. The gravel driveway also transported nutrient and sediment loads, which in real world situations, could meander to local streams. Disturbance in stream quality could occur in high rain event. When considering the properties of an impervious surface it can be expected that the volumes concluded in this experiment will be even greater.

\subsubsection{Roads}

One of concern with developing the Marcellus shale is the traffic that is associated with drilling. An increase in traffic will occur due to drilling requirements. Drilling requires large triaxle and semi-trucks to transport drilling operation equipment, storage tanks, and several trips to transport water on-site for fracturing purposes. For general gas drilling operations, Mitchell (2010) developed characteristics of truck traffic that is to be expected. The first characteristic is the number of trips required to construct a production well site. Each well site is expected to have approximately $890-1,350$ truck hauls. A truck haul is a trip to and from the well site. The next characteristic is the weight of each truck. These trucks average in hauling weight of $80,000+1 b s$. The final characteristic that was developed was relating truck traffic to typical car traffic. Mitchell (2010) formulated that the 890-1,350 truck hauls is equivalent to 3.5 million car trips.

From these statistics it can be assumed that there is a significant increase in vehicle weight, as well as an increase in the number of trips a road can experience. According to the National Bureau of Economic Research (2011), the average vehicle weight is between 3,000 and 4,000 lbs, which is 20 times lighter than trucks used for drilling a well site. The issues of the increase truck weight and traffic is that most drilling is taking place in rural areas on secondary roads. These roads are not designed to handle the $80,000+\mathrm{lb}$ loads that result from drilling mobilization. Thomas Gillespie (1993) determined that road damages can occur when a single axle with dual tires exceeds 20,000 lbs. Damage to the road way is first noticed by a "loading footprint" or slight rutting of the pavement surface, which eventually results into surface degradation. Once the surface is broken down the pavement can then be eroded away resulting in "pot-holes" and poor driving conditions. 
Road clearance for drilling traffic is also an issue of concern. The drilling of natural gas in the Marcellus shale is primarily located in the middle of rural WV, PA, NY, and OH. Most of these rural areas provide secluded home sites and offers limited transportation routes. Roads in these areas are difficult to design cost effectively due to the mountainous topography. However, with the movement of natural gas drilling into these areas, modifications to roadways frequently occur. The Unified Facilities Criteria (UFC) 2006 state that the minimal width of two lane roads in a mountainous region is about $20 \mathrm{ft}$. However, the minimal road width of a single lane road is 9-10 ft, which happens to be the condition in several drilling locations. With the presence of narrow roads, drilling companies have difficulty mobilizing equipment. For example, the Delta Oil Field Company designed frac tank trailers with an average width of $8.5 \mathrm{ft}$. These tanks nearly meet the minimal width of a single lane road, not to consider the trucks turning radius. This situation creates treacherous traffic conditions both for the company and residents. To ensure that this situation occurrence is minimal, companies are redesigning roads to meet width needs.

In addition to possible road damages, roads are being modified to account for clearance issues related to drilling traffic. Construction of roads in mountainous terrain requires a design process called cut-and-fill slopes. A cut, or the removal of material, is performed on the slope and that material is then placed on the downward facing slope of the cut creating a flat road surface. Most secondary roads are constructed at a max cutslope of $30-45^{\circ}$ angle to roadway surface to minimize the width of the property required for construction (Megahan et al 2001).

Detrimental impacts may develop in watersheds with the widening or construction of roads. Trombulak and Frisell (2000) identified seven effects of roads: modified animal behavior, changes in physical geography such as surface runoff, erosion, sedimentation effect on aquatic/terrestrial animals, changes in wildlife population due to direct kills, edge effects, spread of exotic species, and increase human ecological impacts. When considering the different effects that occur due to road construction, hydrology is altered by the slightest degree of change.

Construction of roads changes the hydrology of an area by routing water through new channels, disturbing and eroding soils, and creating new impermeable surfaces that divert runoff to smaller areas of infiltrations and absorption (Jones et al. 2000). Infiltration is important because it recharges groundwater to support streams, gives soil a moisture content to provide stability and prevent erosion, and decreases the amount of runoff reducing floods in river valleys (Manning 1997). 
Roads concentrate flows and increase velocities of these flows. Montgomery (1994) and Forman and Alexander (1998), state that the increase flows can elongate low-order sub-basins, and increase the effective length of a stream channel. With the increase in velocity, infiltration decreases resulting in a rise in the runoff volumes. Wemple et al. (1996) stated that the alternation and concentration of flow from roads can cause formation of new drainages, as well as diversions and changes to the hydrology of the water basins.

\subsection{Phase of Development}

When developing the Marcellus shale for natural gas there are steps that must be followed to reach an efficient producing well: leasing land, well placement, drilling/construction of wells and pipe lines, and finally reclamation. To establish a producing well a drill pad must be constructed. Construction on the drill pad starts by clearing and grubbing the vegetation and woody debris from the site (DOE 2009). Next, the site is leveled and a berm is created around the perimeter of the site. Inside the bermed area, a thick piece of plastic is placed underneath a layer of compacted stone or soil as a protective barrier. The next phase of development to a drill pad is the placement of an onsite drilling rig. A drill rig is designed to be a mobile structure which can be used on multiple drill sites. While drilling, a larger steel pipe is cemented into the bore hole. The pipe seals the bore hole and protects the groundwater from fluids used in drilling that could lead to possible contamination (Considine 2009).

Drilling will continue to a designed depth that is relatively close to the shale layer. At this point, the driller then begins to turn the bit until it creates a horizontal bore path or leg. The horizontal leg will continue through the shale layer and will be drilled for several thousand feet. This horizontal leg creates the opportunity for larger extractions of natural gas without the addition of multiply drill site (DOE 2009). However, with an increase in natural gas production when comparing horizontal to vertical wells, the cost to drill a horizontal well is 3-4 times more than that of a vertical well. After the reaching the end of the drilled hole, the drilling rig will be removed from the pad and a wellhead will be placed to cap the drilled hole. A wellhead allows for the control of the insertion or extraction of fluids and gases from the well.

Before natural gas can be extracted, a sequence of explosions occurs in the horizontal leg, which is designed to fracture the bore hole casing. Fracturing the horizontal legs enables a company for perform a procedure called hydrofracturing. This procedure injects several million gallons of pressurized water mixture into the drilled hole. The water mixture contains sand and 
other additives that causes the water to become "slick". This pressurized water mixture is forced through the shale layer causing fracturing to occur. The sand in the water mixture is forced into the shale allowing the fissures to remain open and the natural gas to flow from the shale into the bore hole. This process enables companies to extract larger volumes of natural gas (Considine 2009). A concern for companies and individuals is the one-third of the hydrofracturing fluid that returns to the surface. This water contains high concentrations of alkalinizes and other ions that could have harmful environmental impacts. To minimize this concern companies implement water containment plans. These usually consist of two onsite designs, containment ponds or storage tanks. Containment ponds are lined with a thick plastic and are open to the environment. Since the water is exposed to the environment it allows for most of the water to be evaporated and to leave behind the slurry of hazardous materials that is to be treated for disposal. Storage tanks are large metal containers that hold approximately 18,000-21,000 gallons of fluid (Delta Oil Field Company). These tanks are placed closely together to maximize storage and minimize area on the pad. To dispose of fluids, the tanks are transported to treatment facilities that can treat the concentration levels of the frack fluid, landfills, and EPA approved injection sites.

After the well is drill, fractured, and flowback water is captured, reclamation and production of the well occurs. Reclamation is to take the drill pad from the drilling phase and return it to its natural phase before drilling. This is completed by the use of heavy equipment to remove onsite storage ponds, drilling structures, and to place topsoil over the drilling site. Topsoil is then blended to the natural topography. Native grasses are planted to provide quick vegetation to help with erosion control. The final site will have a well head, regulator, and a graveled road to site minimizing the amount of impervious surfaces (Considine 2009).

\subsection{Well density}

One potential land use change resulting in response to this shale development is the increase in impervious surface area due to converting rural land use to well pads. Drilling in the Marcellus shale does add several impervious surfaces in order to operate the system. These surfaces include drill pads, storage containers, buildings, and access roads. Drill pads are large, relatively flat, areas that must accommodate drilling rig, compressor, pumps, drilling pipes and rack, and often a small shelter for operation employees. Drill pads can vary in size depending on the type of drilling that is performed. Vertical well drill pads have an approximate area of 2 ac 
plus an additional 2.7 ac of other impervious surfaces, mainly consisting of roads. Horizontal well drill pads have an average of 4 ac with an additional 3.4 ac for roads (Arthur 2010 and DOE 2009). Table 1 displays the differences in drill spacing, drill pad size, vertical drilling, and horizontal drilling related to impervious surfaces.

Horizontal drilling is more efficient in extracting natural gas when compared to vertical drilling. Nearly 640 ac can be drained from one horizontal drilling pad, while it would take 16 individual vertical drill sites to drain the same area (Arthur et al. 2008, NETL 2010, and Veil 2010). To further support the advantage of horizontal drilling recent production analysis concluded that the drainage area of a vertical drill site is not $40 \mathrm{ac}$, instead the effective drainage area is only 10 to 20 ac (Veil 2010; Table 1). This results in half of the natural gas being extracted (NETL 2009), thus defaulting modern drilling practices to horizontal drilling.

Table 1. Comparison of Vertical vs. Horizontal Drilling related to Impervious Surfaces

\begin{tabular}{ccccc}
\hline & $\begin{array}{c}\text { Vertical } \\
\text { Drilling }\end{array}$ & Reference & $\begin{array}{c}\text { Horizontal } \\
\text { Drilling }\end{array}$ & Reference \\
\hline $\begin{array}{c}\text { Drill Spacing } \\
\text { (ac) }\end{array}$ & 40 & Parshall (ND) & 160 & Arthur et al. (2008) \\
& & DOE (2009) & & DOE (2009) \\
& & NETL (2009) & & Veil (2010) \\
& & Veil (2010) & & Arthur (2010) \\
& & Arthur (2010) & 4 & DOE (2009) \\
\hline $\begin{array}{c}\text { Drill Pad Area } \\
\text { (ac) }\end{array}$ & 2.1 & DOE (2009) & 3.5 & DOE (2009) \\
\hline $\begin{array}{c}\text { Drilling Roads } \\
\text { (ac) }\end{array}$ & 2.0 & Arthur (2010) & 3.4 & Arthur et al. (2008) \\
Number of Wells & 16 & Arthur et al. (2008) & $4-6$ & Veil (2010) \\
(per 640 ac) & & NETL(2010) & & Arthur (2010) \\
& & Veil (2010) & & DOE (2009) \\
\hline $\begin{array}{c}\text { Impervious Area } \\
\text { (per 640 ac) }\end{array}$ & 77 & Arthur (2010) & 7.4 & DOE (2009) \\
$\begin{array}{c}\text { Percent } \\
\text { Impervious area } \\
\text { (per 640 ac) }\end{array}$ & 12 & Arthur (2010) & 1 & \\
\hline
\end{tabular}

\subsection{Water quality parameters}

Water quality is determined by the "goodness" of water for particular purposes (McCaffrey 2011). This project focuses on the water quality of surface water. To ensure that water quality is maintained, the Clean Water Act of 1972 has developed water quality standards 
and parameters for the diverse characteristics that water can retain. The following paragraphs expand on several components of water that this project monitored.

\subsubsection{Temperature}

Temperature is the degree of coldness or hotness of the water. Temperature is important to monitor because it can affect the level of dissolved oxygen present in water. Water that is at lower temperatures possesses more dissolved oxygen compared to that of water with higher temperatures. For example water at $10^{\circ} \mathrm{C}$ can retain up to $11.29 \mathrm{mg} / \mathrm{L}$, while water at $25^{\circ} \mathrm{C}$ can retain $8.26 \mathrm{mg} / \mathrm{L}$ (McCaffrey 2011). Water must contain so much dissolved oxygen to provide aquatic life with the required amount of oxygen to survive. Also, if dissolved oxygen is depleted a possible algae bloom out break could occur endangering the entire stream by absorbing the remaining dissolved oxygen. The WV Department of Environmental Protection (WVDEP) has set standards and limits for temperature. The WVDEP manual 47CSR2 parameter 8.29 states,

"Temperature rise shall be limited to no more than $5^{\circ} \mathrm{F}$ above natural temperature, not to exceed $87^{\circ} \mathrm{F}$ at any time during months of May through November and not to exceed $73^{\circ} F$ at any time during the months of December through April. During any month of the year, heat should not be added to a stream in excess of the amount that will raise the temperature of the water more than $5^{\circ} F$ above natural temperature." (WVDEP 2011)

These limits can vary due to stream or river location and its natural characteristics.

Limits are determined to help protect plants, animals, and aquatic life from endangerment. Life cycles of aquatic life are often related to temperature change. If temperatures above $78^{\circ} \mathrm{F}$ were to exist for a period of time in the month of February it could have an effect on the aquatic life that would be present in the streams that spring. Temperature of water is important to be monitored since it can have a negative influence on a streams overall health. It can be measures by the use of thermometers or temperature probes.

Marcellus shale development can alter water temperature by increased runoff rates that can result from additional impervious surfaces required for drilling. Also, clearing trees and vegetation around streams for development reduces the amount of shade over the stream, which results in higher temperatures. 


\subsection{2 $\mathrm{pH}$}

By definition $\mathrm{pH}$ is the measure of acidity or alkalinity of water (McCaffrey 2011). It is important to monitor $\mathrm{pH}$ because aquatic organisms can only live in certain $\mathrm{pH}$ levels. Most fresh water fish live in $\mathrm{pH}$ levels between 6.5 and 8.4, while water with a $\mathrm{pH}$ less than 4.8 or greater than 9.2 can be harmful to aquatic life (Goeken et al. 2004). The WVDEP manual 47CSR2 states that $\mathrm{pH}$ values may not exceed the range of 6.0 to 9.0 unless influenced by photosynthetic activity (WVDEP 2011). Several naturally occurring conditions can influence $\mathrm{pH}$. A waters $\mathrm{pH}$ may have an acidic value, $\mathrm{pH}$ range of 0 to 6.9 , if soils and runoff around water are acidic. Granite and sandstone can contribute to lower a streams pH (McCaffrey 2011). Limestone, fertilizers, and detergents can result in an alkaline $\mathrm{pH}$, between the range of 7.1 to 14 . It can be monitored or checked be the use of litmus paper or a digital $\mathrm{pH}$ electrode.

Marcellus shale development can affect $\mathrm{pH}$ if an acidic or alkaline concentration from the flow back water enters the stream. Acidic concentrations will lower the $\mathrm{pH}$ below neutral 7 , while alkaline concentrations increase $\mathrm{pH}$ above neutral 7 (EPA 2001). Also, pH can also be altered by geological features. Limestone soils or roads lined with limestone gravel can cause $\mathrm{pH}$ to become more basic (Nord and Mortensen 2010).

\subsubsection{Turbidity}

Turbidity is the measurement of water clarity or how far light can travel through water (Goeken et al. 2004). As particles, both organic and inorganic, become suspended in the water column, the more difficult it is for light to travel through the water. The more suspended particles that is present in water the more cloudy the water becomes, resulting in a higher turbidity. A higher turbidity also lowers the photosynthetic activities that should be present in the water resulting in the decay of submerged plants. Another issue with an increased turbidity is its relationship to water temperature. As turbidity increases so can the water temperature, which previously discussed can result in unsafe stream conditions for aquatic life (McCaffrey 2011).

The WVDEP parameter for turbidity is measured in Nephelometric Turbidity Units (NTU). Each stream has an average or background turbidity that was formulated from previous water sampling results. If the background turbidity is less than $50 \mathrm{NTU}$ 's, the limit is set to be no more than 10 NTU's above the background turbidity. If the background turbidity is greater than 50 NTU's, then the limit is set to the back ground turbidity plus a $10 \%$ increase with a minimum of 10 NTU's (WVDEP 2011). 
Marcellus shale development can increase turbidity by increased runoff rates that are associated with shale development. Increased runoff has the potential to transport silt and clay particles to neighboring streams, which increase turbidity (MPCA 2008). As water levels fall in the summer months, turbidity can greatly increase with a large sediment deposit into the stream.

\subsubsection{Conductivity}

Conductivity is a physical property of a substance determined by how well it can conduct an electrical current. Conductivity is directly related to the concentration of dissolved solids in water (McCaffrey 2011). Total dissolved solids can be closely estimated based on conductivity. Dissolved solids that affect conductivity is inorganic dissolved solids such as chloride, nitrate, sulfate, and phosphate anions or sodium, magnesium, calcium, iron, and aluminum cations (EPA 2012). Also the warmer temperatures can also elevate waters conductivity. Warmer temperatures may cause an increase in ions due to dissociation of molecules (Barron and Ashton 2005). Therefore, water in the summer months generally has a higher conductivity than the winter months (McCaffrey 2011).

Conductivity is measured in units of microsiemens per centimeter $(\mu \mathrm{S} / \mathrm{cm})$ or micromhos per centimeter $(\mu \mathrm{mhos} / \mathrm{cm})$. Even though conductivity can be represented in two different units there is no difference in the numerical value. Most streams and rivers have conductivity between the range of 50 to $1500 \mu \mathrm{S} / \mathrm{cm}$ (EPA 2012). However, aquatic life thrives in water conditions where the conductivity is between the range of 150 to $500 \mu \mathrm{S} / \mathrm{cm}$. If conductivity exceeds 500 $\mu \mathrm{S} / \mathrm{cm}$ conditions for aquatic life become unsuitable (Goeken et al. 2004). The EPA has designated a conductivity benchmark of $300 \mu \mathrm{S} / \mathrm{cm}$ for streams in Central Appalachian (EPA 2011). The report released by the EPA discovered loss of macroinvertibrates at conductivity measurements higher than $300 \mu \mathrm{S} / \mathrm{cm}$.

Marcellus shale development has the potential to alter conductivity. Increased runoff rates associated with shale development influence conductivity. If runoff were to flow through limestone graveled roads created for drilling or transport loose soil particles to the stream, conductivity would increase (Nord and Mortensen 2010). Also, conductivity can change if flowback water was to enter the stream. Conductivity is directly affected by ion concentrations of sulfate, sodium, calcium, and chloride (EPA 2011). These ion concentrations are predominant in flowback water. 


\section{Ch. 3 Methodology}

The overall objective of this research is to assess the environmental impacts of drilling for gas in the Marcellus Shale, focusing on water resources. This chapter describes the watershed and outlines the monitoring and analysis procedures.

\subsection{Sampling Procedures}

\subsubsection{Watershed description and sampling locations}

Whiteday Creek Watershed was selected for study (Figure 1). This watershed is in close proximity of West Virginia University (within $20 \mathrm{mi}$ ) and has no coal mining within the watershed boundary. Within the watershed there are currently five different permitted natural gas drill sites. Since the study has begun there has been an additional three sites permitted in the southernmost part of the watershed. Figure 1 displays the well and monitoring locations. Nine different locations were selected (Figure 1). To decide the location of each monitoring site, ArcExplorer and field observations were conducted to decipher the best upstream and downstream locations of the permitted drill site. Upstream sites acted as a control, while the downstream sites were expected to monitor water that had the potential to be altered.

The first site is close to the mouth of the watershed located on Whiteday Creek. This sampling is being performed by West Virginia Water Research Institute as part of the Mon River QUEST project (West Virginia Water Research Institute 2012). This site was selected due to the existing data available (e.g. discharge and water quality data). This data will provide a prenatural gas exploration baseline. Two monitoring sites (S Lck and Lck N) were located on Lick Run in the western part of the watershed around the Daniel Morris permit (API \# 049-02190, 049-02173). S Lck is located upstream of the permit location, which is designated as a control monitoring site. Lck $\mathrm{N}$ is located downstream of permit location to monitor runoff volumes from drilling site. Both sites also provided a baseline flow due to no progression in preliminary construction required to begin the drilling process (Figure 2-3). A group of four monitoring sites (Lrn SE, S Lrn, Resv, and Ds Res) were located on Laurel Run around the Edwin Bunner Permit (API \# 049-02108, 049-02110, 049-02141, 049-02119), an active well site (Figures 4-7). Lrn SE and S Lrn were established upstream of the permit location as control sites. Resv was placed downstream of permit location to monitor stream water quality. Ds Res was placed downstream 
of Resv because of a reservoir located between both sampling sites. These four sites also have continuous monitors placed to provide real-time data. The final two monitoring sites (WDS and WD CHRY RD) were located at the southern part of the watershed on Whiteday Creek around the Orthodox Society Permit (API \# 091-01264, 091-01265, 091-01266, 091-01267, 091-01268, 091-01269; Figures 8-9). WDS was placed upstream of permit location to obtain control measurements, while WD CHRY RD was placed downstream of permit to monitor stream water quality that is influenced from drill site runoff. Data from this permit also provided baseline data since well development was inactive.

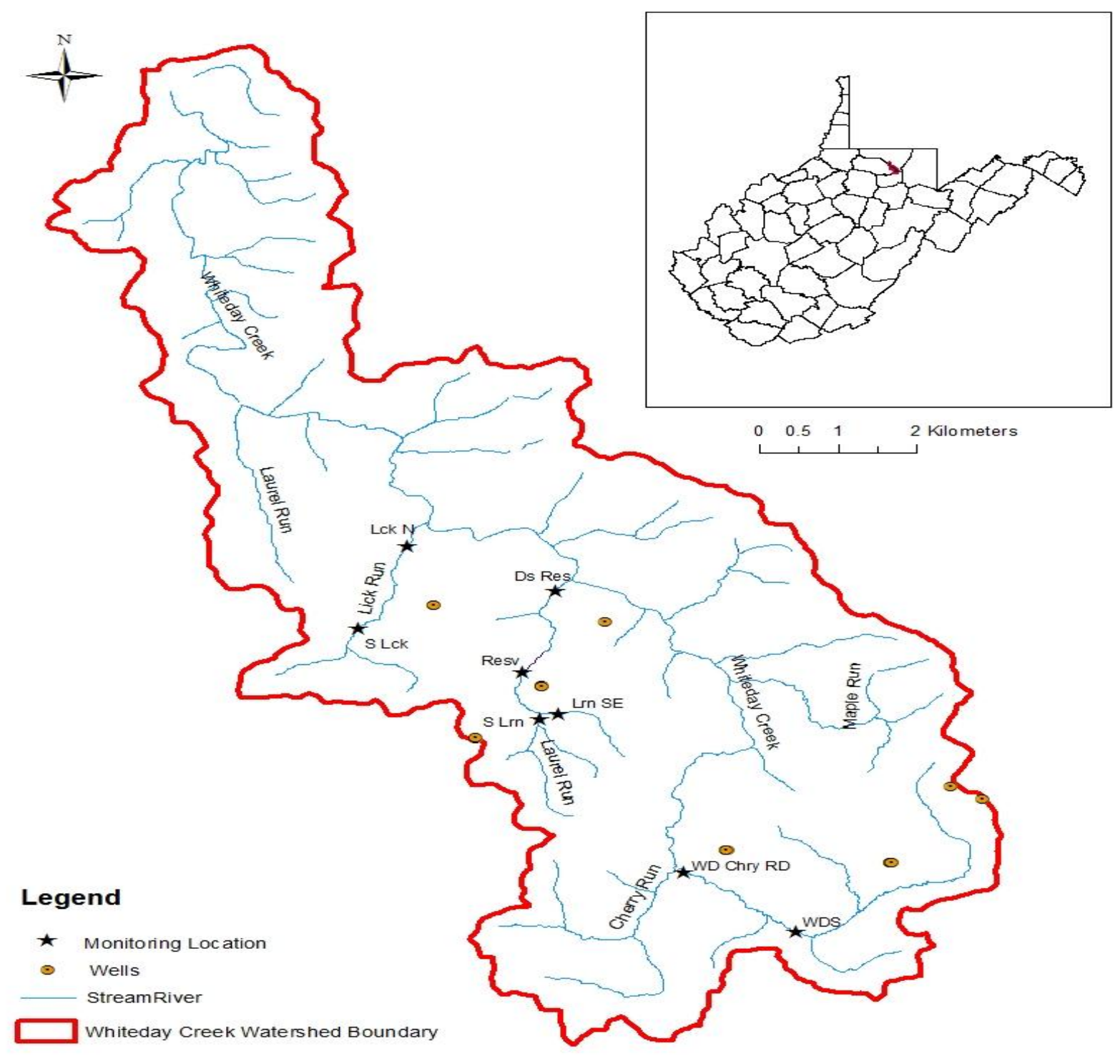

Figure 1. Whiteday Creek Watershed, depicting well and monitoring locations 


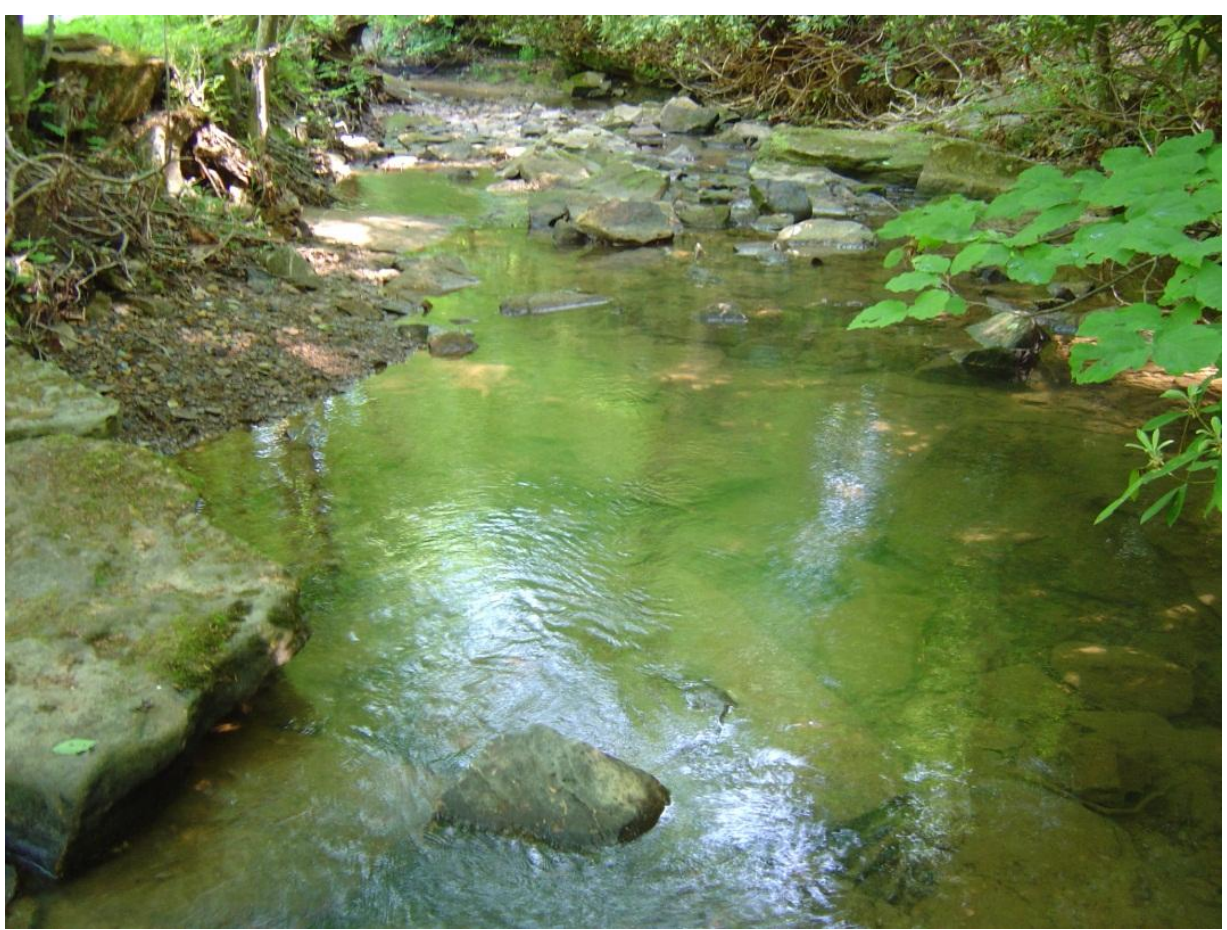

Figure 2. Lick Run North (Lck N)

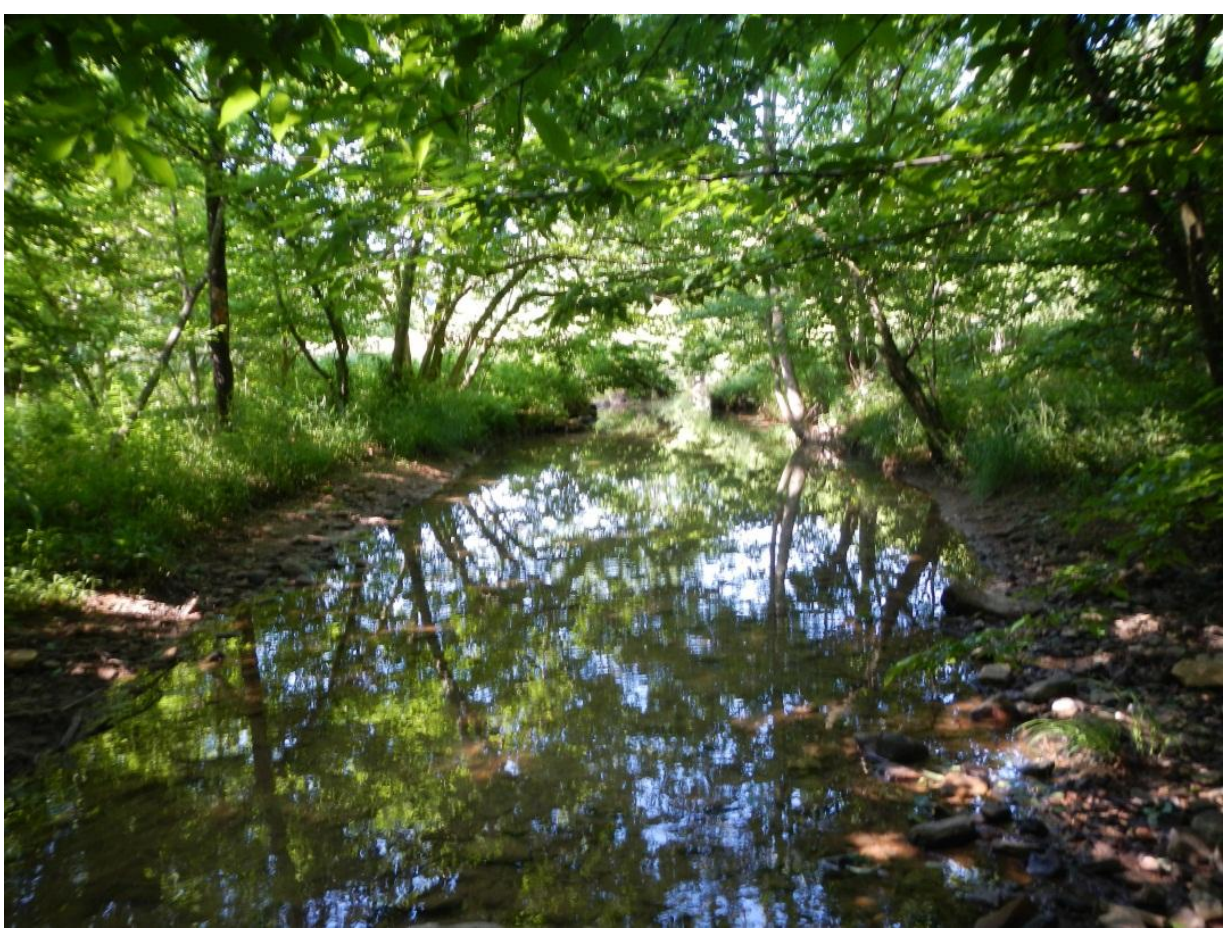

Figure 3. Lick Run South (S Lck) 


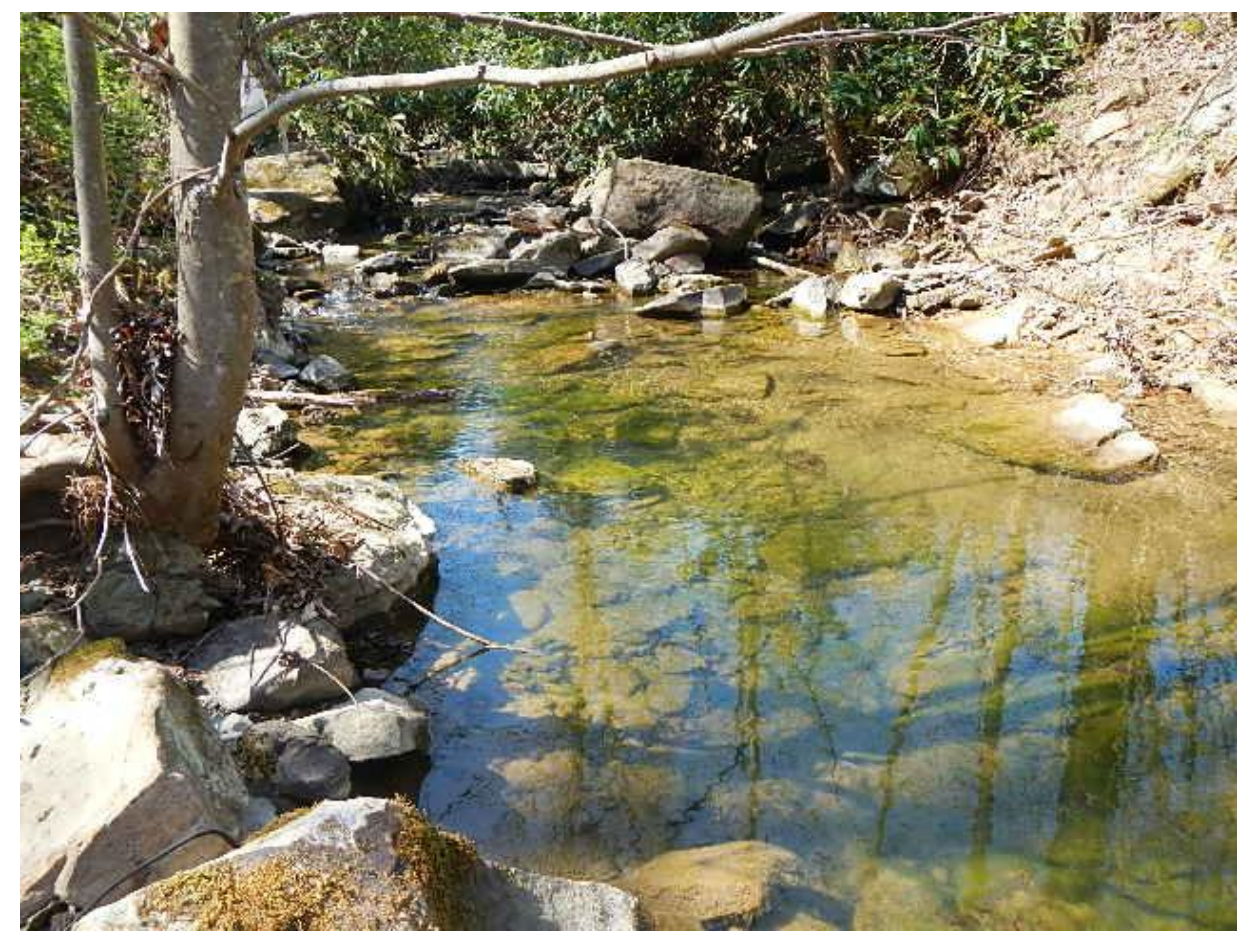

Figure 4. Downstream of Reservoir (Ds Res)

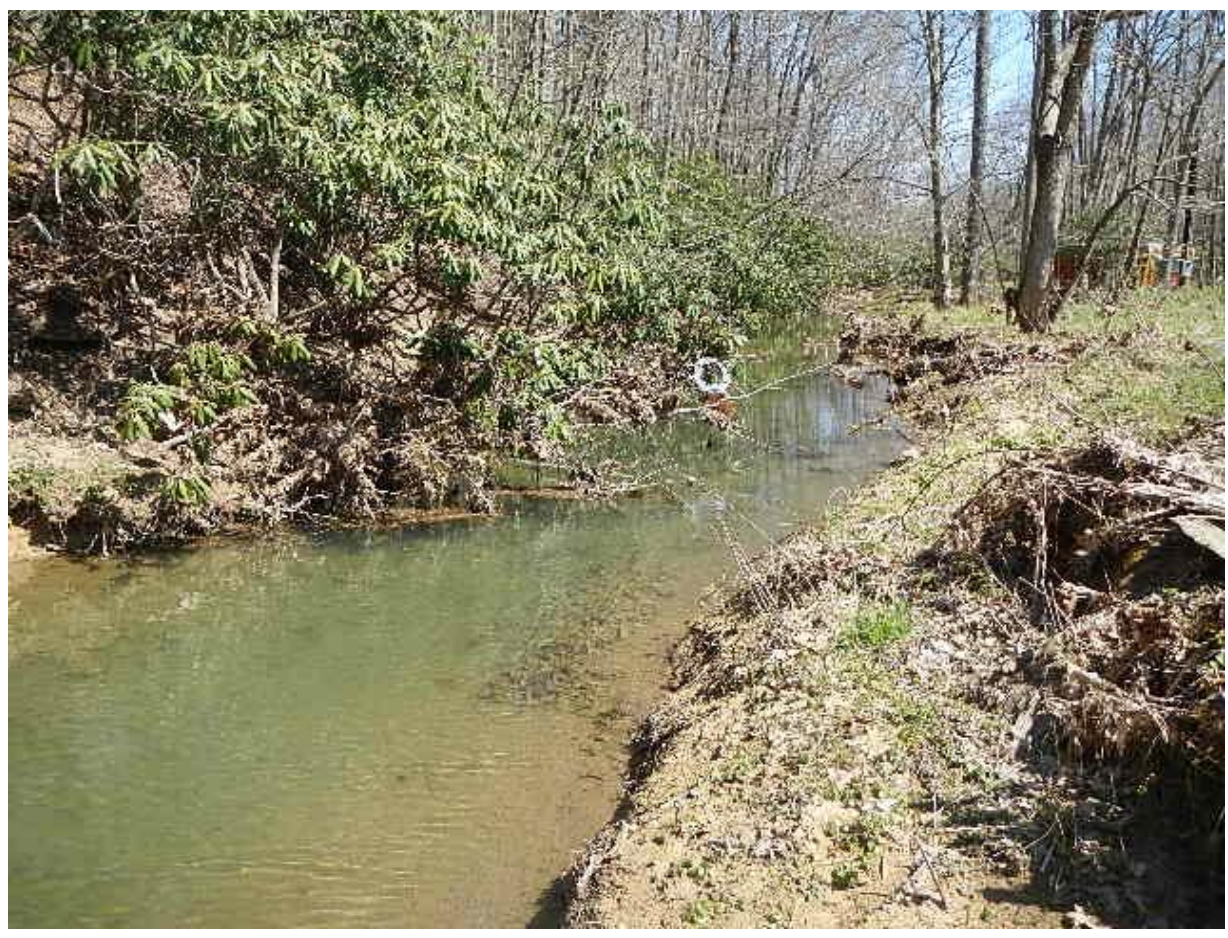

Figure 5. Reservoir Head (Resv) 


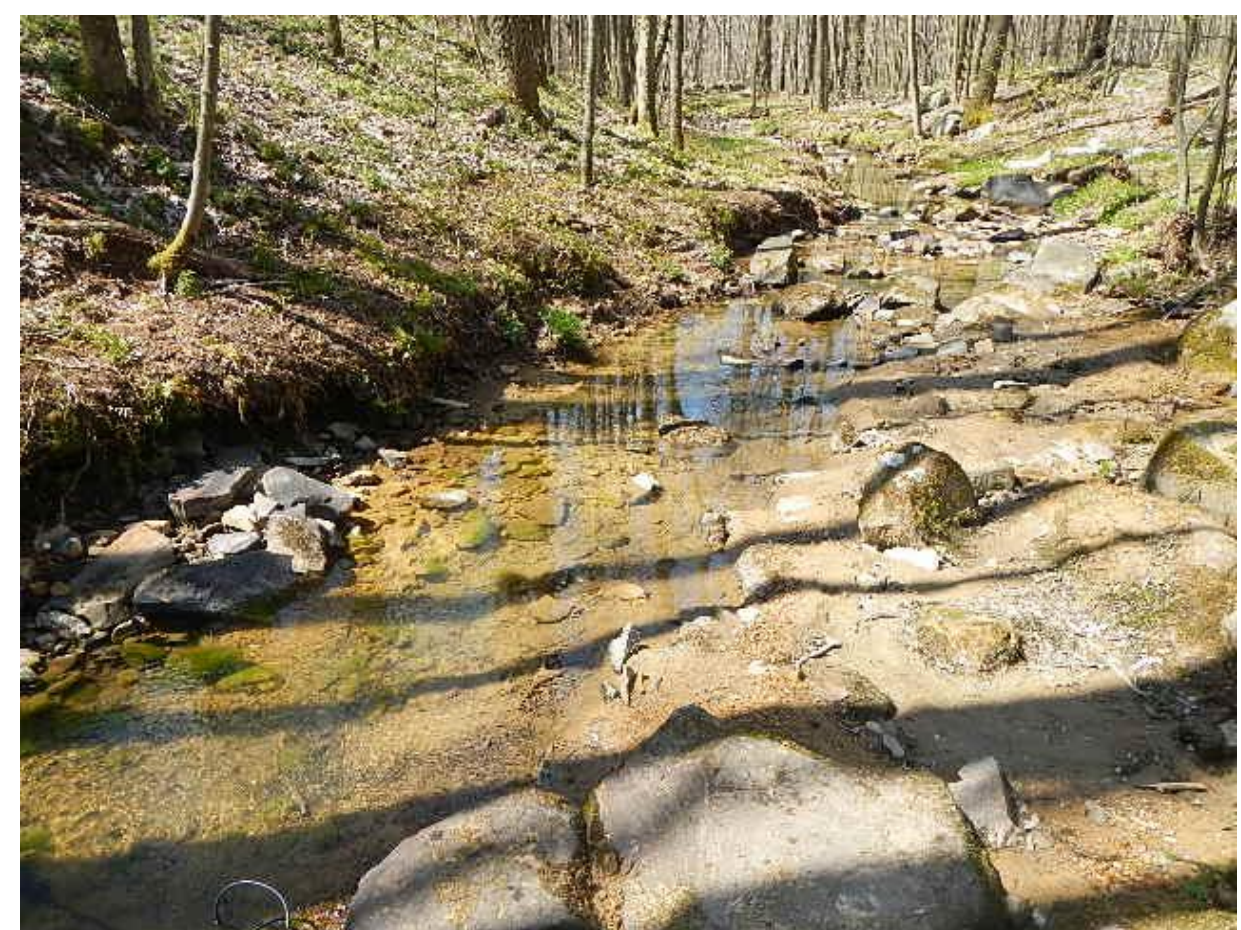

Figure 6. Laurel Run SE (Lrn SE)

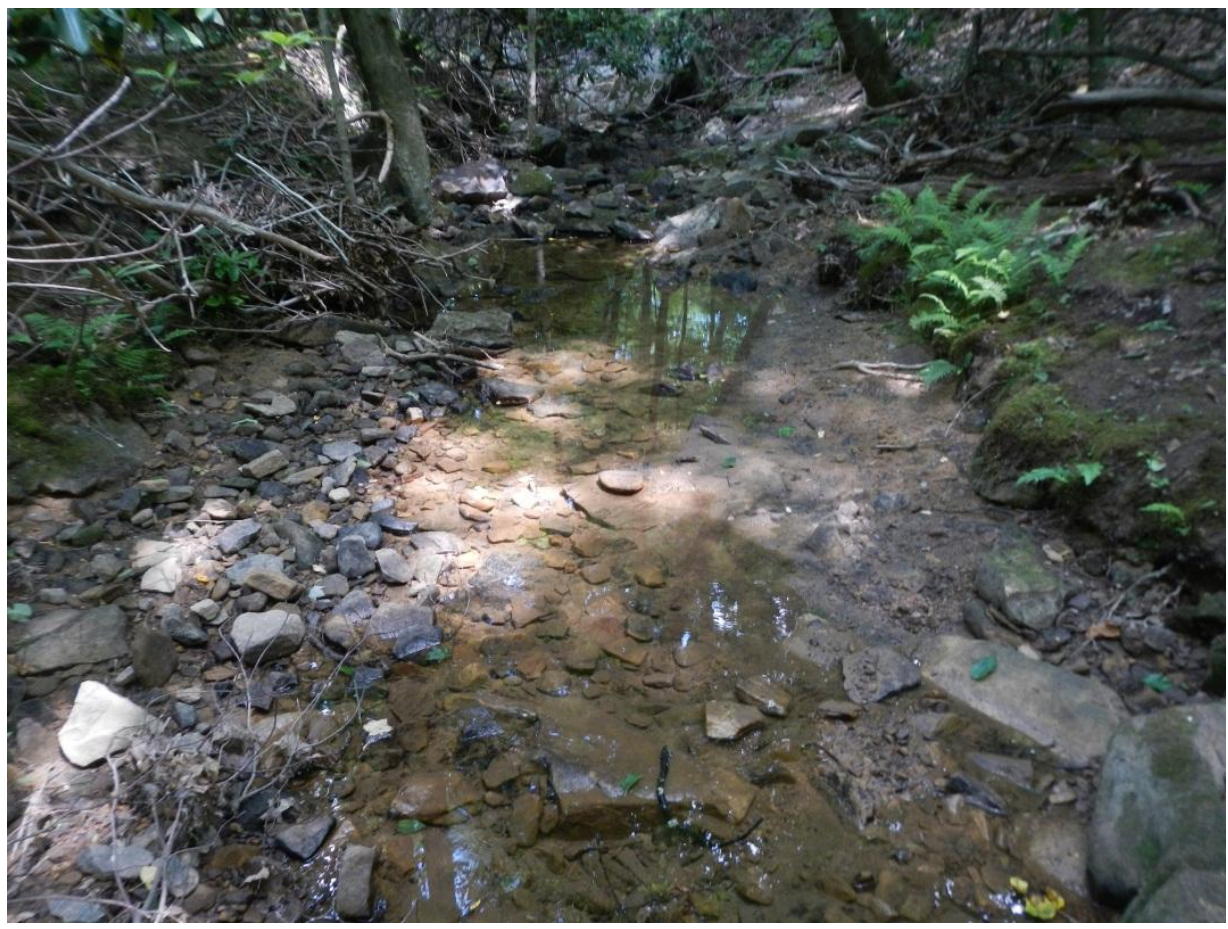

Figure 7. Laurel Run South (S Lrn) 


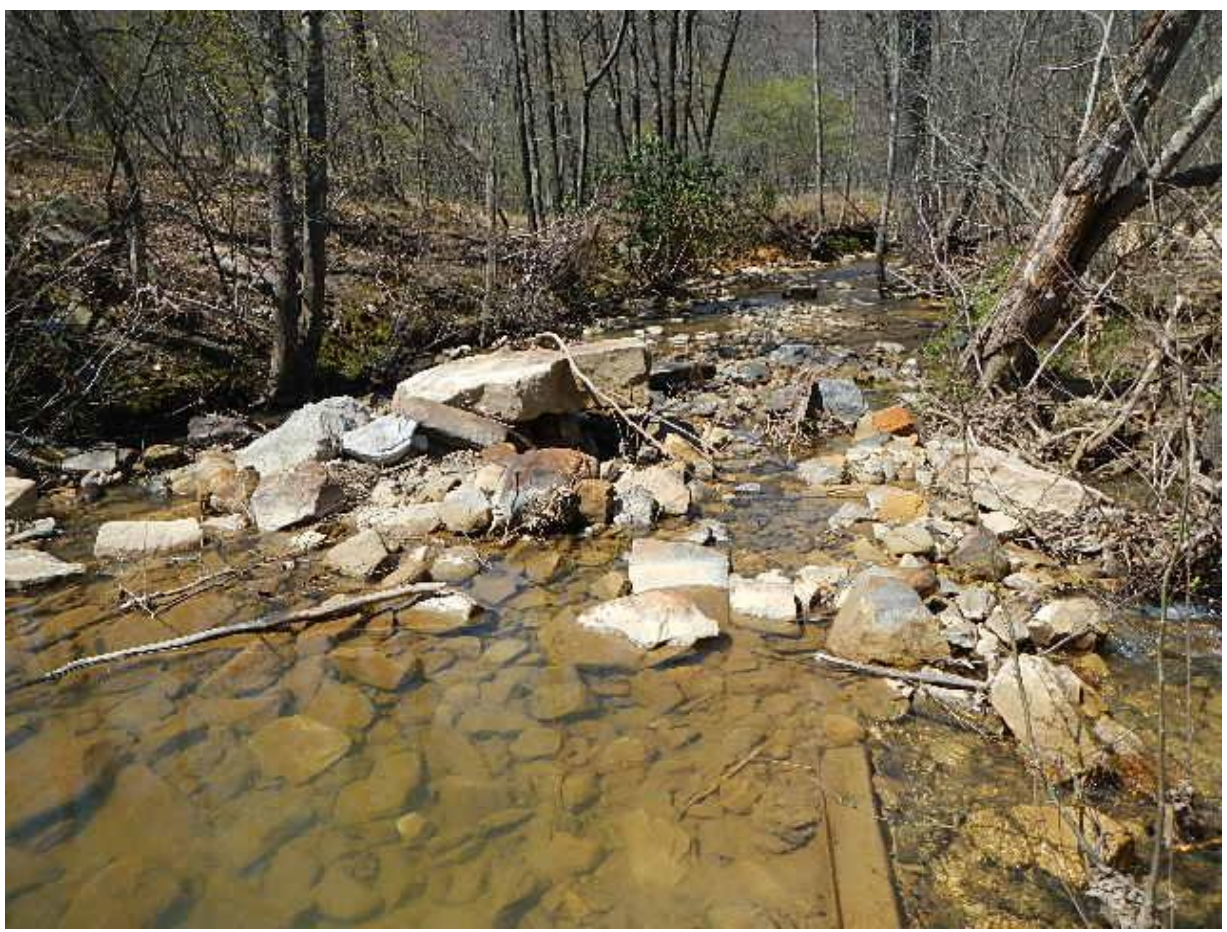

Figure 8. Whiteday Creek (WD CHRY RD)

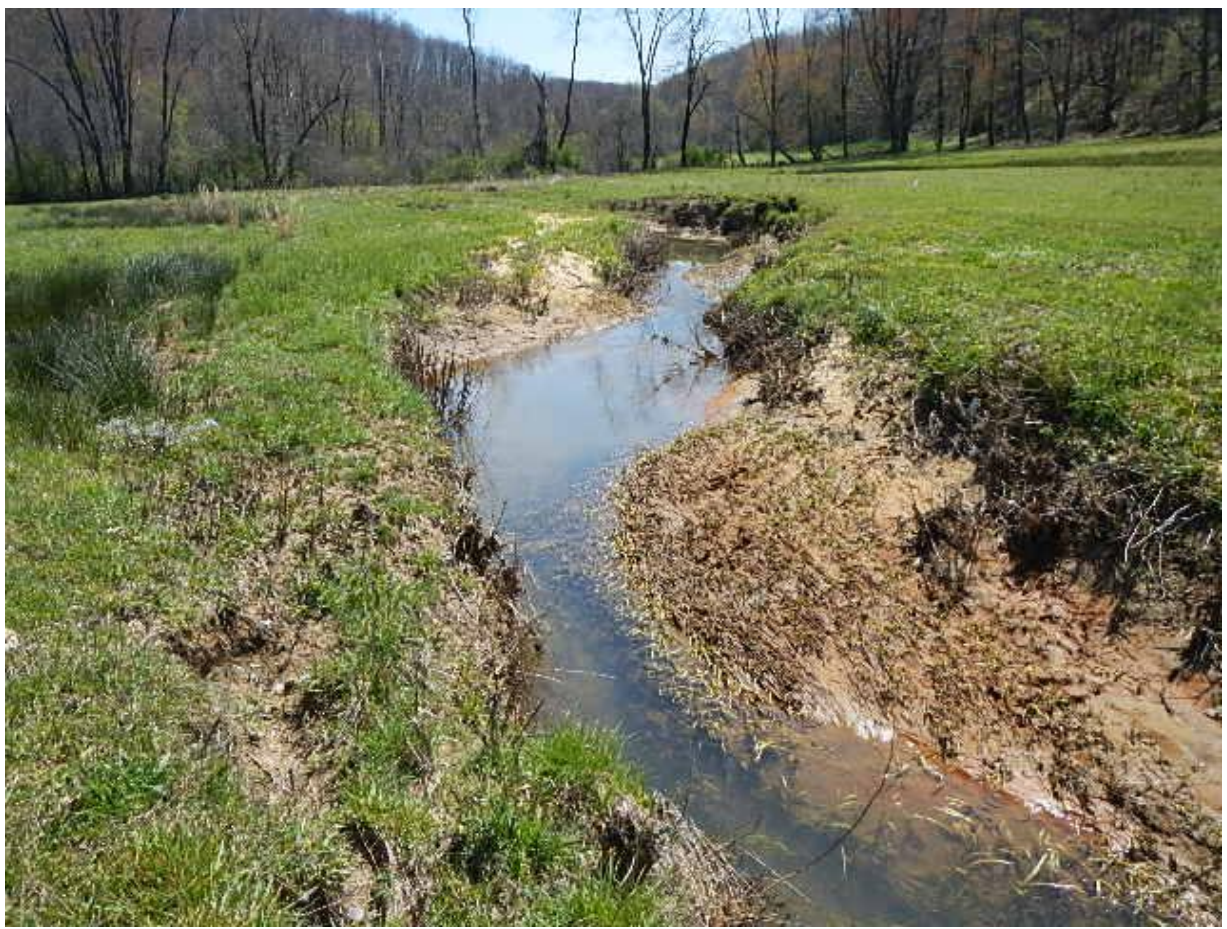

Figure 9. Whiteday Creek (WDS) 


\subsection{Water quality}

\subsubsection{Field measurements of water quality}

The YSI Pro-Plus Mulit-parameter water quality meter (Yellow Springs, Ohio) was manually used to provide instantaneous results of stream quality. The results are received from a probe which is placed in the water and data is displayed on a handheld computer. The device measures several water parameters contributing to stream quality: conductivity $(\mu \mathrm{S} / \mathrm{cm}), \mathrm{pH}$, total dissolved solids $(\mathrm{mg} / \mathrm{L})$, and temperature $\left({ }^{\circ} \mathrm{C}\right)$. To test for turbidity, a Hach $2100 \mathrm{Q}$ portable Turbidimeter (Loveland, Colorado) was used following the EPA analytical method for turbidity measurement (Method 180.1). The meter was pre-calibrated before taking the sample with the provided testing standards. Testing was performed at sites 2-9.

\subsubsection{Continuous measurements of water quality}

The Solinst LTC Levelogger Junior (Ontario, Canada) is a continuous monitor that is placed at four field sites (4,5,6, and 9; Figures 4-7) including a Barologger at site 6 (Figure 6). The LTC Levelogger Junior uses a single probe to measures level or stage $(\mathrm{m})$, temperature $\left({ }^{\circ} \mathrm{C}\right)$, and conductivity $(\mu \mathrm{S} / \mathrm{cm})$. Piezoresistive silicon with hastelloy sensor is used to measure the stream stage. The temperature is measured with a platinum resistance temperature detector (RTD). The temperature compensation range is from $10^{\circ} \mathrm{C}$ to $40^{\circ} \mathrm{C}$ at $+/-0.1^{\circ} \mathrm{C}$. Conductivity is measured with a 4-electrode platinum sensor with a range 0 to $80,000 \mu \mathrm{S} / \mathrm{cm}$. The Levelogger has a maximum of 16,000 readings with a battery life of 5 years (based on 1 reading/5 minutes). The Barologger is used to measure the barometric pressure to adjust the level measurement. The data were downloaded on a two week cycle. Figure 10 displays a deployed Levelogger at site 9.

\subsubsection{Discharge measurements}

The discharge of the stream was measured by using a Sontek Flow Tracker velocimeter (San Diego, California) and a USGS wading rod (Harrelson et al. 1994; USGS 2004). The Sontek Flow Tracker uses a multi-sensor probe that measures velocity, angle to flow, and velocity spikes. The wading rod is used to place the multi-sensor probe of the Flow Tracker at the required distance of 0.6 times the depth of water up to $1.5 \mathrm{ft}$ (USGS 2004). The site to conduct the measurements was selected in an area within a straight stretch with little to no obstruction in the streambed. The measurement is conducted in several stations across the stream for a minimum of $40 \mathrm{~s}$ reading per station. The Flow Tracker required a manual input of the 
depth and location at each station to provide dimensions that allows the Flow Tracker to calculate the measurements into a volumetric flow rate

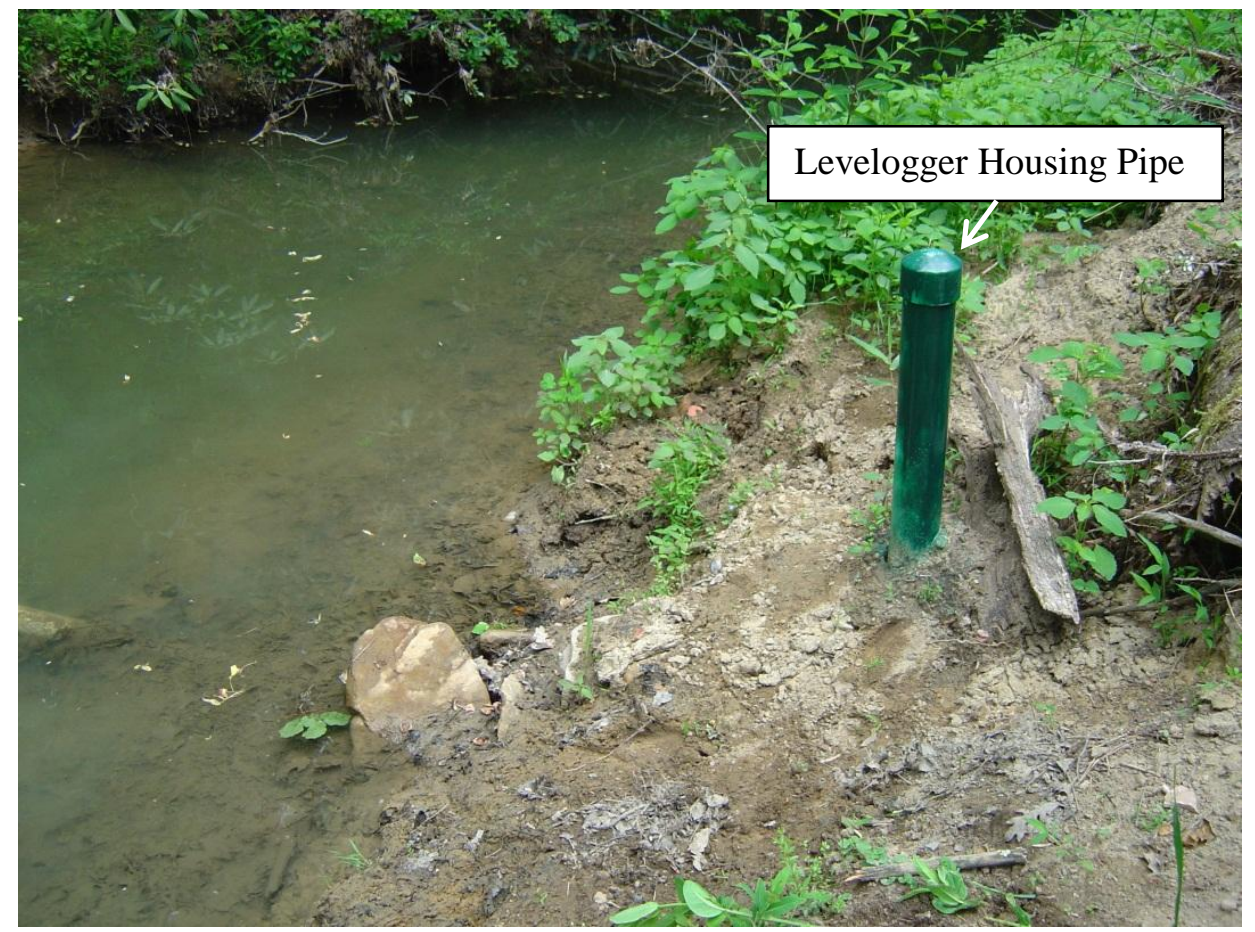

Figure 10. Deployed Levelogger Housing at Site 4 Reservoir

\subsubsection{Water grab samples}

One of the key components of the water quality sampling is our bi-weekly collection of grab samples. A grab sample is a collection of raw water from a sampling location. For the projects sampling procedure, a $500 \mathrm{~mL}$ container of raw water and a $250 \mathrm{~mL}$ container of filtered acidified water were collected from each sampling site. The $250 \mathrm{~mL}$ container was pre-acidified with nitric acid. The acid allows the raw water to remain stable until it is analyzed at the National Research Center of Coal and Energy Analytical lab at WVU. The water was filtered in the field by a hand pump and a Nalgene membrane filter assembly. The NRCCE follows EPA standards and methods to test the grab sample which is displayed in Table 2. The EPA method number and detection limit for each analyte are also identified in the table. 
Table 2. National Research Center of Coal and Energy Analytical Laboratory Standards Analyte Units Method Detection Limit EPA Method Number

\begin{tabular}{llll}
\hline $\mathrm{pH}$ & $\mathrm{mg} / \mathrm{L}$ & $1-14$ & 150.1 \\
Alkalinity & $\mathrm{mg} / \mathrm{L}$ & 1 & $\mathrm{SM} 2320 \mathrm{~B}$ \\
Acidity & $\mathrm{mg} / \mathrm{L}$ & 1 & $\mathrm{SM} 2310 \mathrm{~B}$ \\
Conductivity & $\mu \mathrm{S} / \mathrm{cm}$ & 2.2 & $\mathrm{SM} 2510 \mathrm{~B}$ \\
$\mathrm{SO} 4$ & $\mathrm{mg} / \mathrm{L}$ & 0.117 & 375.4 \\
$\mathrm{Na}$ & $\mathrm{mg} / \mathrm{L}$ & 0.1 & 200.7 \\
$\mathrm{Cl}$ & $\mathrm{mg} / \mathrm{L}$ & 0.44 & 300 \\
$\mathrm{Br}$ & $\mathrm{mg} / \mathrm{L}$ & 0.088 & 300 \\
$\mathrm{~S}$ & $\mathrm{mg} / \mathrm{L}$ & 0.047 & 200.7 \\
$\mathrm{TSS}$ & $\mathrm{mg} / \mathrm{L}$ & 2.37 & $\mathrm{SM} 2540 \mathrm{D}$ \\
$\mathrm{TDS}$ & $\mathrm{mg} / \mathrm{L}$ & 3.4 & $\mathrm{SM} 2540 \mathrm{C}$ \\
$\mathrm{Al}$ & $\mathrm{mg} / \mathrm{L}$ & 0.1 & 200.7 \\
$\mathrm{D} . \mathrm{Al}$ & $\mathrm{mg} / \mathrm{L}$ & 0.1 & 200.7 \\
$\mathrm{Ca}$ & $\mathrm{mg} / \mathrm{L}$ & 0.1 & 200.7 \\
$\mathrm{D} . \mathrm{Ca}$ & $\mathrm{mg} / \mathrm{L}$ & 0.1 & 200.7 \\
$\mathrm{Fe}$ & $\mathrm{mg} / \mathrm{L}$ & 0.1 & 200.7 \\
$\mathrm{D} . \mathrm{Fe}$ & $\mathrm{mg} / \mathrm{L}$ & 0.1 & 200.7 \\
$\mathrm{Mg}$ & $\mathrm{mg} / \mathrm{L}$ & 0.1 & 200.7 \\
$\mathrm{D} . \mathrm{Mg}$ & $\mathrm{mg} / \mathrm{L}$ & 0.1 & 200.7 \\
$\mathrm{Mn}$ & $\mathrm{mg} / \mathrm{L}$ & 0.1 & \\
$\mathrm{D} . \mathrm{Mn}$ & $\mathrm{mg} / \mathrm{L}$ & 0.1 & 0.7 \\
\hline
\end{tabular}

\subsubsection{Statistical analysis}

To determine if there was a significant difference from the upstream and downstream data, T-test statistical analysis was completed $(\alpha=0.05)$. The t-test was completed for the following data sets: temperature, $\mathrm{pH}$, conductivity, and TDS. 


\subsection{Physical properties}

\subsubsection{Channel grain size distributions}

A gravelometer was used to determine the composition of the channel substrate using a modified Wolman Pebble count (Wolman 1954; Harrelson et al. 1994). Within a riffle, 100 pebbles are collected and sized with the gravelometer. Ten random pebbles were measured in 10 passes at the experiments reaches. The data were collected and analyzed for a grain-size distribution of the channel substrate, specifically for median particle size D50, D84, and D16.

\subsubsection{Channel dimensions}

Channel cross sections were measured with traditional surveying equipment following the procedure detailed by Harrelson et al. (1994). To execute the cross-section a perpendicular alignment to the bankfull channel should be placed on both sides of the stream, typically by driving steel pins into the ground. A measuring tape is then used to connect the pins to perform the survey at each $0.5 \mathrm{~m}$. In addition to the $0.5 \mathrm{~m}$ intervals, other features, top of bank, bankfull, right edge of bed, water surface, thalweg, should be recorded to illustrate the channel more precisely. Finally, pictures were taken at the stream where the cross-sections are performed (left bank, right bank, upstream, and downstream; Appendix A Figures 20-27).

\subsubsection{Ecological properties}

A catch net was used to complete benthic macro invertebrate sampling. A $1 \mathrm{~m}^{2}$ catch net was attached to two poles and held in the stream. This procedure required two people, one to hold the net and the other to kick the stream. "To kick the stream" means to kick around the stream bed in about $1 \mathrm{~m}^{2}$, preferably in a riffle. This will bring the macro invertebrates up from the bottom of the stream bed and the current will transport them into the catch net. In addition to kicking, larger rocks must be picked from the stream and cleaned off to remove the macroinvertebrates that are clinging to be rock (WVDEP 2011). Three kicks or 100 macroinvertebrates were collected at each site.

Once the kick was completed the net was removed from the stream. The net was then placed into a bucket with a sieve and washed down to move the contents from the net into the sieve. After removing the net from the sieve examine it to see if any macro invertebrates were still present. The sieve contained the macro invertebrates and contents from the stream bed 
which need to be sorted and counted. Finally, the benthic macro invertebrates were identified, and condition index was calculated for each sample.

\subsection{Sampling schedule}

Table 3 presents the monitoring schedule.

Table 3. Sampling Schedule

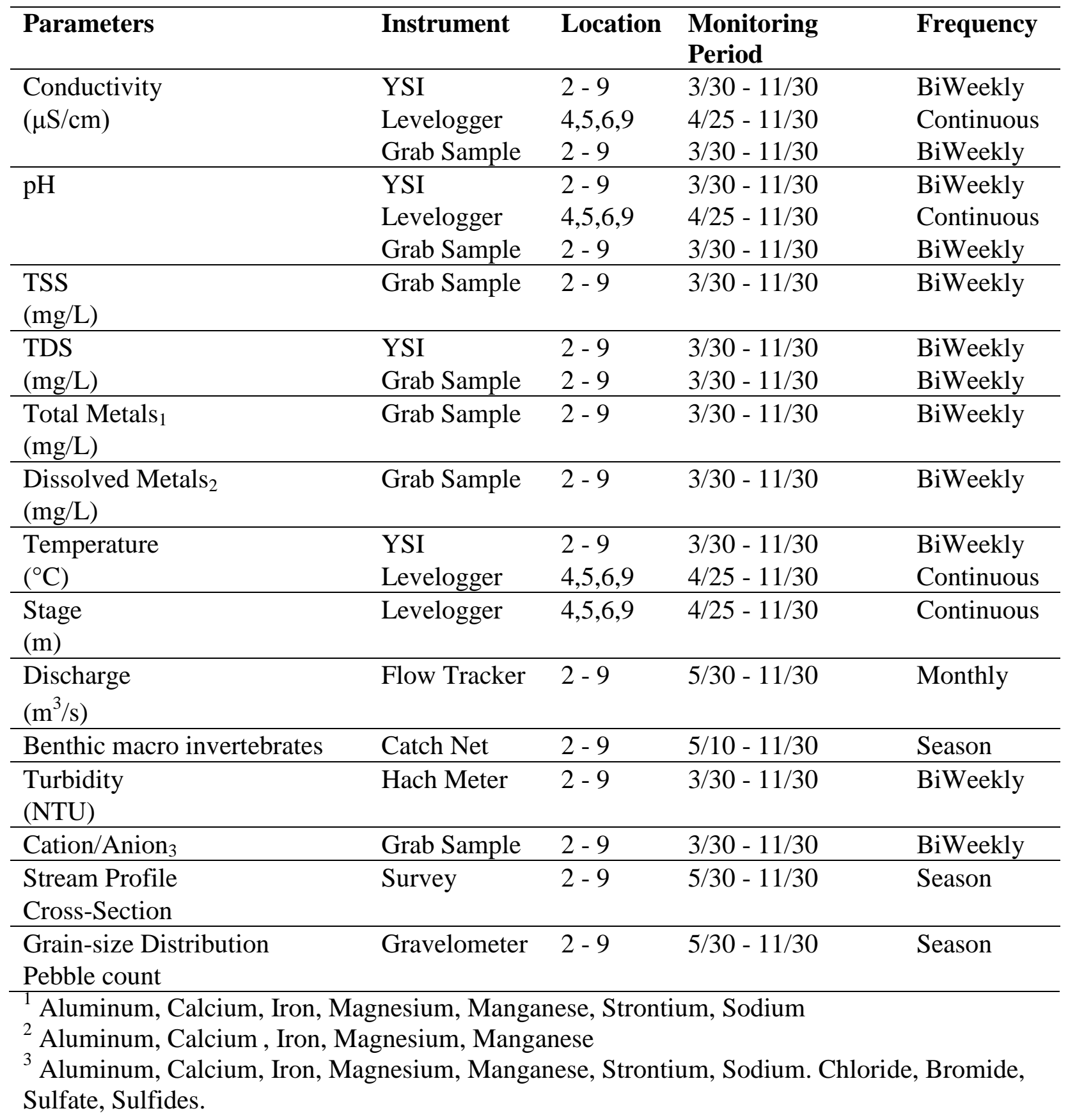




\section{Ch. 4 Results and Discussion}

To analyze the results, each analysis will be separated by permit location; Daniel Morris permit (Lck N and S Lck), Edwin Bunner permit (Resv, Lrn SE, S Lrn, and Ds Res), and Orthodox Church Society permit (WD CHRY RD and WDS). The analysis allows for the evaluation of the effects due to the different phases of development. The Daniel Morris Permit is in the pre-construction phase, Edwin Bunner is in the construction phase, and the Orthodox Church Society is an inactive site. Twelve samples were collected and analyzed for most of the water quality parameters. Some parameters contained fewer samples due to land owner permission, stream conditions, and concentrations below minimal detection limits.

\subsection{YSI monitoring data}

\subsubsection{Temperature}

According to the WVDEP manual 47CSR2 parameter 8.29, stream temperature may not exceed $30.6^{\circ} \mathrm{C}$ during the months of May through November and $22.8^{\circ} \mathrm{C}$ during the months of December through April. Figure 11 illustrates the temperatures measured at each sampling site over the duration of the project.

At the Daniel Morris (pre-construction) permit, temperatures of the upstream and downstream site did not exceed WVDEP parameters. The mean temperature at the upstream location S Lck was $17.2^{\circ} \mathrm{C}$ and ranged from $10.6^{\circ} \mathrm{C}$ to $22.7^{\circ} \mathrm{C}$. At the downstream location (Lck $\mathrm{N})$, the mean temperature was $15.0^{\circ} \mathrm{C}$ and ranged from $7.9^{\circ} \mathrm{C}$ to $20.0^{\circ} \mathrm{C}$. These temperatures resulted in no statistical difference between the upstream and downstream sampling sites for the Daniel Morris permit ( $\mathrm{p}$-value=0.4218).

The water temperature of the monitoring sites at the Edwin Bunner (active) permit were similar to the water temperatures measured near the Morris Permit. At the upstream sites, Lrn SE and $\mathrm{S}$ Lrn, mean temperatures were $15.8^{\circ} \mathrm{C}$ and $15.2^{\circ} \mathrm{C}$, with ranges of $8.9^{\circ} \mathrm{C}$ to $8.6^{\circ} \mathrm{C}$, and $22.2^{\circ} \mathrm{C}$ to $20.3^{\circ} \mathrm{C}$, respectively. The mean temperature at downstream sites, Resv and Ds Res, measured $16.0^{\circ} \mathrm{C}$ and $16.1^{\circ} \mathrm{C}$, with lows of $8.4^{\circ} \mathrm{C}$ and $9.9^{\circ} \mathrm{C}$, and highs of $21.9^{\circ} \mathrm{C}$ and $21.2^{\circ} \mathrm{C}$ respectively. The temperatures from the Bunner permit measured well under the WVDEP parameter of $30.6^{\circ} \mathrm{C}$, and resulted in no significant differences between upstream and downstream sampling sites ( $\mathrm{p}$-value $=0.820)$. 

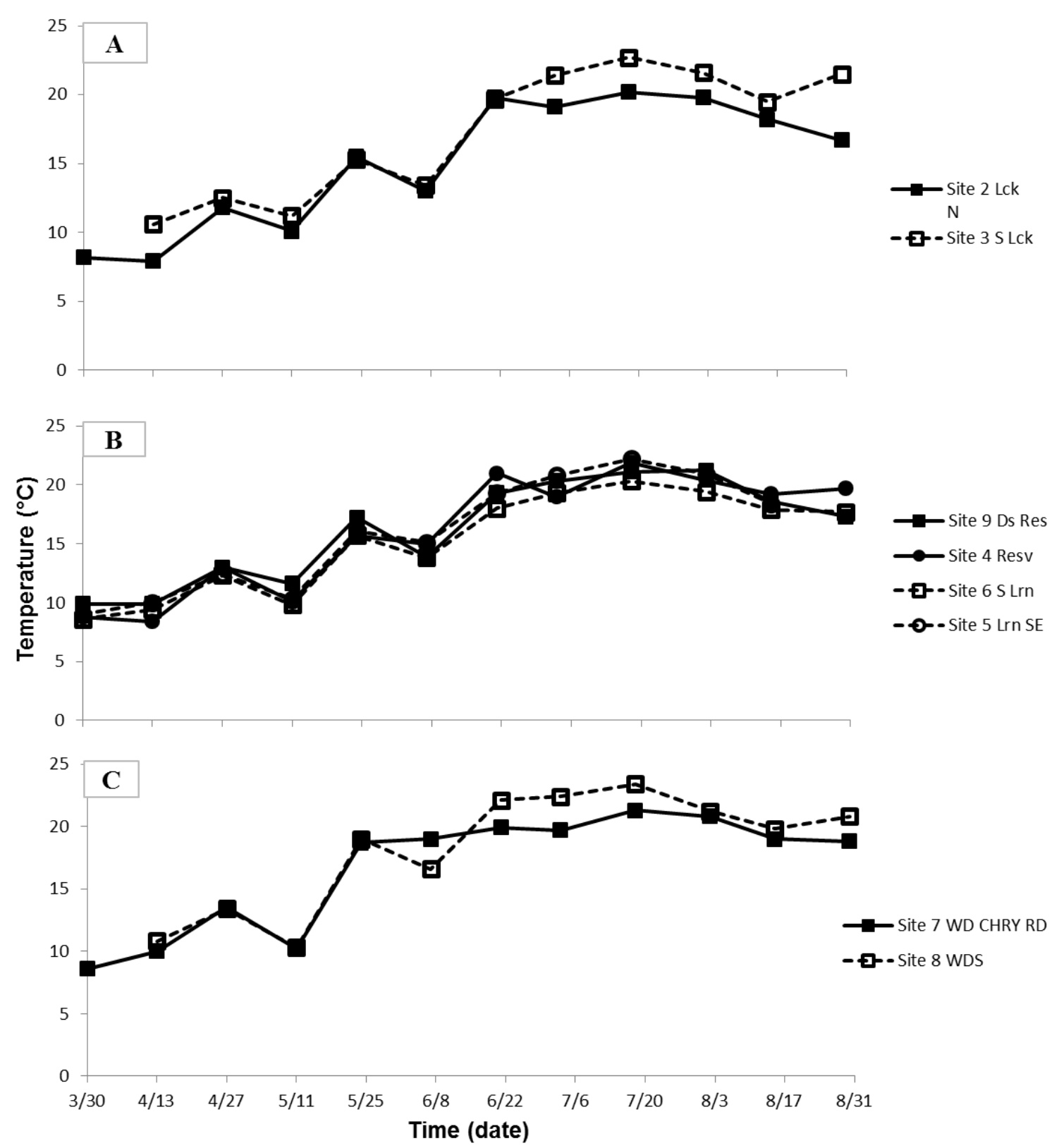

Figure 11. Distribution of temperature $\left({ }^{\circ} \mathrm{C}\right)$ for the A) Daniel Morris permit preconstruction field site, B) Edwin Bunner permit active field site, and C) Orthodox Church Society inactive field sites (open markers represent upstream sites and solid markers are downstream sites).

Temperatures measured at the Orthodox Church Society (inactive) permit were slightly higher than the other permits due to the lack of foliage cover; however, measurements did not exceed the WVDEP parameter of $30.6^{\circ} \mathrm{C}$. The stream regularly flows through open pasture fields, until slightly upstream of WD CHRY RD when canopy cover first begins. Mean 
temperature at WDS was $18.2^{\circ} \mathrm{C}$, and ranged from $10.3^{\circ} \mathrm{C}$ to $23.4^{\circ} \mathrm{C}$. The temperature at the downstream site WD CHRY RD varied little with a mean of $16.6^{\circ} \mathrm{C}$, and ranged from $8.6^{\circ} \mathrm{C}$ to $21.3^{\circ} \mathrm{C}$. Statistical analysis indicated that the two sites were statistically the same (p-value $=0.6722)$.

The stream temperatures for all three permits measured under the WVDEP manual 47CSR2 parameter 8.29 of $30.6^{\circ} \mathrm{C}$. All sampling sites, with the exception of WDS, were nested in heavy tree cover. This provided shady conditions to lower the rate of change in temperature. There was no removal of trees near any of the sampling sites during this monitoring period.

\subsection{2 pH}

For this project, $\mathrm{pH}$ measurements outside the range of $6.0-9.0$ will be considered to have negative stream impacts (WVDEP 2011). Figure 12 illustrates the $\mathrm{pH}$ measurements for each permit at the sampling sites. At the Daniel Morris (pre-construction) permit a mean $\mathrm{pH}$ at $\mathrm{S}$ Lck was 7.3 and ranged from 6.9 to 8.2. The downstream site Lck $\mathrm{N}$ mean $\mathrm{pH}$ was 7.8 , and the range was 7.5 - 8.6. Statistical analysis supports that the $\mathrm{pH}$ from $\mathrm{S}$ Lck is statistically different when compared to Lck N (p-value=0.0110). 


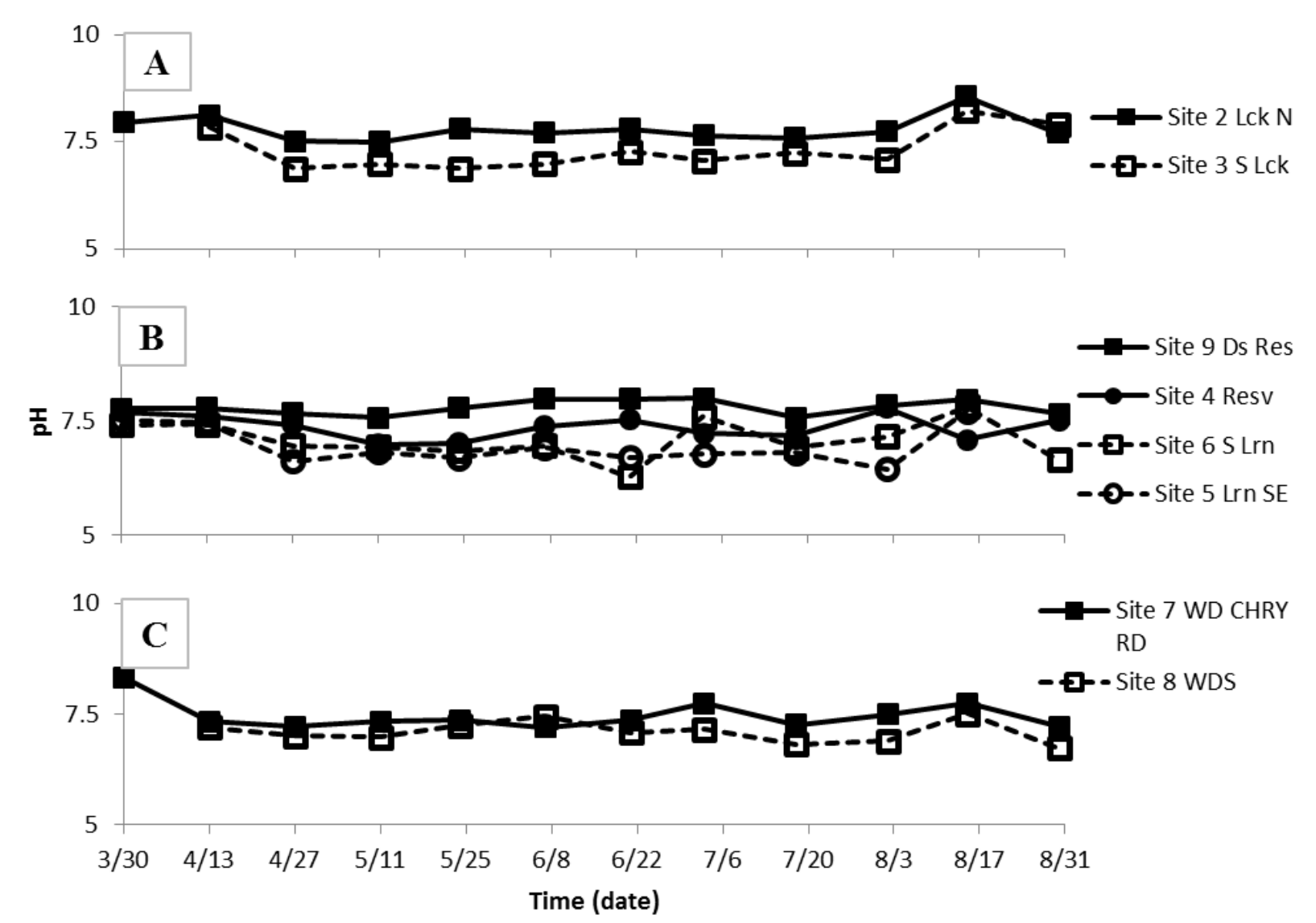

Figure 12. Distribution of pH for the A) Daniel Morris permit pre-construction field site, B) Edwin Bunner permit active field site, and C) Orthodox Church Society inactive field sites (open markers represent upstream sites and solid markers are downstream sites).

The upstream and downstream $\mathrm{pH}$ measurements at the Edwin Bunner (active) site were somewhat different. The mean $\mathrm{pH}$ at the upstream sites, Lrn SE and S Lrn, was 6.9 and 7.1, respectively. The $\mathrm{pH}$ ranges for these sites were 6.4 to 7.7 (Lrn SE) and 6.3 to 7.8 (S Lrn). The mean $\mathrm{pH}$ at the downstream sites, Resv and Ds Res, was 7.4 and 7.8, respectively. The downstream pH range was 7.0 to 7.8 (Resv) and 7.6 to 8.0 (Ds Res). Statistical analysis indicates that the $\mathrm{pH}$ is statistically the same between the S Lrn and Lrn SE (p-value=0.3627). Statistical analysis indicated that the $\mathrm{pH}$ measurements at the upstream and downstream sites are statistically different ( $\mathrm{p}$-value $=0.0154)$.

The Orthodox Church Society (inactive) permit resulted in $\mathrm{pH}$ levels similar to the Bunner permit. Measurements from upstream WDS resulted in a mean $\mathrm{pH}$ of 7.1 and ranged from 6.7 to 7.5. The mean $\mathrm{pH}$ at WD CHRY Rd was 7.5 and ranged from 7.3 to 8.3. Statistical analysis indicated that the two sites are statistically different ( $\mathrm{p}$-value $=0.0064$ ). 
This water quality parameter measured within the safe $\mathrm{pH}$ zone for all sample sites. The T-test results support statistical differences between upstream and downstream $\mathrm{pH}$ data. However, the data did not suggest that Marcellus shale activity was responsible for the differences in $\mathrm{pH}$ measurements. Runoff from the nearby limestone shouldered roadway could have influenced the $\mathrm{pH}$ (Nord and Mortensen 2010).

\subsubsection{Turbidity}

The WVDEP states that turbidity levels become harmful if the measured turbidity is more than 10 NTU above the streams background turbidity. Background turbidity is usually the historic measurement at low flows, excluding measurements influenced by runoff (DEQ 2005). However, it is important to note that in 2008 the Minnesota Pollution Control Agency (MPCA) stated that cool/warm water fishery should have a turbidity not exceeding 25 NTU. Beyond this point, the quality of water is degraded such that it becomes harmful to aquatic life. The background turbidity for this project will be a calculated mean based from field measurements. The field sites with measurements no more than 10 NTU above that average turbidity will be considered an "acceptable turbidity". Any measurement exceeding the acceptable turbidity is considered to be harmful to the streams health. Figure 13 illustrates the measured turbidity organized by permit. 

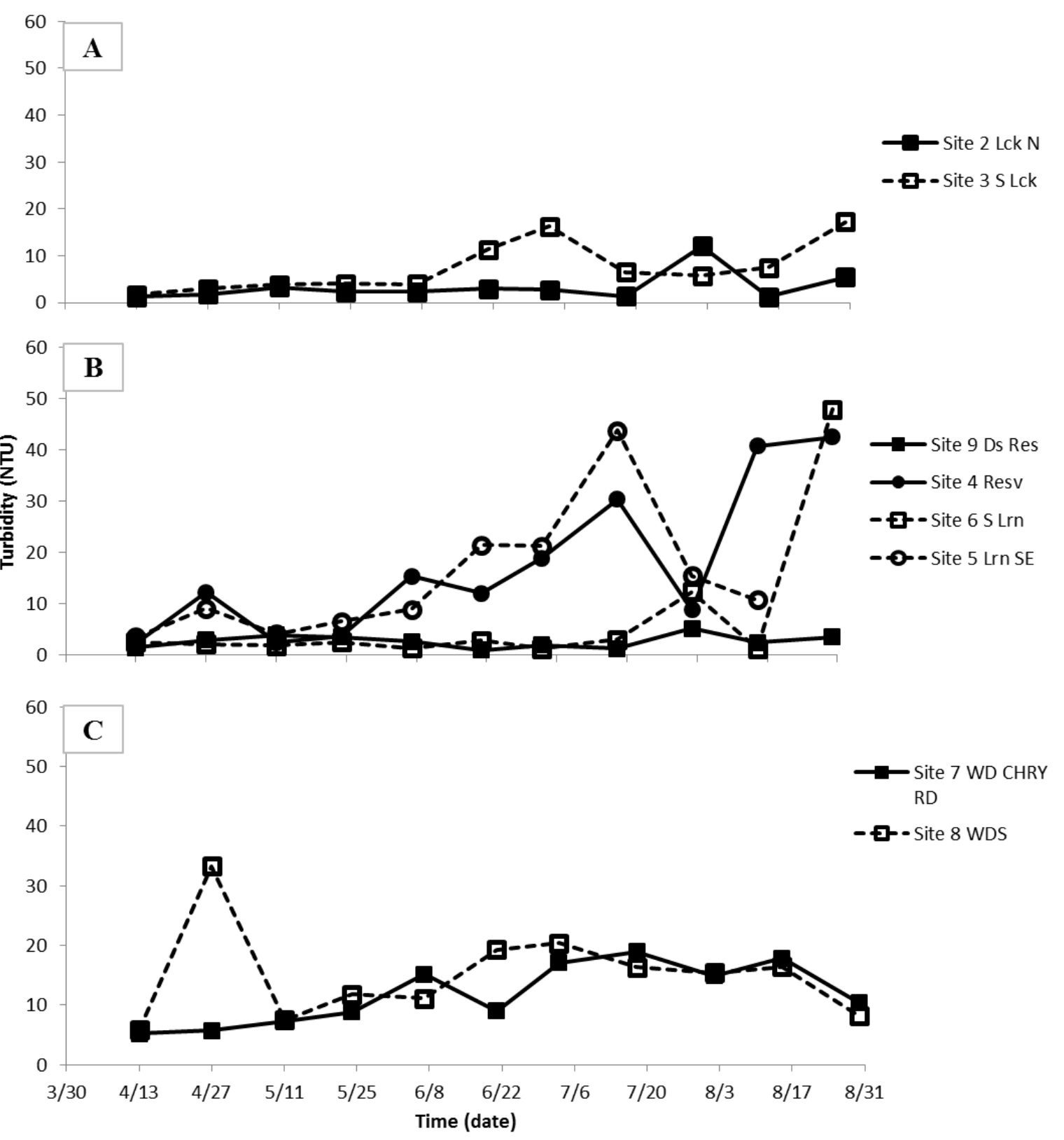

Figure 13. Distribution of turbidity (NTU) for the A) Daniel Morris permit preconstruction field site, B) Edwin Bunner permit active field site, and C) Orthodox Church Society inactive field sites (open markers represent upstream sites and solid markers are downstream sites). 
The mean turbidity of Lck N of the Daniel Morris (pre-construction) permit was 2.45 NTU and ranged from 1.19 NTU to 5.38 NTU. An outlier of 12.1 NTU occurred, but was still within its acceptable turbidity range. Upstream S Lck had a mean turbidity of 4.50 NTU, and ranged from 1.72 NTU to 7.46 NTU (Figure 13). The results contained three outliers, two of which exceeded its acceptable turbidity. These high turbidity measurements could have been a result of weather conditions. The turbidity measurement from July 3 may have resulted from a storm event three days prior. There was a noticeable increase in water level on this day of sampling (Figure 14). The high turbidity measurement from August 30 was likely attributed to suspended organic matter as a result of fallen leaves. It is important to note the last precipitation of $2.2 \mathrm{~cm}$ occurred nine days prior to this date. Statistical analysis supports that the turbidity from S Lck is statistically different when compared to Lck N (p-value $=0.0453$ ).

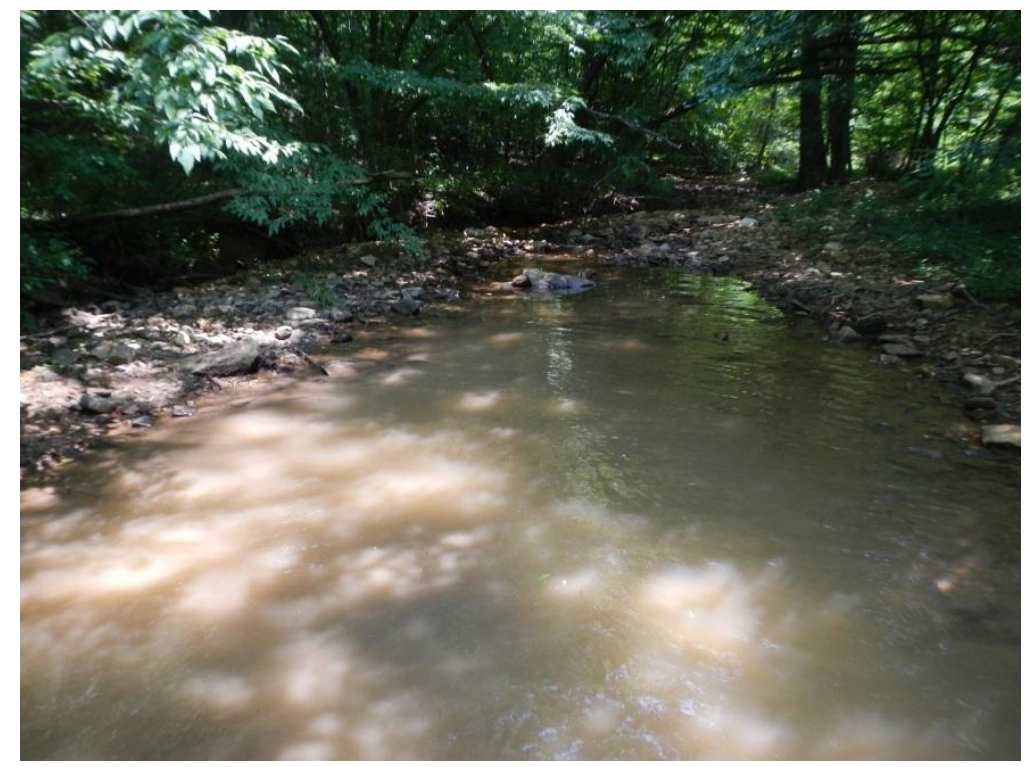

Figure 14. Site 3 South Lick Run (S Lck) on July 3, 2012.

The turbidity at the Edwin Bunner (active) permit was measured at the two upstream and two downstream sampling sites. The two upstream sites Lrn SE and S Lrn were independent streams, and turbidity measurements differed (p-value=0.0101). Turbidity measured at Lrn SE resulted in a mean upstream turbidity of 8.37 NTU, and ranged from 3.57 NTU to 15.50 NTU. Three consecutive measurements in the months of June and July exceeded its acceptable turbidity. The high turbidity measurements were 21.40 NTU, 21.20 NTU, and 43.70 NTU. The first two measurements occurred during a period with no precipitation. Water levels fell and the stream consisted of small pools, which could have raised the turbidity. The largest measured 
turbidity at Lrn SE likely occurred due to precipitation. Five days before the sample was collected, the watershed received no precipitation for twelve days. However, during that five day period before sampling, two storm events occurred. With the previous dry conditions, the rainfall could have collected the dry, loose surface soil particles and transported them directly to the stream increasing the turbidity.

Turbidity at S Lrn was lower than Lrn SE. The mean turbidity was 2.10 NTU and ranged from 1.24 NTU to 3.09. The turbidity of the stream measured beyond acceptability twice in the month of August. Stream water levels were at the lowest during this month. As the water level decreased, only standing pools remained in the stream. The pools collected falling leaves and soil particles transported by wind. Eventually, the stream developed a thin surface layer of scum. The final sample collected from this site on August 30 recorded the highest turbidity of any site during this sampling period. This high measurement may have been attributed to organic matter collecting in the standing pool where the measurement was sampled.

Like the upstream sites, statistically different turbidity measurements ( $p$-value $=0.00362$ ) were recorded at the downstream sites. The downstream site closest to permitted area Resv, resulted in a mean turbidity of 9.48 NTU. Turbidity ranged from 2.40 NTU to 18.90 NTU. There were three measurements that exceeded its acceptable turbidity. The samples were collected in July and August as the streams water level decreased, flow rate was non-existent, and more organic matter became present due to the change of season. The final two turbidity samples at Resv collected were 40.70 NTU and 42.50 NTU. Ds Res measured the lowest values of turbidity surrounding the permitted area with a mean turbidity of $2.72 \mathrm{NTU}$, and ranged from $1.02 \mathrm{NTU}$ to 5.18 NTU. There were no measurements that exceeded acceptable turbidity at this site. It is important to note that this site is located downstream of a reservoir, which is located just downstream of Resv. The reservoir could have collected the particles, causing them to settle and discharge less turbid water. The concept is supported by the differences in turbidity measurements from Resv at the reservoir, compared to that of Ds Res downstream. Turbidity at Resv measured 42.50 NTU on August 30, while turbidity recorded at Ds Res was 3.54 NTU. The reservoir acts like a clarifier at a water treatment plant. Particles that contribute to turbidity are settling which allows clean water to exit the reservoir naturally, providing better water quality for aquatic life. 
The mean turbidity for the inactive Orthodox Church Society (inactive) permit was greater upstream than downstream, but the differences were not statistically significant (pvalue $=0.2662$ ). The mean turbidity for the upstream site (WDS) was $15.00 \mathrm{NTU}$, and had a range of 5.78 to 33.3 NTU. The downstream WD CHRY RD mean turbidity was 11.80 NTU, with a range of 5.16 to $18.90 \mathrm{NTU}$. The upstream WDS had a single turbidity measurement that exceeded the 10 NTU greater than background turbidity. However, the turbidity measurements ranged below $25 \mathrm{NTU}$ for the remainder of the monitoring period.

\subsubsection{Conductivity}

To assist in determining if the conductivity measurements of these sites were harmful to the streams health, the EPA benchmark of $300 \mu \mathrm{S} / \mathrm{cm}$ conductance will be used. Conductivity average will be calculated with measurements that are below the EPA benchmark. Measurements that exceed the benchmark will be considered outliers. Figure 15 illustrates the conductivity measurements at each of the sites and permit location. 

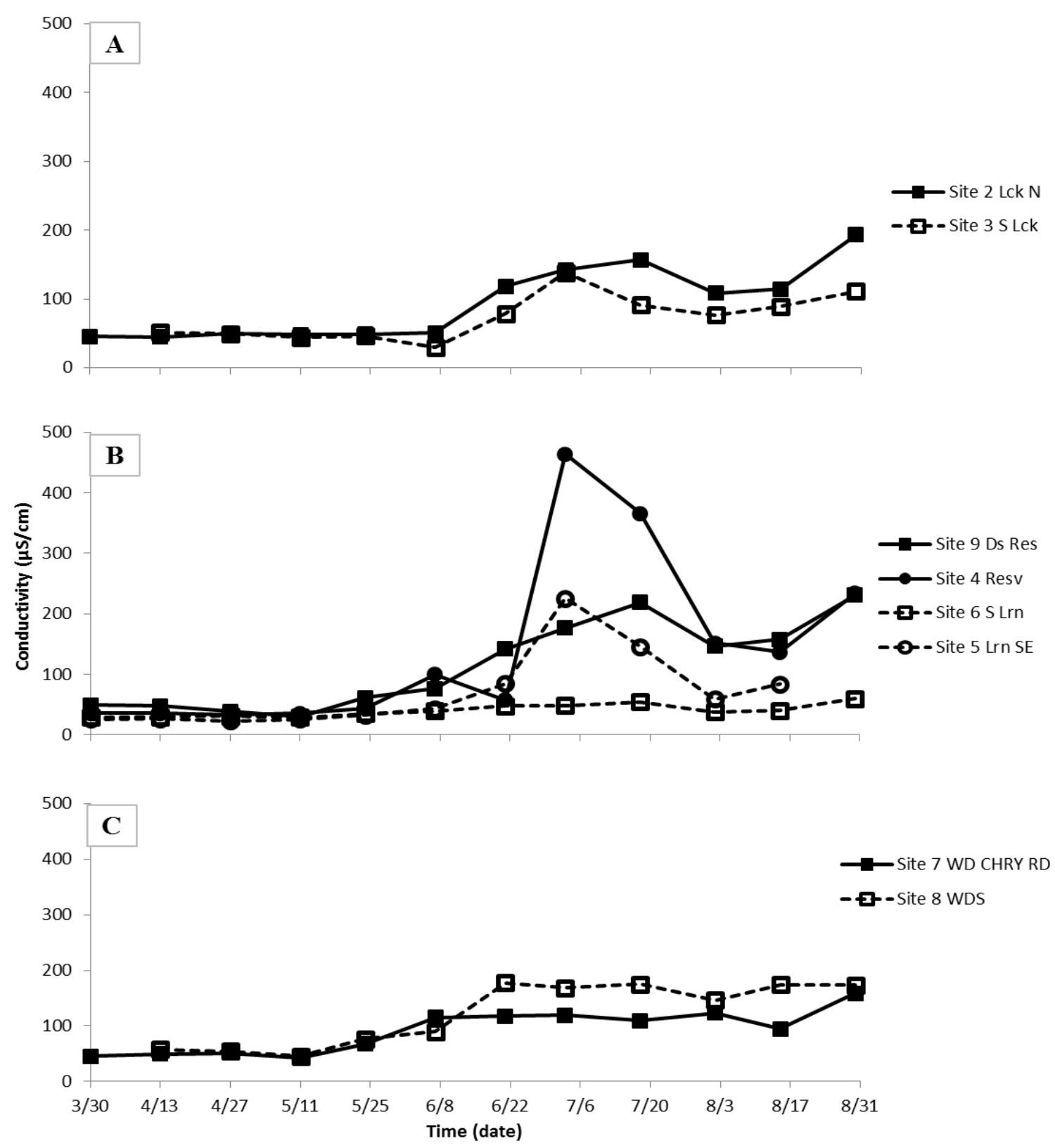

Figure 15. Distribution of conductivity $(\mu \mathrm{S} / \mathrm{cm})$ for the A) Daniel Morris permit preconstruction field site, B) Edwin Bunner permit active field site, and C) Orthodox Church Society inactive field sites (open markers represent upstream sites and solid markers are downstream sites).

Conductivity at the Daniel Morris (pre-construction) permit displayed the lowest mean conductivity. A mean conductivity at S Lck was $73.4 \mu \mathrm{S} / \mathrm{cm}$, and ranged from $29.7 \mu \mathrm{S} / \mathrm{cm}$ to 138.6 $\mu \mathrm{S} / \mathrm{cm}$. Mean conductivity at Lck $\mathrm{N}$ was $93.5 \mu \mathrm{S} / \mathrm{cm}$, and a range of $45.2 \mu \mathrm{S} / \mathrm{cm}-193.5$ $\mu \mathrm{S} / \mathrm{cm}$. The results display a greater conductivity downstream of the permit location when compared to the upstream measurements, but the result was not statistically significant ( $p$-value $=$ 
0.2069). However, it is important to note that the conductivity measurements were considerably lower than the EPA benchmark.

The conductivity measured at the Edwin Bunner (active) permit were greater downstream than upstream. The mean conductivity at Lrn SE and S Lrn were $70.5 \mu \mathrm{S} / \mathrm{cm}$ and $40.1 \mu \mathrm{S} / \mathrm{cm}$, respectively. Conductivity at Lrn SE ranged from $22.9 \mu \mathrm{S} / \mathrm{cm}$ to $225.5 \mu \mathrm{S} / \mathrm{cm}$, while conductivity at S Lrn ranged from $28.8 \mu \mathrm{S} / \mathrm{cm}$ to $59.9 \mu \mathrm{S} / \mathrm{cm}$. Elevated conductivity measurements were not recorded until air temperatures increased and water levels decreased. The downstream sites of the Bunner permit resulted in higher conductivity measurements than the upstream measurements. Mean conductivity at Resv was $86.3 \mu \mathrm{S} / \mathrm{cm}$, and ranged from 32.5 $\mu \mathrm{S} / \mathrm{cm}$ to $234.2 \mu \mathrm{S} / \mathrm{cm}$ with two measurements exceeding the EPA benchmark. Elevated conductivity measurements at this site may have been a result of the dry weather and low flow stream conditions. Another contributor may be the redesigned curve and roadway that was reconstructed for manageable truck traffic (Figure 16).

A mean conductivity at Ds Res was $114.5 \mu \mathrm{S} / \mathrm{cm}$, and ranged from $29.3 \mu \mathrm{S} / \mathrm{cm}$ to 230.6 $\mu \mathrm{S} / \mathrm{cm}$. The mean conductivity was slightly higher for this site due to several measurements that ranged from $140.0 \mu \mathrm{S} / \mathrm{cm}$ to $230.6 \mu \mathrm{S} / \mathrm{cm}$. 




Figure 16. Redesigned curve at the reservoir.

Results from the Edwin Bunner (active) permit illustrates an increase in conductivity from upstream to downstream sites (p-value=0.1954). However, only two measurements exceeded the EPA benchmark of $300 \mu \mathrm{S} / \mathrm{cm}$. The results do not provide enough evidence to determine whether or not that the permitted site had any impact to the streams health, but suggest that it should be further considered.

Conductivity measured at the Orthodox Church Society (inactive) permit resulted in a mean and range of $121.7 \mu \mathrm{S} / \mathrm{cm}$ and $45.6 \mu \mathrm{S} / \mathrm{cm}-177.5 \mu \mathrm{S} / \mathrm{cm}$, respectively, for the WDS site. At the downstream site WD Chry Rd, the mean conductivity was $91.2 \mu \mathrm{S} / \mathrm{cm}$ and ranged from $41.8 \mu \mathrm{S} / \mathrm{cm}$ to $159.0 \mu \mathrm{S} / \mathrm{cm}$. The results from this permitted area indicate no harmful measurements of conductivity. All samples measured well under the EPA benchmark of 300 $\mu \mathrm{S} / \mathrm{cm}$. Statistical analysis indicated that the two sites are statically similar ( $\mathrm{p}$-value $=0.2118$ ), as expected due to no disturbances affecting the sites differently. This result will provide a useful database for future monitoring purposes. 


\subsection{Benthic analysis}

The West Virginia Stream Condition Index (WVSCI) was used in this study to analyze the macroinvertebrate collection samples and to determine the overall integrity of the streams. WVSCI was established by Tetra Tech Inc. (2000), which used data of riffle habitat in wadeable streams developed by the WVDEP and EPA. The WVSCI is calculated by the various species and number of macroinvertebrates collected in a reach of a stream. All macroinvertebrate collection data are displayed in Appendix B. The WVSCI uses a point scale (0.0-100.0) to determine overall stream quality. A threshold of 68.0 was implemented to determine if a stream is biologically impaired or unimpaired. A stream is biologically impaired if the WCSCI score is under the threshold, and biologically unimpaired if score is above the threshold. To account for variability in sampling, a precision estimate of 7.4 WVSCI points was subtracted from the original threshold of 68.0 to create a "gray zone" of 60.6 to 68.0 points of the WVSCI. Variability in sampling exists due to errors by the collector, habitat sampled, and the sampling procedure performed by the collector.

Table 4. Macroinvertebrate scores for field sites.

\begin{tabular}{lccc}
\hline Field Sites & Stream Score & WV SCI Score & Integrity Rating \\
\hline Site 2 Lck N & 20 & 66.7 & Suboptimal \\
Site 3 S Lck* & 16 & 53.3 & Marginal \\
Site 4 Resv & 14 & 46.7 & Marginal \\
Site 5 Lrn SE* & 20 & 66.7 & Suboptimal \\
Site 6 S Lrn* & 24 & 80 & Suboptimal \\
Site 7 WD CHRY RD & 14 & 46.7 & Marginal \\
Site 8 WDS* & NA & NA & NA \\
Site 9 Ds Res & 18 & 60 & Marginal \\
\hline * Indicates upstream monitoring sites. & &
\end{tabular}

The upstream and downstream macroinvertebrate WVSCI scores (Table 4) for the Daniel Morris (pre-construction) permit resulted in a score of 66.7 for the downstream location Lck N, which was greater than the upstream S Lck score of 53.3. The WVSCI score of the upstream site indicated a marginal integrity rating and a biologically impaired stream condition. However, the downstream site resulted in a suboptimal integrity rating and scored in the "gray zone" of the WVSCI classifying the stream as biologically unimpaired. These results illustrated that the quality of the stream based on macroinvertebrate collection improved from the upstream site to the downstream site. This also confirms that the pre-construction at the Daniel Morris permit has not affected the macroinvertebrate communities within the stream. 
The data collected at the Edwin Bunner (active) permit differed from that of the Daniel Morris permit. This permit site was in the post construction phase of development when the macroinvertebrate collection was performed. The WVSCI scores for the upstream sites were 66.7 (Lrn SE) and 80.0 (S Lrn). The scores indicate that the sites were suboptimal and are considered to be biologically unimpaired. WVSCI scores for the downstream sites were 46.7 (Resv) and 60.0 (Ds Res). These scores indicate that the downstream sites had marginal stream conditions and are categorized as a biologically impaired stream.

When the results of the upstream and downstream sites are compared, differences in WVSCI scores were detected. The lowest score was the sample collected at the reservoir head (Resv). This sample site is directly located down slope of the permitted drill site. Drainage from a redesigned curve, constructed by the drilling company for a larger turning radius (Figure 16), feeds directly into the stream at the sampling site. However, it is important to note that the flow rate in this section of the stream is near non-existent. Ds Res is located below the reservoir and further downstream of the permit location. The score at this sampling site was not above the WVSCI threshold, but was greater than at the reservoir head: 60.0 to 46.7. These downstream results illustrate two conclusions: 1) the stream is naturally recovering to its upstream conditions since there is an improvement in the WVSCI scores the further downstream the sample was collected, and 2) there is something contributing to the loss of macroinvertebrate communities at the reservoir head (Resv).

The macroinvertebrate analysis of the Orthodox Church Society permit was only collected at the downstream site WD CHRY RD. Samples at WDS were not collected due to unsafe water conditions. The Orthodox Church Society permit is in the inactive phase of development, which means that no physical environmental changes have occurred in the permitted area. The results from WD CHRY RD were a WVSCI score of 46.7, which translates to marginal stream conditions and a biologically impaired stream for macroinvertebrates. These results are valuable for baseline data in future monitoring due to the inactivity of the permit.

\subsection{Lab analysis}

The National Research Center of Coal and Energy (NRCCE) Analytical Laboratory analyzed the water samples for the water quality parameters displayed in Table2. Some parameter limits are from the WVDEP title 47CSR2, while others are from the EPA Safe 
Drinking Water Act (SDWA) primary and secondary standards. Certain parameters were the focus of analysis due to their concentrations in flowback water from Marcellus shale fracturing. Studies completed by Penn State University (2011) and T. Hayes (2009) analyzed and characterized the physical composition of flowback water. From these studies, the constituents with the highest concentrations were: TDS $(67,300 \mathrm{mg} / \mathrm{L})$, sodium $(18,000 \mathrm{mg} / \mathrm{L})$, hardness (calcium and magnesium; 17,700 mg/L), chloride (41,850 mg/L), sulfate (2.4-106 mg/L), and bromide $(445 \mathrm{mg} / \mathrm{L})$. The results were analyzed for elevated concentrations of the previously listed constituents.

The results of the upstream and downstream site for the Daniel Morris (pre-construction) permit differed slightly (Table 5). The mean TDS values were $77.5 \mathrm{mg} / \mathrm{L}$ and $65.8 \mathrm{mg} / \mathrm{L}$, for the upstream and downstream site, respectively. No measurements exceeded the EPA limit of 500 $\mathrm{mg} / \mathrm{L}$. The mean sodium concentrations were $1.32 \mathrm{mg} / \mathrm{L}$ and $2.56 \mathrm{mg} / \mathrm{L}$, for the upstream and downstream site, respectively. No measurements exceeded the EPA limit of $100 \mathrm{mg} / \mathrm{L}$. The hardness for the upstream and downstream site had mean calcium concentrations of $15.1 \mathrm{mg} / \mathrm{L}$ and $9.91 \mathrm{mg} / \mathrm{L}$, with mean magnesium concentrations of $2.71 \mathrm{mg} / \mathrm{L}$ and $2.11 \mathrm{mg} / \mathrm{L}$. There is no maximum EPA limit for the constituent calcium, whose largest measured value was $35.0 \mathrm{mg} / \mathrm{L}$. Also, there were zero magnesium concentration measurements that exceeded the EPA limit of $125 \mathrm{mg} / \mathrm{L}$. The mean chloride concentration for the collected samples were $1.50 \mathrm{mg} / \mathrm{L}$ and 3.76 $\mathrm{mg} / \mathrm{L}$ with none of the concentration exceeding the EPA limit of $250 \mathrm{mg} / \mathrm{L}$. 
Table 5. NRCCE Lab analysis for the sampling sites located up and downstream of the Daniel Morris (pre-construction) permit.

\begin{tabular}{|c|c|c|c|c|c|c|c|c|c|c|}
\hline $\begin{array}{c}\text { Daniel Morris Pre-Construction } \\
\text { Site } 3 \text { South Lick Run (S Lck) }\end{array}$ & $\begin{array}{c}\text { EC (lab) } \\
(\mu \mathrm{s} / \mathrm{cm})\end{array}$ & Alk & Lab pH & $\begin{array}{c}\mathrm{Br} \\
(\mathrm{mg} / \mathrm{L}) \\
\end{array}$ & $\begin{array}{c}\mathrm{Al} \\
(\mathrm{mg} / \mathrm{L})\end{array}$ & $\begin{array}{l}\text { D. Al } \\
(\mathrm{mg} / \mathrm{L})\end{array}$ & $\begin{array}{c}\mathrm{Fe} \\
(\mathrm{mg} / \mathrm{L})\end{array}$ & $\begin{array}{r}\text { D. Fe } \\
(\mathrm{mg} / \mathrm{L})\end{array}$ & $\begin{array}{r}\mathrm{Mn} \\
(\mathrm{mg} / \mathrm{L}) \\
\end{array}$ & $\begin{array}{l}\text { D. Mn } \\
(\mathrm{mg} / \mathrm{L})\end{array}$ \\
\hline Detectable Limit & 2.2 & 1 & & 0.088 & 0.1 & 0.1 & 0.1 & 0.1 & 0.1 & 0.1 \\
\hline Number of Detectable Samples & 12 & 12 & 12 & 2 & 1 & $O$ & $O$ & $O$ & $O$ & $O$ \\
\hline Mean & 113.78 & 42.73 & 6.51 & 0.16 & 0.11 & - & - & - & - & - \\
\hline STD & 51.15 & 27.71 & 0.78 & 0.04 & - & - & - & - & - & - \\
\hline Min & 66.70 & 13.86 & 5.66 & 0.13 & 0.11 & - & - & - & - & - \\
\hline $\operatorname{Max}$ & 234.00 & 105.20 & 7.88 & 0.19 & 0.11 & - & - & - & - & - \\
\hline & $\begin{array}{c}\mathrm{S} \\
(\mathrm{mg} / \mathrm{L})\end{array}$ & $\begin{array}{c}\mathrm{Cl} \\
(\mathrm{mg} / \mathrm{L})\end{array}$ & $\begin{array}{c}\mathrm{Ca} \\
(\mathrm{mg} / \mathrm{L})\end{array}$ & $\begin{array}{l}\text { D. Ca } \\
(\mathrm{mg} / \mathrm{L})\end{array}$ & $\begin{array}{c}\mathrm{Na} \\
(\mathrm{mg} / \mathrm{L})\end{array}$ & $\begin{array}{c}\mathrm{Mg} \\
(\mathrm{mg} / \mathrm{L})\end{array}$ & $\begin{array}{l}\text { D. } \mathrm{Mg} \\
(\mathrm{mg} / \mathrm{L})\end{array}$ & $\begin{array}{l}\mathrm{SO} 4 \\
(\mathrm{mg} / \mathrm{L})\end{array}$ & $\begin{array}{c}\text { TSS } \\
(\mathrm{mg} / \mathrm{L})\end{array}$ & $\begin{array}{r}\mathrm{TDS}_{\mathrm{G}} \\
(\mathrm{mg} / \mathrm{L}) \\
\end{array}$ \\
\hline Detectable Limit & 0.047 & 0.44 & 0.1 & 0.1 & 0.1 & 0.1 & 0.1 & 0.12 & 2.37 & 3.4 \\
\hline Number of Detectable Samples & 12 & 10 & 12 & 11 & 11 & 12 & 11 & 12 & 8 & 12 \\
\hline Mean & 5.00 & 1.50 & 15.14 & 13.77 & 1.32 & 2.71 & 2.27 & 14.37 & 8.75 & 77.50 \\
\hline STD & 4.19 & 0.26 & 8.35 & 9.34 & 0.22 & 0.90 & 1.22 & 1.72 & 7.40 & 32.48 \\
\hline Min & 0.47 & 0.89 & 5.80 & 4.40 & 0.99 & 1.44 & 0.51 & 11.70 & 4.00 & 46.00 \\
\hline $\operatorname{Max}$ & 16.80 & 1.78 & 35.05 & 34.86 & 1.67 & 4.74 & 4.74 & 17.60 & 24.00 & 158.00 \\
\hline Site 2 Lick Run North (Lck N) & $\begin{array}{c}\text { EC (lab) } \\
(\mu \mathrm{s} / \mathrm{cm})\end{array}$ & Alk & Lab pH & $\begin{array}{c}\mathrm{Br} \\
(\mathrm{mg} / \mathrm{L}) \\
\end{array}$ & $\begin{array}{c}\mathrm{Al} \\
(\mathrm{mg} / \mathrm{L}) \\
\end{array}$ & $\begin{array}{l}\text { D. Al } \\
(\mathrm{mg} / \mathrm{L})\end{array}$ & $\begin{array}{c}\mathrm{Fe} \\
(\mathrm{mg} / \mathrm{L})\end{array}$ & $\begin{array}{c}\text { D. Fe } \\
(\mathrm{mg} / \mathrm{L})\end{array}$ & $\begin{array}{r}\mathrm{Mn} \\
(\mathrm{mg} / \mathrm{L}) \\
\end{array}$ & $\begin{array}{l}\text { D. Mn } \\
(\mathrm{mg} / \mathrm{L})\end{array}$ \\
\hline Detectable Limit & 2.2 & 1 & & 0.088 & 0.1 & 0.1 & 0.1 & 0.1 & 0.1 & 0.1 \\
\hline Number of Detectable Samples & 11 & 11 & 11 & 3 & 2 & $O$ & 7 & 5 & 3 & 5 \\
\hline Mean & 87.02 & 27.55 & 6.61 & 1.04 & 0.16 & - & 0.42 & 0.27 & 0.16 & 0.16 \\
\hline STD & 25.33 & 9.16 & 0.67 & 1.56 & 0.04 & - & 0.22 & 0.10 & 0.06 & 0.06 \\
\hline Min & 68.10 & 17.50 & 5.75 & 0.13 & 0.13 & - & 0.13 & 0.12 & 0.11 & 0.11 \\
\hline $\operatorname{Max}$ & 146.40 & 45.60 & 7.86 & 2.84 & 0.18 & - & 0.67 & 0.41 & 0.23 & 0.24 \\
\hline & $\begin{array}{c}\mathrm{S} \\
(\mathrm{mg} / \mathrm{L})\end{array}$ & $\begin{array}{c}\mathrm{Cl} \\
(\mathrm{mg} / \mathrm{L}) \\
\end{array}$ & $\begin{array}{c}\mathrm{Ca} \\
(\mathrm{mg} / \mathrm{L})\end{array}$ & $\begin{array}{l}\text { D. Ca } \\
(\mathrm{mg} / \mathrm{L})\end{array}$ & $\begin{array}{c}\mathrm{Na} \\
(\mathrm{mg} / \mathrm{L})\end{array}$ & $\begin{array}{c}\mathrm{Mg} \\
(\mathrm{mg} / \mathrm{L}) \\
\end{array}$ & $\begin{array}{l}\text { D. } \mathrm{Mg} \\
(\mathrm{mg} / \mathrm{L})\end{array}$ & $\begin{array}{c}\mathrm{SO} 4 \\
(\mathrm{mg} / \mathrm{L}) \\
\end{array}$ & $\begin{array}{c}\text { TSS } \\
(\mathrm{mg} / \mathrm{L})\end{array}$ & $\begin{array}{r}\mathrm{TDS}_{\mathrm{G}} \\
(\mathrm{mg} / \mathrm{L}) \\
\end{array}$ \\
\hline Detectable Limit & 0.047 & 0.44 & 0.1 & 0.1 & 0.1 & 0.1 & 0.1 & 0.12 & 2.37 & 3.4 \\
\hline Number of Detectable Samples & 11 & 11 & 11 & 10 & 11 & 11 & 10 & 11 & 9 & 11 \\
\hline Mean & 3.25 & 3.76 & 9.91 & 8.66 & 2.56 & 2.11 & 1.69 & 14.03 & 14.44 & 65.82 \\
\hline STD & 1.36 & 2.77 & 2.31 & 2.69 & 1.83 & 0.49 & 0.53 & 1.62 & 15.32 & 17.12 \\
\hline Min & 0.26 & 1.78 & 7.12 & 4.78 & 0.72 & 1.32 & 0.50 & 11.90 & 4.00 & 42.00 \\
\hline $\operatorname{Max}$ & 5.29 & 9.62 & 13.67 & 12.97 & 6.74 & 2.93 & 2.12 & 17.70 & 48.00 & 100.00 \\
\hline
\end{tabular}

The mean sulfate concentration of this permitted site was $14.37 \mathrm{mg} / \mathrm{L}$ and $14.03 \mathrm{mg} / \mathrm{L}$. None of the measurements exceeded the SDWA limit of $250 \mathrm{mg} / \mathrm{L}$. There were only five total detectable samples for the constituent bromide, whose mean values were $0.16 \mathrm{mg} / \mathrm{L}$ and 1.04 $\mathrm{mg} / \mathrm{L}$. There is not an EPA limit for this constituent. The laboratory measurement for the mean conductivity at the upstream site was $113.78 \mu \mathrm{S} / \mathrm{cm}$ and the mean conductivity at the downstream site was $87.02 \mu \mathrm{S} / \mathrm{cm}$. Both measurements were well below the parameter limit of $500 \mu \mathrm{S} / \mathrm{cm}$. The mean $\mathrm{pH}$ at the upstream site was 6.5 and 6.6 downstream. These $\mathrm{pH}$ results were within the EPA allowable range of 6.0 to 9.0.

When analyzing the data for the pre-construction Morris permit, none of the testing parameters measured outside of the EPA limits. The major constituent concentrations found in flowback water were at minimal concentration for the up and downstream sites. Over the duration of the monitoring period, there was little fluctuation in the concentrations of the various testing constituents. From these results it could be determined that throughout this monitoring 
period there was no contribution to the streams from the preliminary well construction for the Daniel Morris permit.

The NRCCE results of the upstream sites for the active Edwin Bunner (active) permit are displayed in Table 6. The mean TDS measurement upstream was $60.55 \mathrm{mg} / \mathrm{L}$ and $43.50 \mathrm{mg} / \mathrm{L}$ downstream. Zero measurements exceeded the EPA limit of $500 \mathrm{mg} / \mathrm{L}$. The mean sodium concentration upstream was $0.89 \mathrm{mg} / \mathrm{L}$ and $0.80 \mathrm{mg} / \mathrm{L}$ downstream. Zero measurements exceeded the EPA limit of $100 \mathrm{mg} / \mathrm{L}$. The hardness for the upstream sites had a mean calcium concentration of $6.59 \mathrm{mg} / \mathrm{L}$ and $3.82 \mathrm{mg} / \mathrm{L}$, and a mean magnesium concentration of $2.38 \mathrm{mg} / \mathrm{L}$ and $1.62 \mathrm{mg} / \mathrm{L}$. Neither ion concentration was high enough to cause any water quality concerns. The mean chloride for the collected upstream samples were $2.73 \mathrm{mg} / \mathrm{L}$ and $1.63 \mathrm{mg} / \mathrm{L}$ with none of the concentrations exceeding the EPA limit of $250 \mathrm{mg} / \mathrm{L}$.

Table 6. NRCCE Lab analysis for the sampling sites located upstream of the Edwin Bunner (active) permit.

\begin{tabular}{|c|c|c|c|c|c|c|c|c|c|c|}
\hline $\begin{array}{c}\text { Edwin Bunner Construction } \\
\text { Site } 5 \text { Laurel Run Southeast (Lrn SE) }\end{array}$ & $\begin{array}{l}\text { EC (lab) } \\
(\mu \mathrm{s} / \mathrm{cm})\end{array}$ & Alk & $\mathrm{Lab} \mathrm{pH}$ & $\begin{array}{c}\mathrm{Br} \\
(\mathrm{mg} / \mathrm{L})\end{array}$ & $\begin{array}{c}\mathrm{Al} \\
(\mathrm{mg} / \mathrm{L})\end{array}$ & $\begin{array}{l}\text { D. Al } \\
(\mathrm{mg} / \mathrm{L})\end{array}$ & $\begin{array}{r}\mathrm{Fe} \\
(\mathrm{mg} / \mathrm{L})\end{array}$ & $\begin{array}{c}\text { D. Fe } \\
(\mathrm{mg} / \mathrm{L})\end{array}$ & $\begin{array}{r}\mathrm{Mn} \\
(\mathrm{mg} / \mathrm{L})\end{array}$ & $\begin{array}{l}\text { D. Mn } \\
(\mathrm{mg} / \mathrm{L})\end{array}$ \\
\hline Detectable Limit & 2.2 & 1 & & 0.088 & 0.1 & 0.1 & 0.1 & 0.1 & 0.1 & 0.1 \\
\hline Number of Detectable Samples & 11 & 12 & 12 & 2 & 1 & 0 & 0 & 0 & 0 & 4 \\
\hline Mean & 68.99 & 24.59 & 6.48 & 0.10 & 0.11 & - & - & - & - & 2.85 \\
\hline STD & 36.89 & 20.13 & 0.53 & 0.01 & & - & - & - & - & 2.55 \\
\hline Min & 37.30 & 4.82 & 5.65 & 0.10 & 0.11 & - & - & - & - & 0.50 \\
\hline Max & 126.00 & 60.41 & 7.33 & 0.11 & 0.11 & - & - & - & - & 5.57 \\
\hline & $\begin{array}{c}\mathrm{S} \\
(\mathrm{mg} / \mathrm{L})\end{array}$ & $\begin{array}{c}\mathrm{Cl} \\
(\mathrm{mg} / \mathrm{L})\end{array}$ & $\begin{array}{c}\mathrm{Ca} \\
(\mathrm{mg} / \mathrm{L})\end{array}$ & $\begin{array}{l}\text { D. Ca } \\
(\mathrm{mg} / \mathrm{L})\end{array}$ & $\begin{array}{c}\mathrm{Na} \\
(\mathrm{mg} / \mathrm{L})\end{array}$ & $\begin{array}{c}\mathrm{Mg} \\
(\mathrm{mg} / \mathrm{L})\end{array}$ & $\begin{array}{l}\text { D. Mg } \\
(\mathrm{mg} / \mathrm{L})\end{array}$ & $\begin{array}{c}\mathrm{SO} 4 \\
(\mathrm{mg} / \mathrm{L})\end{array}$ & $\begin{array}{c}\text { TSS } \\
(\mathrm{mg} / \mathrm{L})\end{array}$ & $\begin{array}{r}\mathrm{TDS}_{\mathrm{G}} \\
(\mathrm{mg} / \mathrm{L})\end{array}$ \\
\hline Detectable Limit & 0.047 & 0.44 & 0.1 & 0.1 & 0.1 & 0.1 & 0.1 & 0.12 & 2.37 & 3.4 \\
\hline Number of Detectable Samples & 9 & 11 & 11 & 10 & 10 & 11 & 10 & 11 & 9 & 11 \\
\hline Mean & 4.81 & 2.73 & 6.59 & 5.16 & 0.89 & 2.38 & 1.87 & 18.32 & 20.22 & 60.55 \\
\hline STD & 5.94 & 2.11 & 3.58 & 3.58 & 0.55 & 1.12 & 1.25 & 9.89 & 19.38 & 24.23 \\
\hline Min & 0.35 & 0.76 & 2.47 & 2.10 & 0.24 & 0.89 & 0.54 & 10.10 & 4.00 & 38.00 \\
\hline Max & 16.40 & 6.94 & 12.97 & 11.73 & 1.84 & 4.28 & 4.08 & 42.00 & 58.00 & 104.00 \\
\hline Site 6 South Laurel Run (S Lrn) & $\begin{array}{c}\text { EC (lab) } \\
(\mu \mathrm{s} / \mathrm{cm})\end{array}$ & Alk & Lab pH & $\begin{array}{c}\mathrm{Br} \\
(\mathrm{mg} / \mathrm{L}) \\
\end{array}$ & $\begin{array}{c}\mathrm{Al} \\
(\mathrm{mg} / \mathrm{L})\end{array}$ & $\begin{array}{l}\text { D. Al } \\
(\mathrm{mg} / \mathrm{L})\end{array}$ & $\begin{array}{r}\mathrm{Fe} \\
(\mathrm{mg} / \mathrm{L})\end{array}$ & $\begin{array}{c}\text { D. Fe } \\
(\mathrm{mg} / \mathrm{L})\end{array}$ & $\begin{array}{r}\mathrm{Mn} \\
(\mathrm{mg} / \mathrm{L}) \\
\end{array}$ & $\begin{array}{l}\text { D. Mn } \\
(\mathrm{mg} / \mathrm{L})\end{array}$ \\
\hline Detectable Limit & 2.2 & 1 & & 0.088 & 0.1 & 0.1 & 0.1 & 0.1 & 0.1 & 0.1 \\
\hline Number of Detectable Samples & 12 & 12 & 12 & 2 & 1 & 0 & 3 & 2 & 3 & 3 \\
\hline Mean & 46.11 & 13.69 & 6.55 & 0.18 & 0.17 & - & 0.47 & 0.26 & 1.36 & 1.52 \\
\hline STD & 5.97 & 8.45 & 0.67 & 0.07 & & - & 0.59 & 0.09 & 2.08 & 1.80 \\
\hline Min & 40.20 & 4.07 & 5.61 & 0.13 & 0.17 & - & 0.12 & 0.19 & 0.14 & 0.19 \\
\hline Max & 60.30 & 31.90 & 7.85 & 0.23 & 0.17 & - & 1.15 & 0.32 & 3.77 & 3.57 \\
\hline & $\begin{array}{c}\mathrm{S} \\
(\mathrm{mg} / \mathrm{L}) \\
\end{array}$ & $\begin{array}{c}\mathrm{Cl} \\
(\mathrm{mg} / \mathrm{L}) \\
\end{array}$ & $\begin{array}{c}\mathrm{Ca} \\
(\mathrm{mg} / \mathrm{L}) \\
\end{array}$ & $\begin{array}{l}\text { D. Ca } \\
(\mathrm{mg} / \mathrm{L})\end{array}$ & $\begin{array}{c}\mathrm{Na} \\
(\mathrm{mg} / \mathrm{L})\end{array}$ & $\begin{array}{c}\mathrm{Mg} \\
(\mathrm{mg} / \mathrm{L})\end{array}$ & $\begin{array}{l}\text { D. Mg } \\
(\mathrm{mg} / \mathrm{L})\end{array}$ & $\begin{array}{c}\mathrm{SO} 4 \\
(\mathrm{mg} / \mathrm{L})\end{array}$ & $\begin{array}{c}\text { TSS } \\
(\mathrm{mg} / \mathrm{L}) \\
\end{array}$ & $\begin{array}{r}\mathrm{TDS}_{\mathrm{G}} \\
(\mathrm{mg} / \mathrm{L})\end{array}$ \\
\hline Detectable Limit & 0.047 & 0.44 & 0.1 & 0.1 & 0.1 & 0.1 & 0.1 & 0.12 & 2.37 & 3.4 \\
\hline Number of Detectable Samples & 11 & 12 & 12 & 11 & 10 & 12 & 11 & 12 & 7 & 12 \\
\hline Mean & 5.06 & 1.63 & 3.82 & 3.50 & 0.80 & 1.62 & 1.38 & 13.06 & 17.14 & 43.50 \\
\hline STD & 5.27 & 1.21 & 0.80 & 0.93 & 0.30 & 0.36 & 0.49 & 2.06 & 14.23 & 9.77 \\
\hline Min & 1.68 & 0.85 & 2.60 & 2.10 & 0.39 & 0.98 & 0.45 & 10.30 & 6.00 & 26.00 \\
\hline Max & 15.70 & 4.91 & 5.26 & 5.28 & 1.30 & 2.11 & 2.07 & 16.90 & 48.00 & 60.00 \\
\hline
\end{tabular}


The mean sulfate concentrations for the upstream sites were $18.32 \mathrm{mg} / \mathrm{L}$ and $13.06 \mathrm{mg} / \mathrm{L}$. None of the measurements exceeded the SDWA limit of $250 \mathrm{mg} / \mathrm{L}$. There were only four total detectable samples for the constituent bromide, whose mean values were $0.10 \mathrm{mg} / \mathrm{L}$ and 0.18 $\mathrm{mg} / \mathrm{L}$. The laboratory measurement for upstream mean conductivity was $68.99 \mu \mathrm{S} / \mathrm{cm}$ and 46.11 $\mu \mathrm{S} / \mathrm{cm}$, both were well below the parameter limit of $500 \mu \mathrm{S} / \mathrm{cm}$. The mean $\mathrm{pH}$ was 6.59 and 6.55, which was within the EPA allowable range of 6.0 to 9.0.

The NRCCE results of the downstream sites for the active Edwin Bunner permit are displayed in Table 7. The mean TDS measurements were $103.0 \mathrm{mg} / \mathrm{L}$ and $92.0 \mathrm{mg} / \mathrm{L}$, with zero measurements exceeding the EPA limit of $500 \mathrm{mg} / \mathrm{L}$. The mean sodium concentrations were 1.69 $\mathrm{mg} / \mathrm{L}$ and $1.43 \mathrm{mg} / \mathrm{L}$. Zero measurements exceeded the EPA limit of $100 \mathrm{mg} / \mathrm{L}$. The hardness for the upstream sites were a mean calcium concentration of $20.4 \mathrm{mg} / \mathrm{L}$ and $21.1 \mathrm{mg} / \mathrm{L}$, and a mean magnesium concentration of $2.63 \mathrm{mg} / \mathrm{L}$ and $2.69 \mathrm{mg} / \mathrm{L}$. Neither ion concentration was high enough to cause any water quality concerns. The mean chloride for the collected samples were $2.89 \mathrm{mg} / \mathrm{L}$ and $4.16 \mathrm{mg} / \mathrm{L}$, with none of the concentration exceeding the EPA limit of $250 \mathrm{mg} / \mathrm{L}$.

The mean sulfate concentrations for the upstream sites were $16.29 \mathrm{mg} / \mathrm{L}$ and $13.14 \mathrm{mg} / \mathrm{L}$. None of the measurements exceeded the SDWA limit of $250 \mathrm{mg} / \mathrm{L}$. There were only five total detectable samples for the constituent bromide, whose mean values were $0.11 \mathrm{mg} / \mathrm{L}$ and 6.34 $\mathrm{mg} / \mathrm{L}$. There was a bromide concentration of $12.55 \mathrm{mg} / \mathrm{L}$ at Ds Res. This outliner created a skewed mean concentration because there was only one other detectable concentration, 0.13 $\mathrm{mg} / \mathrm{L}$. The laboratory measurement for the mean conductivity was $141.6 \mu \mathrm{S} / \mathrm{cm}$ and 138.0 $\mu \mathrm{S} / \mathrm{cm}$, both were well below the parameter limit of $500 \mu \mathrm{S} / \mathrm{cm}$. The mean $\mathrm{pH}$ for the downstream sites was 6.71, which was within the EPA allowable range of 6.0 to 9.0. 
Table 7. NRCCE Lab analysis for the sampling sites located downstream of the Edwin Bunner (active) permit.

\begin{tabular}{|c|c|c|c|c|c|c|c|c|c|c|}
\hline $\begin{array}{c}\text { Edwin Bunner Construction } \\
\text { Site } 4 \text { Reservoir (Resv) }\end{array}$ & $\begin{array}{c}\text { EC (lab) } \\
(\mu \mathrm{s} / \mathrm{cm})\end{array}$ & Alk & $\mathrm{Lab} \mathrm{pH}$ & $\begin{array}{c}\mathrm{Br} \\
(\mathrm{mg} / \mathrm{L})\end{array}$ & $\begin{array}{c}\mathrm{Al} \\
(\mathrm{mg} / \mathrm{L})\end{array}$ & $\begin{array}{l}\text { D. Al } \\
(\mathrm{mg} / \mathrm{L})\end{array}$ & $\begin{array}{c}\mathrm{Fe} \\
(\mathrm{mg} / \mathrm{L})\end{array}$ & $\begin{array}{l}\text { D. Fe } \\
(\mathrm{mg} / \mathrm{L})\end{array}$ & $\begin{array}{r}\mathrm{Mn} \\
(\mathrm{mg} / \mathrm{L})\end{array}$ & $\begin{array}{l}\text { D. Mn } \\
(\mathrm{mg} / \mathrm{L})\end{array}$ \\
\hline Detectable Limit & 2.2 & 1 & & 0.088 & 0.1 & 0.1 & 0.1 & 0.1 & 0.1 & 0.1 \\
\hline Number of Detectable Samples & 12 & 12 & 12 & 3 & 2 & 0 & 7 & 4 & 4 & 6 \\
\hline Mean & 141.55 & 56.25 & 6.71 & 0.11 & 0.14 & - & 0.78 & 0.56 & 0.59 & 0.46 \\
\hline STD & 100.41 & 49.64 & 0.62 & 0.02 & 0.03 & - & 0.72 & 0.23 & 0.41 & 0.20 \\
\hline Min & 52.50 & 8.77 & 5.68 & 0.09 & 0.12 & - & 0.13 & 0.26 & 0.31 & 0.24 \\
\hline Max & 339.00 & 150.21 & 7.75 & 0.13 & 0.16 & - & 1.84 & 0.78 & 1.20 & 0.75 \\
\hline & $\begin{array}{c}\mathrm{S} \\
(\mathrm{mg} / \mathrm{L}) \\
\end{array}$ & $\begin{array}{c}\mathrm{Cl} \\
(\mathrm{mg} / \mathrm{L}) \\
\end{array}$ & $\begin{array}{c}\mathrm{Ca} \\
(\mathrm{mg} / \mathrm{L}) \\
\end{array}$ & $\begin{array}{l}\text { D. Ca } \\
(\mathrm{mg} / \mathrm{L})\end{array}$ & $\begin{array}{c}\mathrm{Na} \\
(\mathrm{mg} / \mathrm{L}) \\
\end{array}$ & $\begin{array}{c}\mathrm{Mg} \\
(\mathrm{mg} / \mathrm{L})\end{array}$ & $\begin{array}{l}\text { D. } \mathrm{Mg} \\
(\mathrm{mg} / \mathrm{L})\end{array}$ & $\begin{array}{c}\mathrm{SO} 4 \\
(\mathrm{mg} / \mathrm{L})\end{array}$ & $\begin{array}{c}\mathrm{TSS} \\
(\mathrm{mg} / \mathrm{L}) \\
\end{array}$ & $\begin{array}{r}\mathrm{TDS}_{\mathrm{G}} \\
(\mathrm{mg} / \mathrm{L})\end{array}$ \\
\hline Detectable Limit & 0.047 & 0.44 & 0.1 & 0.1 & 0.1 & 0.1 & 0.1 & 0.12 & 2.37 & 3.4 \\
\hline Number of Detectable Samples & 11 & 12 & 12 & 11 & 12 & 12 & 11 & 12 & 8 & 12 \\
\hline Mean & 5.33 & 2.89 & 20.40 & 16.39 & 1.69 & 2.63 & 2.21 & 16.29 & 9.96 & 103.00 \\
\hline STD & 4.27 & 1.26 & 17.34 & 17.44 & 1.05 & 1.08 & 1.35 & 6.91 & 7.98 & 66.96 \\
\hline Min & 2.04 & 1.36 & 4.40 & 3.00 & 0.61 & 1.19 & 0.83 & 11.30 & 2.37 & 38.00 \\
\hline Max & 16.40 & 4.94 & 53.57 & 49.90 & 4.43 & 5.22 & 5.30 & 36.80 & 24.00 & 244.00 \\
\hline Site 9 Downstream Reservoir (Ds Res) & $\begin{array}{c}\mathrm{EC} \mathrm{(lab)} \\
(\mu \mathrm{s} / \mathrm{cm})\end{array}$ & Alk & Lab pH & $\begin{array}{c}\mathrm{Br} \\
(\mathrm{mg} / \mathrm{L})\end{array}$ & $\begin{array}{c}\mathrm{Al} \\
(\mathrm{mg} / \mathrm{L})\end{array}$ & $\begin{array}{l}\text { D. Al } \\
(\mathrm{mg} / \mathrm{L})\end{array}$ & $\begin{array}{r}\mathrm{Fe} \\
(\mathrm{mg} / \mathrm{L})\end{array}$ & $\begin{array}{l}\text { D. Fe } \\
(\mathrm{mg} / \mathrm{L})\end{array}$ & $\begin{array}{r}\mathrm{Mn} \\
(\mathrm{mg} / \mathrm{L})\end{array}$ & $\begin{array}{l}\text { D. } \mathrm{Mn} \\
(\mathrm{mg} / \mathrm{L})\end{array}$ \\
\hline Detectable Limit & 2.2 & 1 & & 0.088 & 0.1 & 0.1 & 0.1 & 0.1 & 0.1 & 0.1 \\
\hline Number of Detectable Samples & 12 & 12 & 12 & 2 & 1 & 0 & 1 & 0 & 1 & 1 \\
\hline Mean & 137.98 & 57.97 & 6.71 & 6.34 & 0.11 & - & 0.16 & - & 0.20 & 0.20 \\
\hline STD & 70.14 & 39.50 & 0.55 & 8.78 & & - & 0.16 & - & 0.20 & 0.20 \\
\hline Min & 64.40 & 17.21 & 5.81 & 0.13 & 0.11 & - & 0.16 & - & 0.20 & 0.20 \\
\hline Max & 271.00 & 130.66 & 7.68 & 12.55 & 0.11 & - & 0.16 & - & 0.20 & 0.20 \\
\hline & $\begin{array}{c}\mathrm{S} \\
(\mathrm{mg} / \mathrm{L})\end{array}$ & $\begin{array}{c}\mathrm{Cl} \\
(\mathrm{mg} / \mathrm{L})\end{array}$ & $\begin{array}{c}\mathrm{Ca} \\
(\mathrm{mg} / \mathrm{L})\end{array}$ & $\begin{array}{l}\text { D. Ca } \\
(\mathrm{mg} / \mathrm{L})\end{array}$ & $\begin{array}{c}\mathrm{Na} \\
(\mathrm{mg} / \mathrm{L})\end{array}$ & $\begin{array}{c}\mathrm{Mg} \\
(\mathrm{mg} / \mathrm{L})\end{array}$ & $\begin{array}{l}\text { D. Mg } \\
(\mathrm{mg} / \mathrm{L})\end{array}$ & $\begin{array}{c}\mathrm{SO} 4 \\
(\mathrm{mg} / \mathrm{L})\end{array}$ & $\begin{array}{c}\text { TSS } \\
(\mathrm{mg} / \mathrm{L})\end{array}$ & $\begin{array}{r}\mathrm{TDS}_{\mathrm{G}} \\
(\mathrm{mg} / \mathrm{L})\end{array}$ \\
\hline Detectable Limit & 0.047 & 0.44 & 0.1 & 0.1 & 0.1 & 0.1 & 0.1 & 0.12 & 2.37 & 3.4 \\
\hline Number of Detectable Samples & 12 & 12 & 12 & 11 & 11 & 12 & 11 & 12 & 5 & 12 \\
\hline Mean & 4.39 & 4.16 & 21.06 & 18.97 & 1.43 & 2.69 & 2.24 & 13.14 & 8.40 & 92.00 \\
\hline STD & 3.93 & 5.15 & 12.03 & 13.37 & 0.63 & 0.92 & 1.23 & 1.57 & 4.34 & 38.82 \\
\hline Min & 0.35 & 1.36 & 7.40 & 5.20 & 0.66 & 1.28 & 0.67 & 10.70 & 6.00 & 48.00 \\
\hline Max & 15.50 & 19.98 & 43.62 & 44.09 & 2.82 & 4.49 & 4.31 & 16.10 & 16.00 & 164.00 \\
\hline
\end{tabular}

When comparing the upstream to downstream sites at the active Edwin Bunner (active) permit a few conclusions were formulated. The downstream sites produced higher mean concentrations of TDS, sodium, calcium, magnesium, chloride, bromide, conductivity, and $\mathrm{pH}$. The mean sulfate concentration was the only constituent that was not greater downstream than upstream. Even with most of the ion concentrations higher downstream, all concentrations are below their respective EPA standards limit. While measureable differences were noted, water quality at the downstream site is not of concern.

The NRCCE results of the upstream and downstream sites for the inactive Orthodox Church Society (inactive) permit are displayed in Table 8. The mean TDS measured $90.18 \mathrm{mg} / \mathrm{L}$ at WDS and $73.50 \mathrm{mg} / \mathrm{L}$ at WD CHRY Rd with zero measurements exceeding the EPA limit of $500 \mathrm{mg} / \mathrm{L}$. The mean sodium concentration was $6.94 \mathrm{mg} / \mathrm{L}$ at WDS, and $4.16 \mathrm{mg} / \mathrm{L}$ at WD CHRY Rd. Zero measurement exceeded the EPA limit of $100 \mathrm{mg} / \mathrm{L}$. 
Table 8. NRCCE Lab analysis for the sampling sites located up and downstream of the Orthodox Church Society (inactive) permit.

\begin{tabular}{|c|c|c|c|c|c|c|c|c|c|c|}
\hline $\begin{array}{c}\text { Edwin Bunner Construction } \\
\text { Site } 8 \text { Whiteday Creek South (WDS) } \\
\end{array}$ & $\begin{array}{l}\text { EC (lab) } \\
(\mu \mathrm{s} / \mathrm{cm})\end{array}$ & Alk & $\mathrm{Lab} \mathrm{pH}$ & $\begin{array}{c}\mathrm{Br} \\
(\mathrm{mg} / \mathrm{L}) \\
\end{array}$ & $\begin{array}{c}\mathrm{Al} \\
(\mathrm{mg} / \mathrm{L}) \\
\end{array}$ & $\begin{array}{l}\text { D. Al } \\
(\mathrm{mg} / \mathrm{L})\end{array}$ & $\begin{array}{r}\mathrm{Fe} \\
(\mathrm{mg} / \mathrm{L}) \\
\end{array}$ & $\begin{array}{r}\text { D. Fe } \\
(\mathrm{mg} / \mathrm{L})\end{array}$ & $\begin{array}{r}\mathrm{Mn} \\
(\mathrm{mg} / \mathrm{L}) \\
\end{array}$ & $\begin{array}{l}\mathrm{D} . \mathrm{Mn} \\
(\mathrm{mg} / \mathrm{L})\end{array}$ \\
\hline \multirow{14}{*}{$\begin{array}{r}\text { Detectable Limit } \\
\text { Number of Detectable Samples } \\
\text { Mear } \\
\text { STD } \\
\text { Mir } \\
\text { Max } 7 \text { Whiteday Cherry Run Road } \\
\text { (WD CHRY RD) }\end{array}$} & 2.2 & 1 & & 0.088 & 0.1 & 0.1 & 0.1 & 0.1 & 0.1 & 0.1 \\
\hline & 11 & 11 & 11 & 1 & 3 & 0 & 11 & 10 & 4 & 5 \\
\hline & 135.91 & 42.76 & 6.63 & 0.30 & 0.37 & & 1.15 & 0.64 & 0.55 & 0.43 \\
\hline & 47.78 & 22.47 & 0.53 & & 0.38 & & 0.88 & 0.50 & 0.20 & 0.23 \\
\hline & 67.40 & 13.66 & 5.79 & 0.30 & 0.13 & & 0.27 & 0.15 & 0.33 & 0.13 \\
\hline & 197.30 & 81.56 & 7.51 & 0.30 & 0.81 & & 2.92 & 1.43 & 0.77 & 0.68 \\
\hline & $\begin{array}{c}\mathrm{S} \\
(\mathrm{mg} / \mathrm{L})\end{array}$ & $\begin{array}{c}\mathrm{Cl} \\
(\mathrm{mg} / \mathrm{L})\end{array}$ & $\begin{array}{c}\mathrm{Ca} \\
(\mathrm{mg} / \mathrm{L})\end{array}$ & $\begin{array}{l}\text { D. Ca } \\
\text { (mg/L) }\end{array}$ & $\begin{array}{c}\mathrm{Na} \\
(\mathrm{mg} / \mathrm{L})\end{array}$ & $\begin{array}{c}\mathrm{Mg} \\
(\mathrm{mg} / \mathrm{L})\end{array}$ & $\begin{array}{l}\text { D. } \mathrm{Mg} \\
(\mathrm{mg} / \mathrm{L})\end{array}$ & $\begin{array}{c}\mathrm{SO} 4 \\
(\mathrm{mg} / \mathrm{L})\end{array}$ & $\begin{array}{c}\text { TSS } \\
(\mathrm{mg} / \mathrm{L})\end{array}$ & $\begin{array}{r}\mathrm{TDS}_{\mathrm{G}} \\
(\mathrm{mg} / \mathrm{L})\end{array}$ \\
\hline & 0.047 & 0.44 & 0.1 & 0.1 & 0.1 & 0.1 & 0.1 & 0.12 & 2.37 & 3.4 \\
\hline & 10 & 11 & 11 & 10 & 10 & 11 & 10 & 11 & 10 & 11 \\
\hline & 3.08 & 12.87 & 11.99 & 10.66 & 6.94 & 2.68 & 2.22 & 14.00 & 12.00 & 90.18 \\
\hline & 5.82 & 5.86 & 4.38 & 5.03 & 2.81 & 0.68 & 0.94 & 2.79 & 6.39 & 31.67 \\
\hline & 0.05 & 7.42 & 5.11 & 4.23 & 3.08 & 1.24 & 0.98 & 10.60 & 4.00 & 44.00 \\
\hline & 19.50 & 27.13 & 18.48 & 18.80 & 12.14 & 3.68 & 3.71 & 18.70 & 22.00 & 128.00 \\
\hline & $\begin{array}{c}\text { EC (lab) } \\
(\mu s / c m)\end{array}$ & Alk & $\mathrm{Lab} \mathrm{pH}$ & $\begin{array}{c}\mathrm{Br} \\
(\mathrm{mg} / \mathrm{L})\end{array}$ & $\begin{array}{c}\mathrm{Al} \\
(\mathrm{mg} / \mathrm{L})\end{array}$ & $\begin{array}{l}\text { D. Al } \\
(\mathrm{mg} / \mathrm{L})\end{array}$ & $\begin{array}{c}\mathrm{Fe} \\
(\mathrm{mg} / \mathrm{L})\end{array}$ & $\begin{array}{c}\text { D. Fe } \\
(\mathrm{mg} / \mathrm{L})\end{array}$ & $\begin{array}{r}\mathrm{Mn} \\
(\mathrm{mg} / \mathrm{L})\end{array}$ & $\begin{array}{l}\text { D. Mn } \\
(\mathrm{mg} / \mathrm{L})\end{array}$ \\
\hline Detectable Limit & 2.2 & 1 & & 0.088 & 0.1 & 0.1 & 0.1 & 0.1 & 0.1 & 0.1 \\
\hline Number of Detectable Samples & 12 & 12 & 12 & 2 & 3 & 0 & 11 & 10 & 3 & 3 \\
\hline Mean & 101.18 & 34.01 & 6.61 & 0.17 & 0.17 & & 0.72 & 0.46 & 0.60 & 0.67 \\
\hline STD & 33.49 & 20.18 & 0.55 & 0.06 & 0.03 & & 0.49 & 0.37 & 0.82 & 0.75 \\
\hline Min & 61.50 & 10.82 & 5.75 & 0.13 & 0.14 & & 0.30 & 0.12 & 0.11 & 0.12 \\
\hline Max & 174.80 & 82.25 & 7.58 & 0.22 & 0.20 & & 1.67 & 1.15 & 1.55 & 1.53 \\
\hline & $\begin{array}{c}\mathrm{S} \\
(\mathrm{mg} / \mathrm{L}) \\
\end{array}$ & $\begin{array}{c}\mathrm{Cl} \\
(\mathrm{mg} / \mathrm{L})\end{array}$ & $\begin{array}{c}\mathrm{Ca} \\
(\mathrm{mg} / \mathrm{L})\end{array}$ & $\begin{array}{l}\text { D. Ca } \\
(\mathrm{mg} / \mathrm{L})\end{array}$ & $\begin{array}{c}\mathrm{Na} \\
(\mathrm{mg} / \mathrm{L})\end{array}$ & $\begin{array}{c}\mathrm{Mg} \\
(\mathrm{mg} / \mathrm{L})\end{array}$ & $\begin{array}{l}\text { D. } \mathrm{Mg} \\
(\mathrm{mg} / \mathrm{L})\end{array}$ & $\begin{array}{c}\mathrm{SO} 4 \\
(\mathrm{mg} / \mathrm{L}) \\
\end{array}$ & $\begin{array}{c}\text { TSS } \\
(\mathrm{mg} / \mathrm{L})\end{array}$ & $\begin{array}{r}\mathrm{TDS}_{\mathrm{G}} \\
(\mathrm{mg} / \mathrm{L})\end{array}$ \\
\hline Detectable Limit & 0.047 & 0.44 & 0.1 & 0.1 & 0.1 & 0.1 & 0.1 & 0.12 & 2.37 & 3.4 \\
\hline Number of Detectable Samples & 10 & 12 & 12 & 11 & 12 & 12 & 11 & 12 & 11 & 12 \\
\hline Mean & 4.61 & 5.77 & 9.77 & 8.83 & 4.16 & 2.26 & 1.89 & 13.12 & 8.18 & 73.50 \\
\hline STD & 6.22 & 2.76 & 4.17 & 5.06 & 1.12 & 0.48 & 0.80 & 1.86 & 3.84 & 19.45 \\
\hline Min & 0.56 & 1.57 & 4.80 & 3.20 & 2.81 & 1.46 & 0.84 & 10.70 & 4.00 & 46.00 \\
\hline $\operatorname{Max}$ & 18.40 & 9.10 & 20.33 & 20.53 & 6.78 & 3.14 & 3.23 & 17.20 & 16.00 & 110.00 \\
\hline
\end{tabular}

The hardness for the upstream site had a mean calcium concentration of $9.77 \mathrm{mg} / \mathrm{L}$ and a mean magnesium concentration of $2.26 \mathrm{mg} / \mathrm{L}$. The hardness of the downstream site was a mean calcium concentration of $11.99 \mathrm{mg} / \mathrm{L}$, and $2.68 \mathrm{mg} / \mathrm{L}$ mean magnesium concentration. Neither ion concentration was high enough to cause any water quality concerns. The mean chloride for the collected samples were $12.87 \mathrm{mg} / \mathrm{L}$ and $5.77 \mathrm{mg} / \mathrm{L}$ with none of the concentrations exceeding the EPA limit of $250 \mathrm{mg} / \mathrm{L}$. The mean sulfate concentration for the upstream site was $14.0 \mathrm{mg} / \mathrm{L}$ and $13.12 \mathrm{mg} / \mathrm{L}$ at the downstream. None of the measurements exceeded the SDWA limit of 250 $\mathrm{mg} / \mathrm{L}$. There were only 3 total detectable samples for the constituent bromide, one upstream and two downstream. The mean bromide concentrations were $0.30 \mathrm{mg} / \mathrm{L}$ and $0.17 \mathrm{mg} / \mathrm{L}$. The laboratory measurement for the mean conductivity was $135.91 \mu \mathrm{S} / \mathrm{cm}$ and $101.18 \mu \mathrm{S} / \mathrm{cm}$. Both were well below the parameter limit of $500 \mu \mathrm{S} / \mathrm{cm}$. The mean $\mathrm{pH}$ was 6.63 and 6.61, which was within the EPA allowable range of 6.0 to 9.0. 
The results for inactive Orthodox Church Society permit differed from the active and preconstruction permit. The results produced higher upstream ion concentrations and conductivities when compared to the downstream site. The outcomes could be a result of the US Route $119 \mathrm{~S}$. This transportation route crosses over the stream several hundred yards upstream from monitoring WDS. Typical highway maintenance and sheet flow runoff created could create the increase in upstream concentrations. However, the results were not affected by drilling practices due to the inactivity of the Orthodox Church Society permit.

\subsection{Calculated TDS}

The calculated total dissolved solids (TDS) are derived from the NRCCE Laboratory water sample results. It is formulated from the total sulfates, magnesium, calcium, sodium, chloride, and bicarbonates. For this study, $0.6 \mathrm{x}$ alkalinity was substituted for the bicarbonates (Water Environmental Federation 1995). This method of calculated TDS was chosen for analysis because it highlights the major anion/cations associated with flowback water.

Figure 17 illustrates the calculated TDS for the Daniel Morris (pre-construction) permit. For the majority of the monitoring period, there were slightly higher ion concentrations at Lck $\mathrm{N}$ than S Lck. The difference in ion concentrations increased through the warmer temperatures of the summer months. The higher concentration during this time was mainly associated with a change in calcium and alkalinity concentrations. The concentrations were two times or greater downstream than upstream. The final upstream water sample collected on August 30, 2012, was composed of: alkalinity $=27.36 \mathrm{mg} / \mathrm{L}$, calcium $=12.95 \mathrm{mg} / \mathrm{L}$, and total TDS $=55.84 \mathrm{mg} / \mathrm{L}$. The downstream sample for the same date was composed of: alkalinity $=63.12 \mathrm{mg} / \mathrm{L}$, calcium $=$ $35.05 \mathrm{mg} / \mathrm{L}$, and total TDS $=121.19 \mathrm{mg} / \mathrm{L}$. With this comparison, there is still no apparent concern with water quality. If the major ion concentrations of flowback water were to enter the stream, it would be expected that the concentrations for those ions should be elevated more than the results recorded from this project. However, slight increases to ion concentrations could have resulted from minimal traces of flowback water entering the stream. 

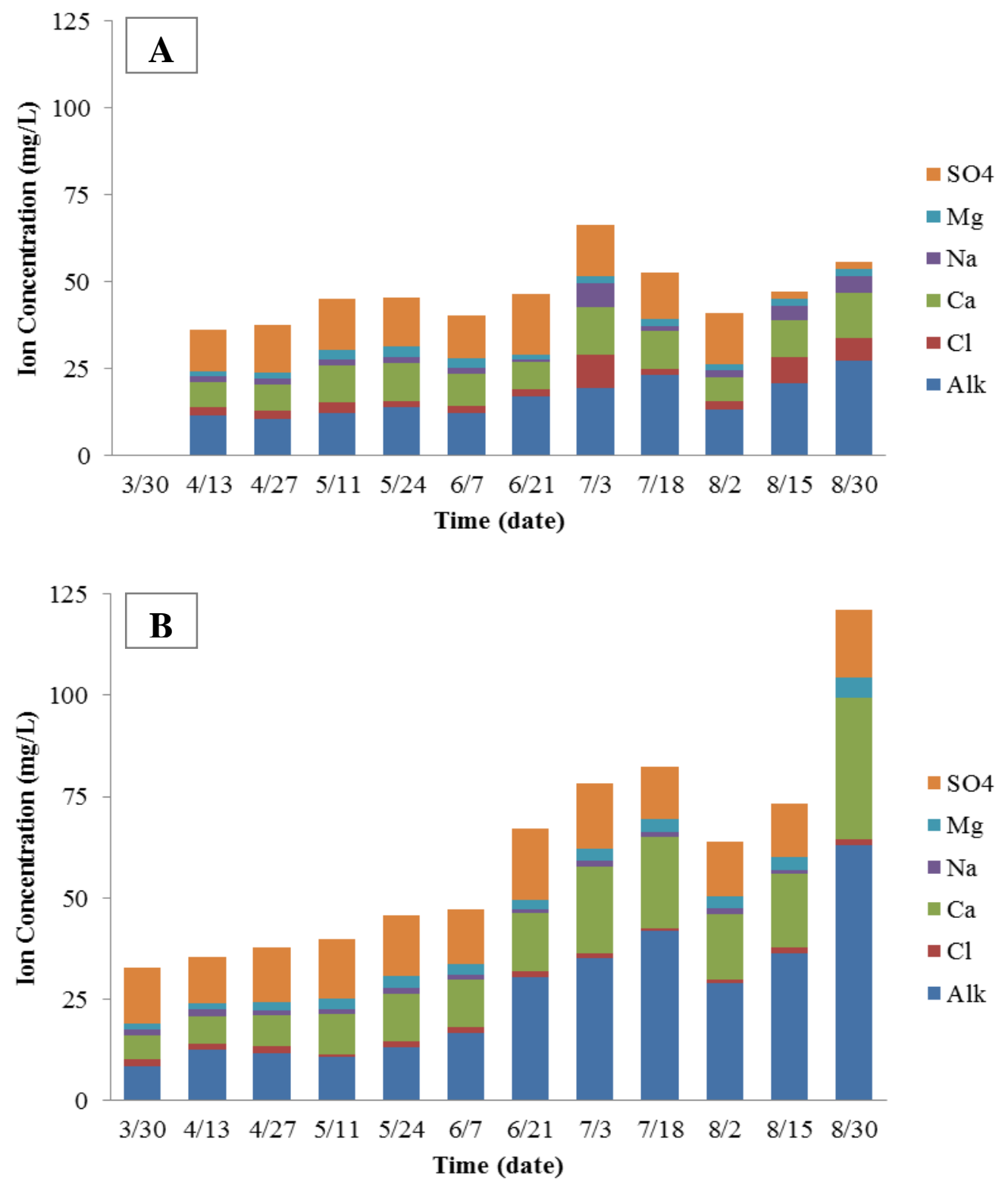

Figure 17. Calculated TDS (mg/L) from NRCCE analysis lab for teh Daniel Morris (Pre-construction) Permit field sites: A) S Lck and B) Lck N.

Figure 18 and Figure 19 display the calculated TDS for the Edwin Bunner (active) permit. Parts A and B of Figure 18 illustrate the calculated TDS for the upstream sites, Lrn SE and S Lrn, while parts C and D of Figure 19 are the calculated TDS for the downstream sites, Resv and Ds Res. The results of upstream sites varied slightly. Results for Lrn SE increased over the duration of the sampling period, while total TDS ion concentrations were still below 100.0 $\mathrm{mg} / \mathrm{L}$. The TDS for this site when ion concentrations increased was composed primarily of sulfates, calcium, and alkalinity. At S Lrn, the ion concentrations were less than $45.0 \mathrm{mg} / \mathrm{L}$ for 
the entire monitoring period. In addition, the concentration for each individual ion was constant with time.
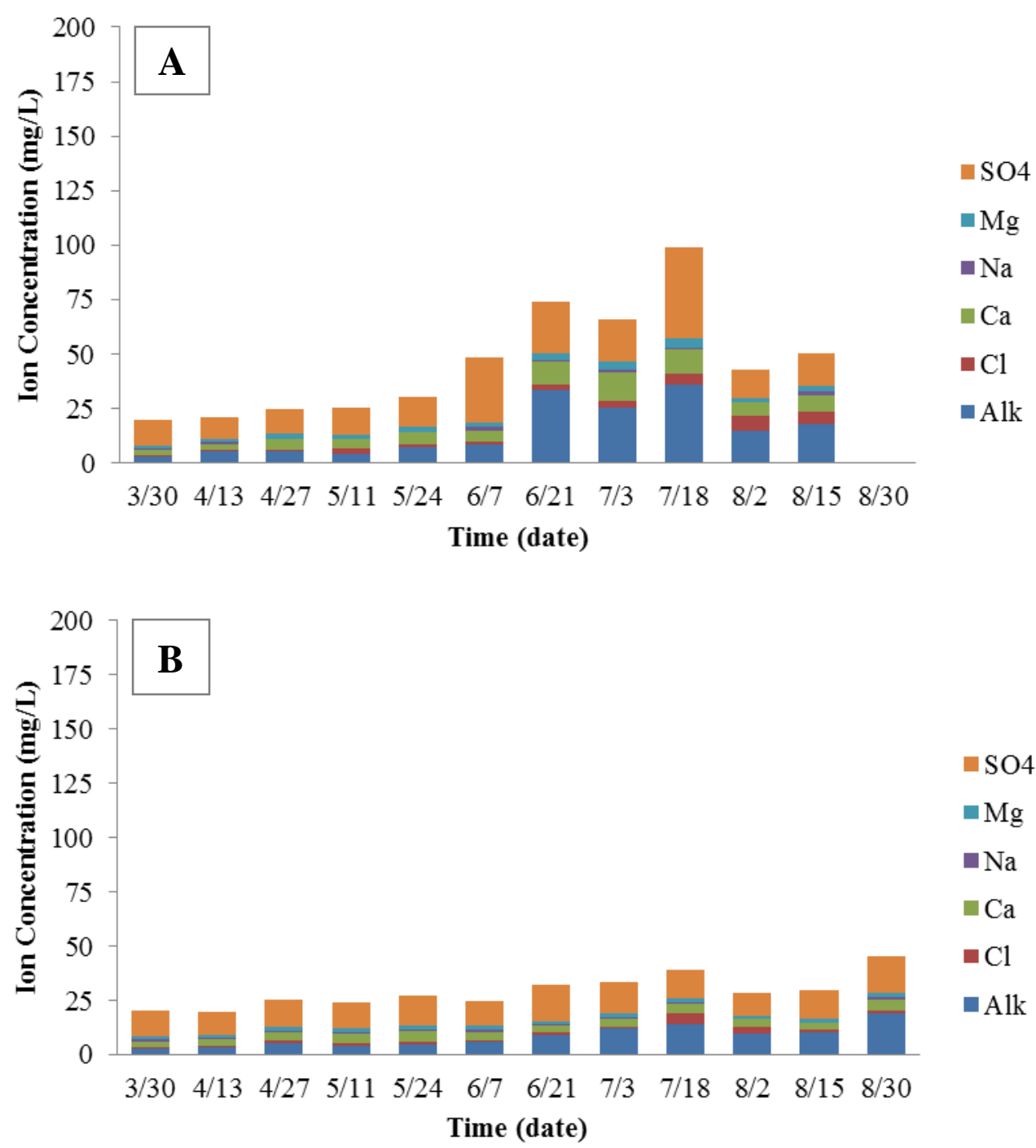

Figure 18. Calculated upstream TDS (mg/L) from NRCCE analysis lab for the Edwin Bunner (active) Permit active field sites: A) Lrn SE and B) S Lrn. 



Figure 19. Calculated downstream TDS (mg/L) from NRCCE analysis lab for the Edwin Bunner (active) Permit field sites: C) Resv and D) Ds Res.

The TDS from the Edwin Bunner downstream sites (Figure $19 \mathrm{C}$ and D) resemble the results from the downstream location of the Morris permit. Ion concentrations for the first half of the monitoring period stayed relatively c, TDS at the Resv site was less than $35.0 \mathrm{mg} / \mathrm{L}$, and TDS at the Ds Res sites was less than $57.5 \mathrm{mg} / \mathrm{L}$. However, during the summer months the calcium and alkalinity concentrations increased nearly five times. The calcium and alkalinity concentrations at Resv increased from $9.96 \mathrm{mg} / \mathrm{L}$ to $29.0 \mathrm{mg} / \mathrm{L}$ and from $12.4 \mathrm{mg} / \mathrm{L}$ to 50.7 $\mathrm{mg} / \mathrm{L}$, respectively. Likewise, at Ds Res, the calcium concentration increased from $5.82 \mathrm{mg} / \mathrm{L}$ to $30.8 \mathrm{mg} / \mathrm{L}$; alkalinity increased from $7.30 \mathrm{mg} / \mathrm{L}$ to $52.6 \mathrm{mg} / \mathrm{L}$. A slight fluctuation occurred in 
the other ion concentrations during the monitoring period. In addition, the downstream results illustrated nearly identical responses to upstream results in ion concentrations per sampling date. During sampling dates June 7 to August 30, each ion concentration for Figure 19 C mirrored the fluctuating response of Figure 19 D. Comparing the upstream sites to the downstream sites, results varied in the summer months. The upstream sites had a maximum TDS of $99.1 \mathrm{mg} / \mathrm{L}$, while the downstream sites maximum TDS was $178.5 \mathrm{mg} / \mathrm{L}$. These measurements indicate an increased TDS below the Bunner permit, however the TDS was still well below the EPA standard limit of $500 \mathrm{mg} / \mathrm{L}$.

The Orthodox Church Society (inactive) permit resulted in a calculated TDS (Figure 20) that was different than the two permits previously discussed. Increased larger ion concentrations of sodium and chloride were observed. The ion concentrations were not considered to impact the overall stream water quality. However, it is important to note that this permit is inactive, and no Marcellus operations have occurred that would affect these sites. The high concentrations should be considered with future analysis of water quality during the construction phase. A maximum sodium concentration of $9.57 \mathrm{mg} / \mathrm{L}$, only $10 \%$ of the EPA limit of $100 \mathrm{mg} / \mathrm{L}$, was measured at WDS. The maximum measurement of chloride concentration was $17.0 \mathrm{mg} / \mathrm{L}$, which did not exceed the EPA standard of $250 \mathrm{mg} / \mathrm{L}$. A maximum sodium concentration of $12.1 \mathrm{mg} / \mathrm{L}$ and a maximum chloride concentration of $27.1 \mathrm{mg} / \mathrm{L}$ were measured at WD CHRY Rd. This elevated chloride concentration could be a result of the monitoring location. These sites are located near US route 119S. Additional sodium and chloride ions could occur due to the winter treatment that transportation routes receive. The overall calculated TDS for these sites did not exceed 110.0 $\mathrm{mg} / \mathrm{L}$. The additional ion concentrations for this permit were similar when compared to the other permits. 



Figure 20. Calculated TDS (mg/L) from NRCCE analysis lab for the Orthodox Church Society inactive field sites: A) WDS and B) WD CHRY RD.

\subsection{Grain size distribution}

Table 9 displays the grain size distribution from each of the monitoring sites. During the monitoring period a total of four grain size measurements were collected. The results of this test displayed the median particle size (D50) and the $84^{\text {th }}$ percentile (D84) of the sample collected. The D50 grain size ranged from $<2 \mathrm{~mm}$ to $67 \mathrm{~mm}$, while D84 ranged from $<2 \mathrm{~mm}$ to $230 \mathrm{~mm}$. These ranges illustrated monitoring sites to have a gravel stream bed. The grain size distributions deceased in value illustrating a sediment load into the stream bed. The sediment load was a result of the dry summer season and a rain event. The rain event caused the "flushing" phenomenon of the dry soil. Sediment was transported to the stream and settled on the stream bed. 
Table 9. Grain size distribution of field sites.

\begin{tabular}{cccccc}
\hline Location & \multicolumn{5}{c}{ Grain Size $(\mathrm{mm})$} \\
& & $5 / 24 / 2012$ & $07 / 03 / 2012$ & $08 / 02 / 2012$ & $08 / 30 / 2012$ \\
\hline Lck N* & D50 & 25 & 17 & 15 & 24 \\
& D84 & 230 & 150 & 87 & 130 \\
S Lck & D50 & 46 & 18 & 22 & 14 \\
& D84 & 130 & 61 & 110 & 77 \\
Ds Res* & D50 & 67 & 20 & 31 & 23 \\
& D84 & 220 & 130 & 130 & 110 \\
Resv* & D50 & 7.2 & 8.9 & 7.1 & $* *$ \\
& D84 & 20 & 50 & 32 & $* *$ \\
Lrn Se & D50 & 45 & 47 & 16 & $* *$ \\
& S84 Lrn & 86 & 87 & 63 & $* *$ \\
& D50 & 34 & 42 & 38 & 27 \\
Wd Chry Rd * & D84 & 76 & 110 & 97 & 110 \\
& D50 & 43 & 29 & 12 & 22 \\
WDS & D84 & 140 & 120 & 85 & 110 \\
& D50 & $<2$ & $<2$ & 1.4 & 1.4 \\
& D84 & $<2$ & $<2$ & 1.8 & 1.8 \\
\hline
\end{tabular}

* Downstream field sites

** No data available due to stream conditions 


\section{Ch. 5 Summary and Conclusions}

To determine if water quality in streams were impaired due to drilling the Marcellus shale, a monitoring plan was developed. The monitoring plan was executed from March to August, 2012 in the Whiteday Creek watershed located in West Virginia. The plan was composed of different water quality tests and laboratory analysis to monitor the following parameters: conductivity, turbidity, benthic collections, TDS, ion concentrations, and grain size distribution.

The temperature and $\mathrm{pH}$ results for each permitted site recorded no measurement that exceeded their respective EPA standard limit. Results of the conductivity concentration varied with temperature, stream conditions, and site location. However, none of the results exceeded the $500 \mu \mathrm{S} / \mathrm{cm}$ limit. The measurements of turbidity resulted in some values that exceeded the background turbidity limit and the 25 NTU limits which posed potential harmful conditions to aquatic life. These results were primarily focused around the active Edwin Bunner permit. The elevated turbidity levels were measured both up and downstream of the permit location. Contribution to these increased turbidity measurements at upstream sites were due to low water conditions and water temperatures. Turbidity at the reservoir site was elevated due to the runoff produced from the redesigned curve, which widened and lengthened the road surface.

Ion concentrations of chloride, sodium, magnesium, calcium, sulfate, and alkalinity did not exceed their respective EPA standard limit. Results from the Morris and Bunner permit produced higher ion concentration resulted downstream of the Morris and Bunner permit. Some ion concentrations were higher upstream than downstream at the Orthodox Church Society permit. This permit is inactive, meaning no Marcellus development, and indicates results that are near the magnitude of the other permit locations. Calculated TDS from the water analysis results also illustrated ion concentrations that were below standard limits for each monitoring site and permit.

The results of this study determined that water quality of the monitoring sites in the Whiteday Creek watershed were not impaired. Each testing parameter of the monitoring plan resulted in ion concentrations that did not exceed EPA standard limits. Turbidity measurements surrounding the active Edwin Bunner permit produced exceeding measurements but those measurements were not constant throughout the monitoring period and values returned to normal levels. Also, no correlation could be determined between the permits phases of development and 
water quality. Benthic macro invertebrate conditions ranged from marginal to sub-optimal water quality at each permit. This results in a healthy stream for diverse aquatic communities. Similar studies regarding water quality and Marcellus shale development should continue and be considered for future research. 


\section{Ch. 6 References}

Army Corps of Engineering (2006). "Unified Facilities Criteria: General provisions and geometric design for roads, streets, walks, and open storage areas." Office of the Chief of Engineers, United States Army.

Arnold, C. L., and Gibbons, C. J. (1996). "Impervious surface coverage: the emergence of a key environmental indicator.” Journal of the American Planning Association, 62(2), 243-258

Arnold, C., Boison, P., and Patton, C. (1982). "Sawmill Brook: An example of rapid geomorphic change related to urbanization.” Journal of Geology, 90, 155-66

Arthur, D., Bohm, B., and Layne, M. (2008). "Hydraulic fracturing considerations for natural gas wells of the Marcellus shale." The Ground Water Protection Council 2008, Cincinnati, OH, 1-16

Arthur, D. and Cornue, D. (2010). "Technologies reduce pad size, waste." The American Oil and Gas Reporter, 53(8), 94-99

Barron, J. J. and Ashton, C. (2005). "The effect of temperature on conductivity measurement." TSP 07 issue 2 <http://www.fisher.co.uk/phpfiles/techzone/pdfs/reagecontemp.pdf $>$.

Booth, D., and Jackson, R. (1994). "Urbanization of aquatic systems-degradation thresholds and the limits of mitigation." In Proceedings of the American Water Resources Association Conference. Jackson hole, WY: American Water Resources Association.

Brabec, E., Schulte, S., and Richards, P. (2002). "Impervious Surfaces and Water Quality: A review of current literature and its implications for watershed planning." Journal of Planning Literature, 16(4), 499-514

Burdette, W. (2011). "Natural gas industry creates jobs in West Virginia, Pennsylvania." The State Journal, West Virginia Media.

Carter, R. W. (1961). "Magnitude and frequency of floods in suburban areas." U.S. Geological Survey Paper. 424-B, B9-B11. Washington, DC: U.S. Geological Survey.

Considine, T., Watson, R., Entler, R., and Sparks, J. (2009). "An emerging giant: Prospects and economic impacts of developing the Marcellus shale natural gas play." The Pennsylvania State University College of Earth and Mineral Sciences Department of Energy and Mineral Engineering, Penn State University.

Delta Oil Field (2012). "Frac tanks and frac trailers manufacturing." Hy-tech Truck and Trailer Manufacturing LLC, http://fractrailers.com/, (August 21, 2012).

Department of Environmental Quality (2005). "Technical basis for revising turbidity criteria." Department of Environmental Quality Water Quality Division, 1-17, Portland, Oregon.

Engelder, T., and Lash, G. (2008), "Marcellus shale play's vast resource potential creating stir in Appalachia." The American Oil and Gas Reporter, 51(6), 76-87. 
EPA (2012). "What is conductivity and why is it important." U.S. Environmental Protection Agency, Washington, D.C., Section 5.9 Water: Monitoring \& Assessment.

EPA (1999), “Importance of Turbidity.” EPA Guidance Manual Turbidity Provisions, Section 7.

EPA (2003). “Analytical Method for Turbidity Measurement Method 180.1." Environmental monitoring systems laboratory office of research and development U.S. Environmental Protection Agency, Cincinnati, OH, 180.1.1 -180.1.10

EPA (2011). "A field-based aquatic life benchmark for conductivity in central Appalachian streams.” Environmental Protection Agency, Washington, D.C., EPA/600/R-10/023F.

EPA (2011). "Proceedings of the technical workshops of the hydraulic fracturing study: Chemical and analytical methods." Environmental Protection Agency, Washington, D.C., EPA/600/R-11/066.

Forman, R., and Alexander, L. (1998). "Roads and their major ecological effects." Annual Review of Ecology and Systematics, 29, 207-231.

Gillespie, T. (1993). "Effects of heavy-vehicle characteristics on pavement response and performance." Journal: National Cooperative Highway Research Program Report, 353, 1-126

Goeken,W., Halvorson, D., and Hanson, C. (2004). "Quality assurance project plan for Red River basin river watch program." Red River Watershed Management Board, Detroit Lakes, Minnesota, 1-22.

Harbor, J. (1994). "A practical method for estimating the impact of land use change on surface runoff, groundwater recharge, and wetland hydrology."American Planning Association 60, 1:95108.

Harper, J.A. (2008). "The Marcellus Shale - an Old "New" Gas Reservoir, in Pennsylvania." Geology: Pennsylvania Department of Conservation and Natural Resources, 38(1), 20.

Harrelson, C., Rawlins, C., Potyondy, J. (1994). "Stream Channel Reference Sites: An illustrated guide to field technique." U.S. Department of Agriculture, Forest Service, Rocky Mountain Forest and Range Experiment Station, Fort Collins, CO, 1-61

Hayes, T. (2009). "Sampling and analysis of water streams associated with the development of Marcellus shale gas." Final report to Marcellus shale coalition, Gas Technology Institue, Des Plaines, Il.

Helms, L. (2008). “Horizontal Drilling.” North Dakota Geological Survey, 35(1), 1-3.

Horner, R., Booth, D., Azous, A., and May, C. (1997). "Watershed determinants of ecosystem functioning." In Effects of Watershed Development and Management on Aquatic Ecosystems, L.A. Roesner, ed. NY: American Society of Civil Engineers. 
Jones, J., Swanson, F., Wemple, B., Synder, K. (2000). "Effects of roads on hydrology, geomorphology, and disturbance patches in stream networks." Conservation Biology 14, 76-85

Leopold, L. B. (1968). "Hydrology for urban planning, a guidebook on the hydrologic effects of urban land use.” U.S. Geological Survey Circular 554. Washington, DC: U.S. Department of the Interior.

Limburg, K., and Schmidt, R. (1990). "Patterns of fish spawning in Hudson River tributaries: response to an urban gradient?” Ecology 71(4), 1238-1245.

Manning, J.C. (1997). “The applied principles of hydrology." Upper Saddle River, New Jersey: Prentice Hall, Inc.

McCaffrey, S. (2011). "Water quality parameters and indicators." Namoi Catchment Management Authority, New South Wales, 1-6.

<http://www.namoi.cma.nsw.gov.au/factsheet_water_quality_parameters.pdf > (August 22, 2012)

Megahan, W., Wilson, M., and Monson, S.B. (2001). "Sediment from granite cutslopes on forest roads in Idaho." Earth Surface Processes and Landforms, 26, 153-163.

Mitchell, M. (2010). “Gas drilling: Impacts on Roads.” Cornell Law School Water Law Clinic, Ithaca, NY, 1-4

Montgomery, D.R. (1994). "Road surface drainage, channel initiation, and slope stability." Water Resources Research, 30(6), 1925-1932.

Morisawa, M., and LaFlure, E. (1979). "Hydraulic geometry stream equilibrium and urbanization. In Adjustments of the fluvial systems-Proceedings of the 10th annual Geomorphology Symposium Series, D. D. Rhodes and G. P. Williams, Binghamton, NY.

Nord, A., and Mortensen, D. (2010). "Use of limestone gravel on forested roads increases abundance of mircostegium vimineum." The Penn State University

MPCA (2008). "Turbidity: description, impact on water quality, sources, measurements- A general overview.” Minnesota Pollution Control Agency, St. Paul, MN, 1-2.

National Energy Technology Laboratory (2009). "Appalachian shale gas: Success in the Marcellus Brings renewed attention to NETL's past and present gas shale programs." U.S. Department of Energy, Pittsburg, PA, Summer 2009 issue.

National Energy Technology Laboratory (2010). "Well spacing and placement." U.S. Department of Energy, Pittsburg, PA, 1-32.

New Hampshire University (2007). "The impacts of impervious surfaces on water resources." New Hampshire Estuaries Project. 
Parshall, J. (2008). "Barnett shale tight-gas development." Journal of Petroleum Technology, $60(9), 48-55$

Penn State University (2011). "Marcellus shale wastewater issues in Pennsylvania- current and emerging treatment and disposal technologies." Penn State University \& Pennsylvania Water Resources Research Center, 1-9.

Penn State University (2010). "Maps and graphics, depth to Marcellus shale base." Penn State Marcellus Center for Outreach and Research. http://www.marcellus.psu.edu/resources/maps.php (Sept. 29, 2011)

Picker, L., (2011). "Vehicle weight and automotive fatalities." National Bureau of Economic Research, 2011, 4

Ross, B., and Dillaha, T. (1993). "Rainfall simulation/water quality monitoring for best management practice effectiveness evaluation." Division of Soil and Water Conservation, VA Department of Conservation and Historic Res., Richmond, VA

Schramm, E. 2011. "What is flowback, and how does it differ from produced water?" Institute for Energy and Environmental Research of Northeastern Pennsylvania Clearinghouse, WilkesBarre, PA http://energy.wilkes.edu/205.asp

Schueler, T. (1994). "The importance of imperviousness." Watershed Protection Techniques, $1(3), 100-111$

Schueler, T., and Galli, J., (1992). "Environmental impacts of stormwater ponds."Watershed Restoration Sourcebook. Washington, DC: Metropolitan Washington Council of Governments

Soeder, D. J., and Kappel, W. M. (2009). "Water resources and natural gas production from the Marcellus shale." USGS Fact Sheet, 2009-3032, 6

Soeder, Daniel J. (2010). “The Marcellus Shale: resources and reservations.” EOS, Transactions, American Geophysical Union, 91(32), 277-288.

State of West Virginia, Office of Oil and Natural Gas, Department of Environmental Protection. (2012). Well Work Permit Application. Well Location Restrictions. <http://www.dep.wv.gov/oiland-gas/Horizontal-permits/Horizontal\%20Well\%20Permit\%20Packet/Documents/Horizontal \%206A\%20Well\%20Permit\%20Packet.\%2008-08-2012.pdf > (September 4, 2012).

Tennant, D. (1975). "Instream flow regiments for fish, wildlife, and recreation and related environmental resources." US Fish and Wildlife Services, Washington, DC, 1(4), 6-10

Trombulak, S., and Frissell, C. (2000). "Review of ecological effects of roads on terrestrial and aquatic communities." Conservation Biology, 14: 18-30.

U.S. Department of Energy (2009). "Modern shale gas development in the United States: A primer." U.S. Department of Energy, Office of Fossil Energy, National Energy Technology Laboratory. 
USGS (2004). "Policy on the use of the FlowTracker for discharge measurements." Office of Surface Water, Technical Memorandum 2004.04., 1-8

Van Nostrand, J., Brannon, T., Shepherd, W. (2012). "Marcellus Shale Drilling Comparative White Paper: The Regulatory Approaches of New York, Ohio, Pennsylvania, and West Virginia." West Virginia Regulation of Marcellus Shale Drilling.

<http://energy.law.wvu.edu/r/download/130703>. (September 8, 2012).

Veil, J.A. (2010). "Management of water flowing to the surface from the well." U.S. Department of Energy, Office of Fossil Energy, National Energy Technology Laboratory, 1-59.

Water Environmental Federation (1995). "Standard methods for the examination of water and wastewater." $19^{\text {th }}$ edition, Washington, D.C.

Wemple, B., Jones, J., and Grant, G. (1996). "Channel network extension by logging roads in two basins, Western Cascades, Oregon.” Water Resources Bulletin, 32, 1195-1207.

Wolman, M.G. (1954). "A method of sampling coarse river-bed material.” Trans. American Geophysical Union, 35, 951-956.

WVDEP (2011). "Water resources series 2: Requirements governing water quality standards." WV Department of Environmental Protection, Charleston, WV, 47CRS2, 1-52

WVDEP (2011). "West Virginia save our streams program level-one standard operating procedures manual." West Virginia Department of Environmental Protection, Charleston, WV, $1-28$.

WVWRI (2012). “Mon River QUEST Project.” West Virginia University's National Research Center of Coal \& Energy. 〈http://www.monriverquest.com/ > (June 20, 2012) 
Appendix A: Photographic description of field sites
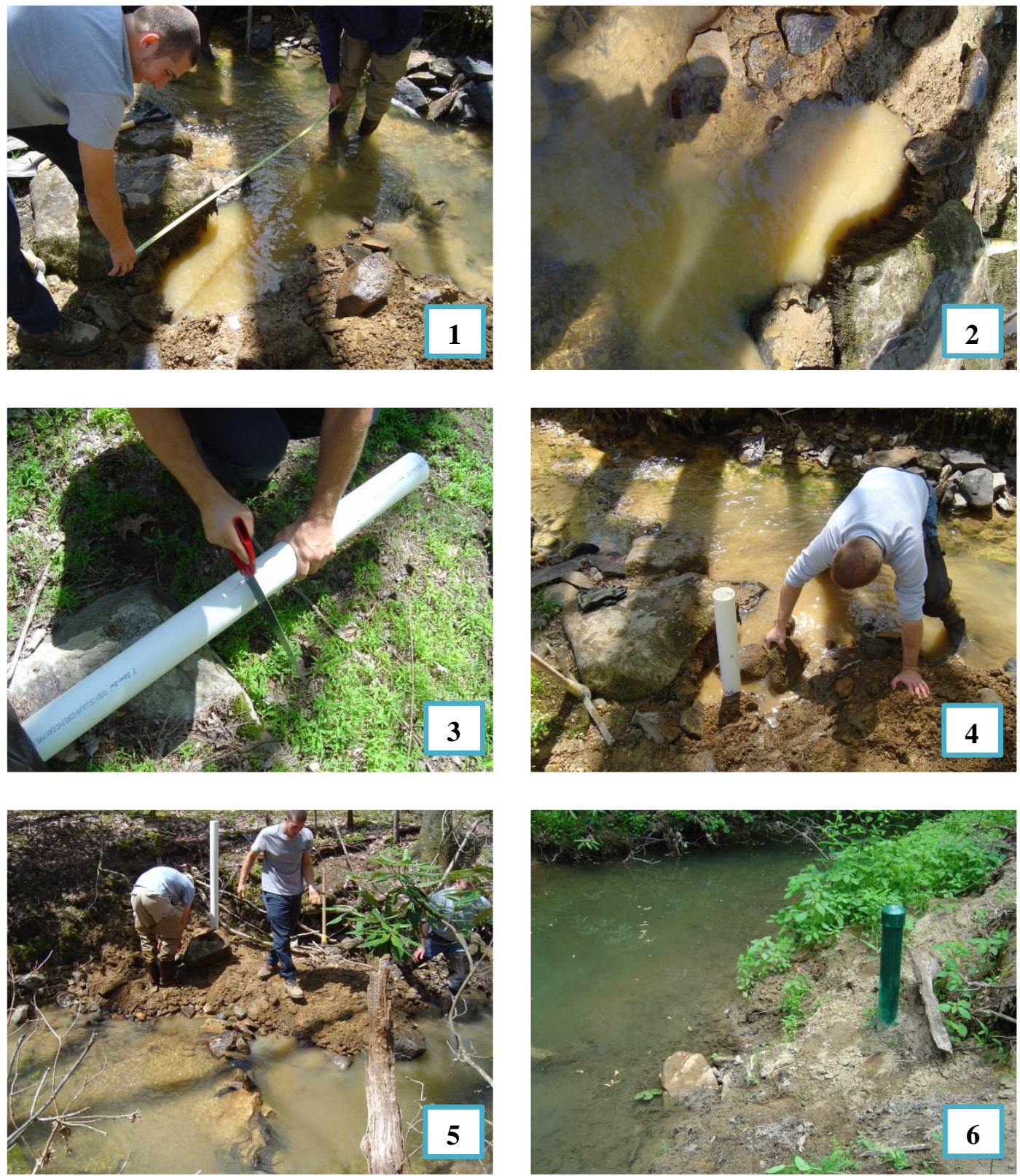

Figure 21. Installation of Levelogger housing. 1) Begun by digging a channel to the bottom of the stream bed. 2) Measured lengths: back of the excavation to the center of stream and from the bottom of excavtion vertically to an elevation above estimated storm water levels.

3) Cut the 3 inch PVC pipe to measured lengths and connected them together with a 90 degree elbow pipe. The pipe assembled is called the Levelogger "housing". 4) Placed pipe in excavated channel and placed large rocks around the housing. 5) Place and compact the excavated soil back into its original location around the housing. 6) Is the finished product of the Levelogger housing functioning with device installed. 

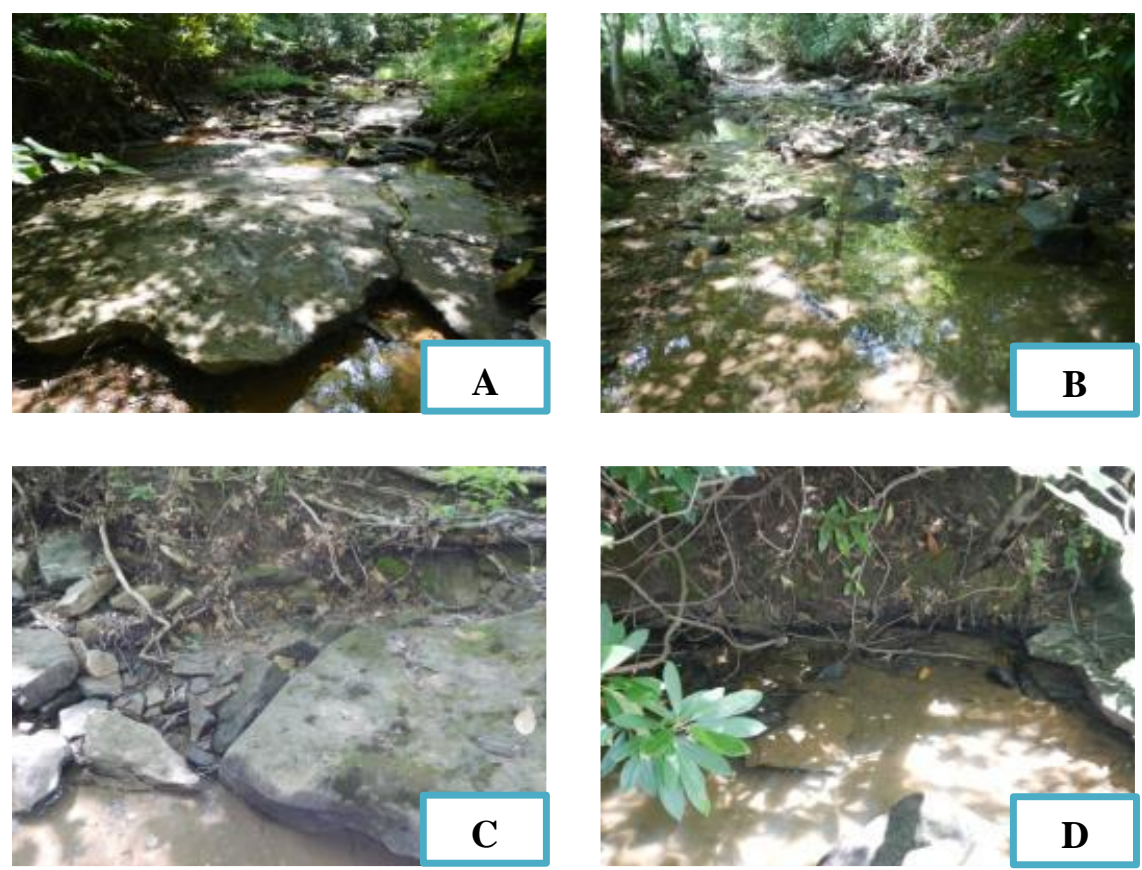

Figure 22. Photos of monitoring site of Lick Run North (Lck N). Pictures are referenced to stream flow direction: a) Upstream b) Downstream c) Left bank d) Right bank.
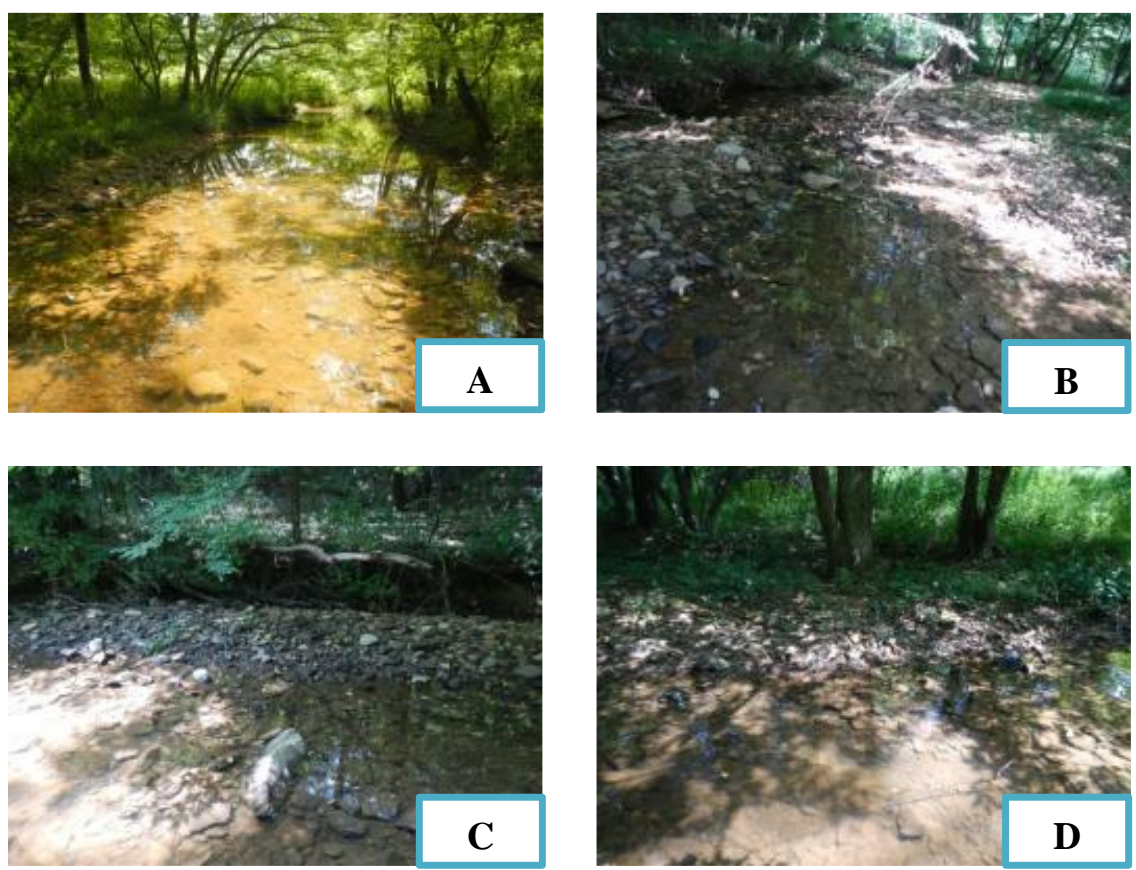

Figure 23. Photos of monitoring site South Lick Run (S Lck.. Pictures are referenced to stream flow direction: a) Upstream b) Downstream c) Left bank d) Right bank. 

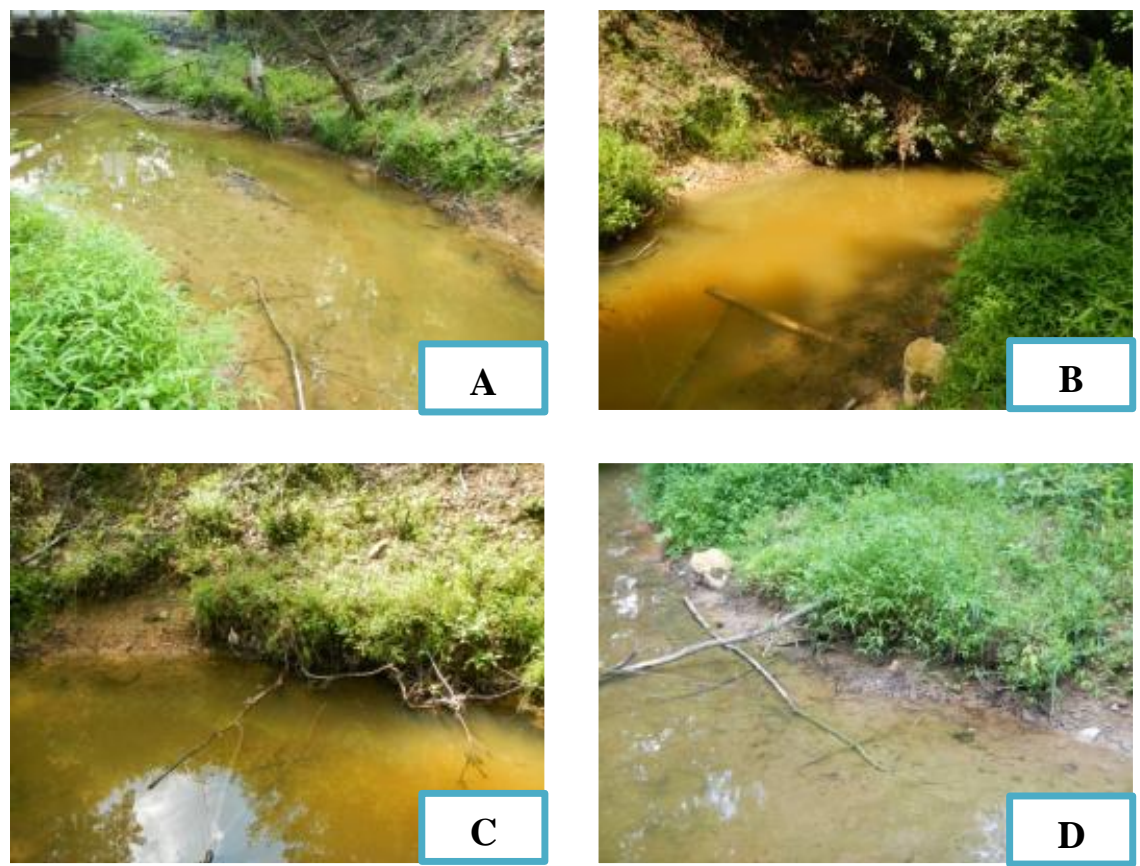

Figure 24. Photos of monitoring site Reservoir (Resv). Pictures are referenced to stream flow direction: a) Upstream b) Downstream c) Left bank d) Right bank.
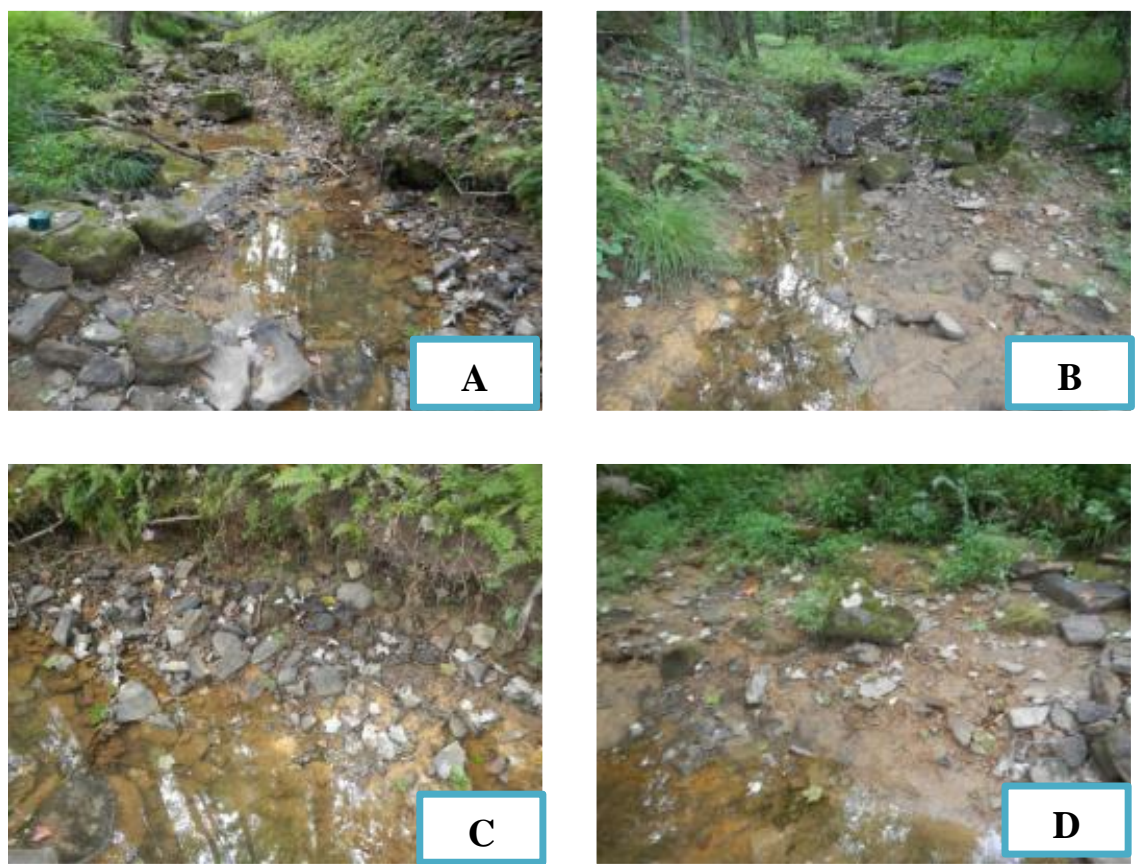

Figure 25. Photos of monitoring site Laurel Run Southeast (Lrn SE). Pictures are referenced to stream flow direction: a) Upstream b) Downstream c) Left bank d) Right bank. 

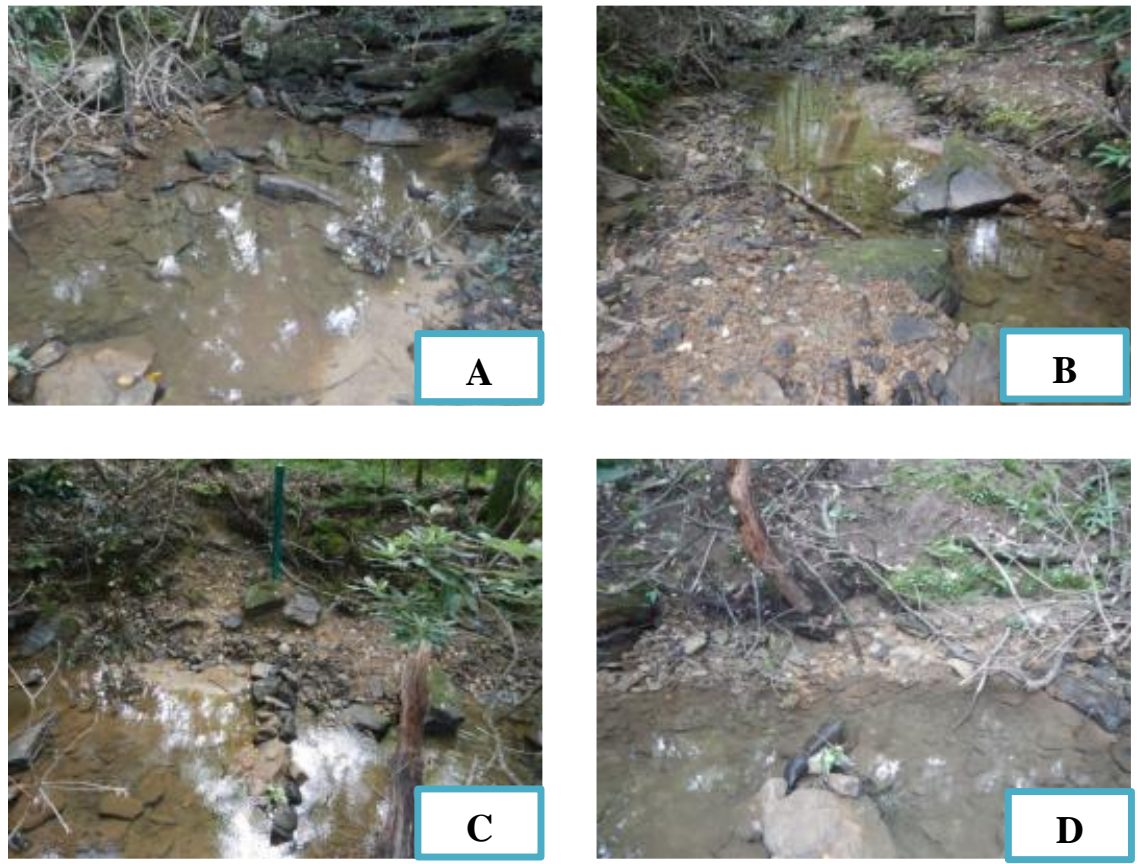

Figure 26. Photos of monitoring site South Laurel Run (S Lrn). Pictures are referenced to stream flow direction: a) Upstream b) Downstream c) Left bank d) Right bank.
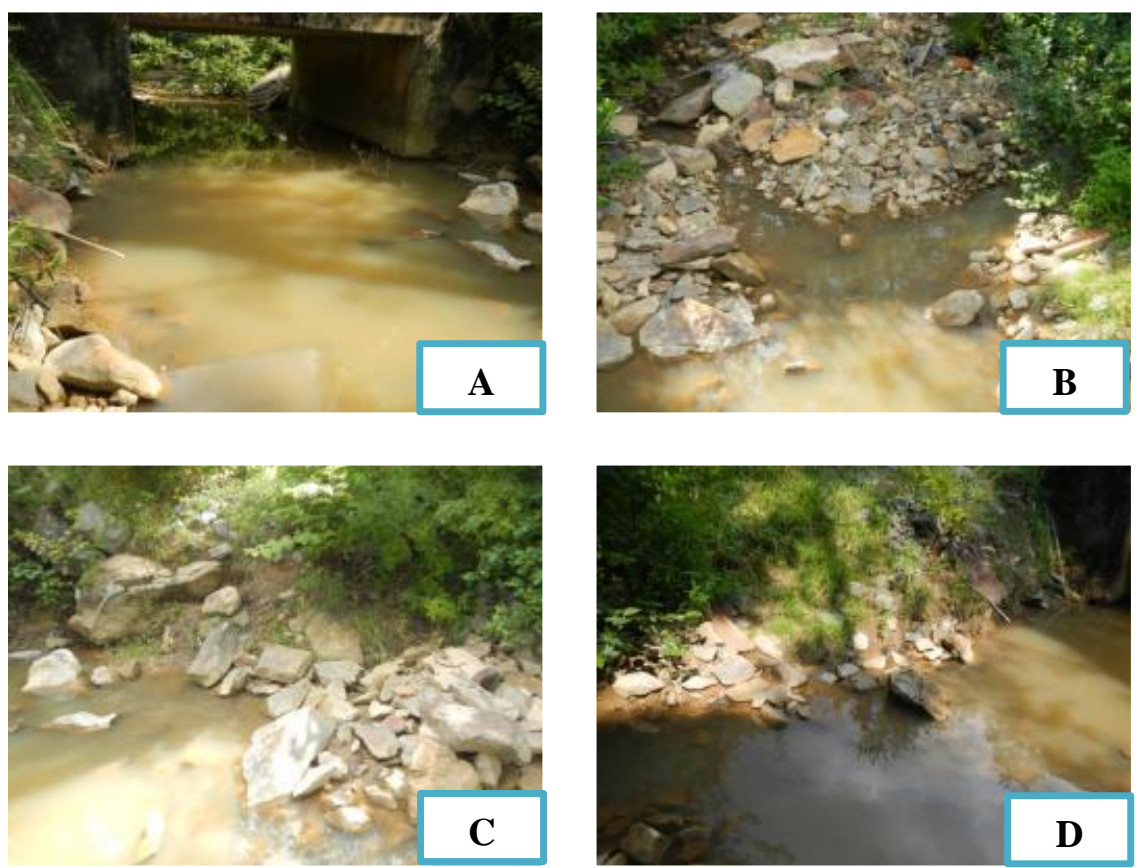

Figure 27. Photos of monitoring site Whiteday Creek Cherry Run Road (WD CHRY RD). Pictures are referenced to stream flow direction: a) Upstream b) Downstream c) Left bank d) Right bank. 

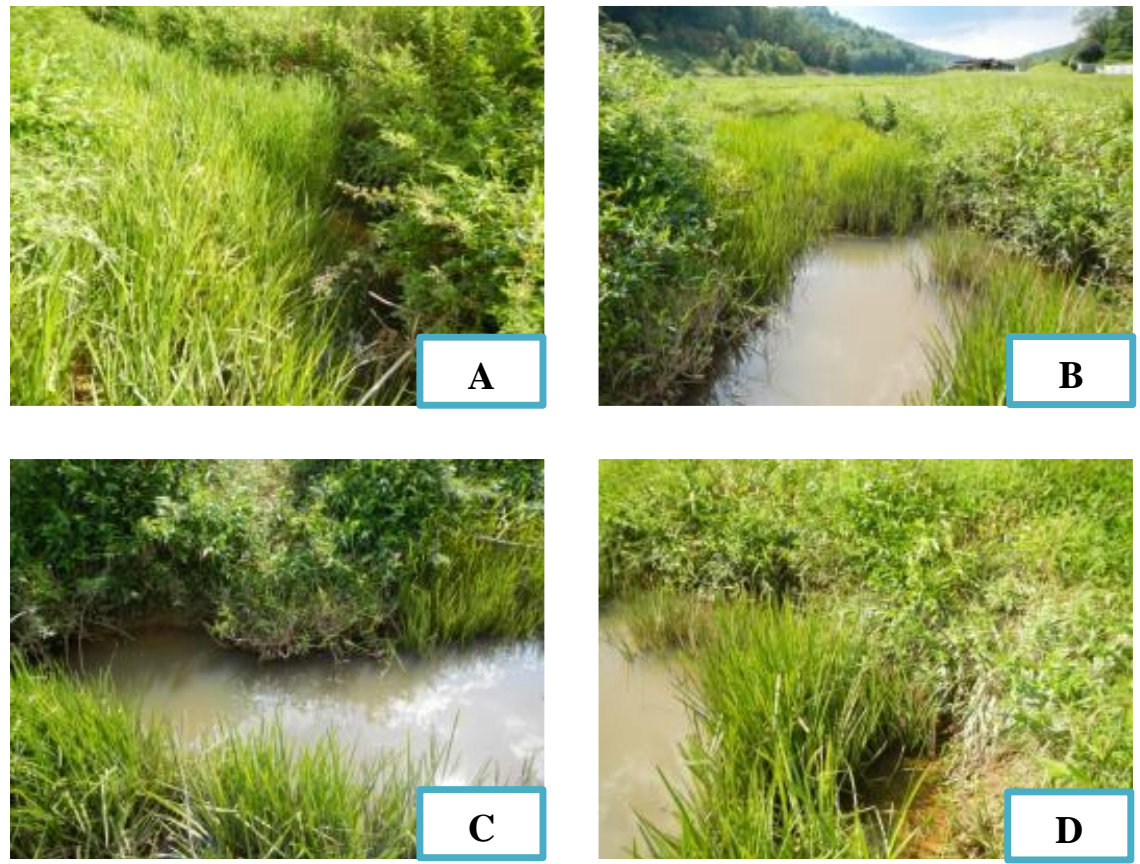

Figure 28. Photos of monitoring site South Whiteday Creek (WDS). Pictures are referenced to stream flow direction: a) Upstream b) Downstream c) Left bank d) Right bank.
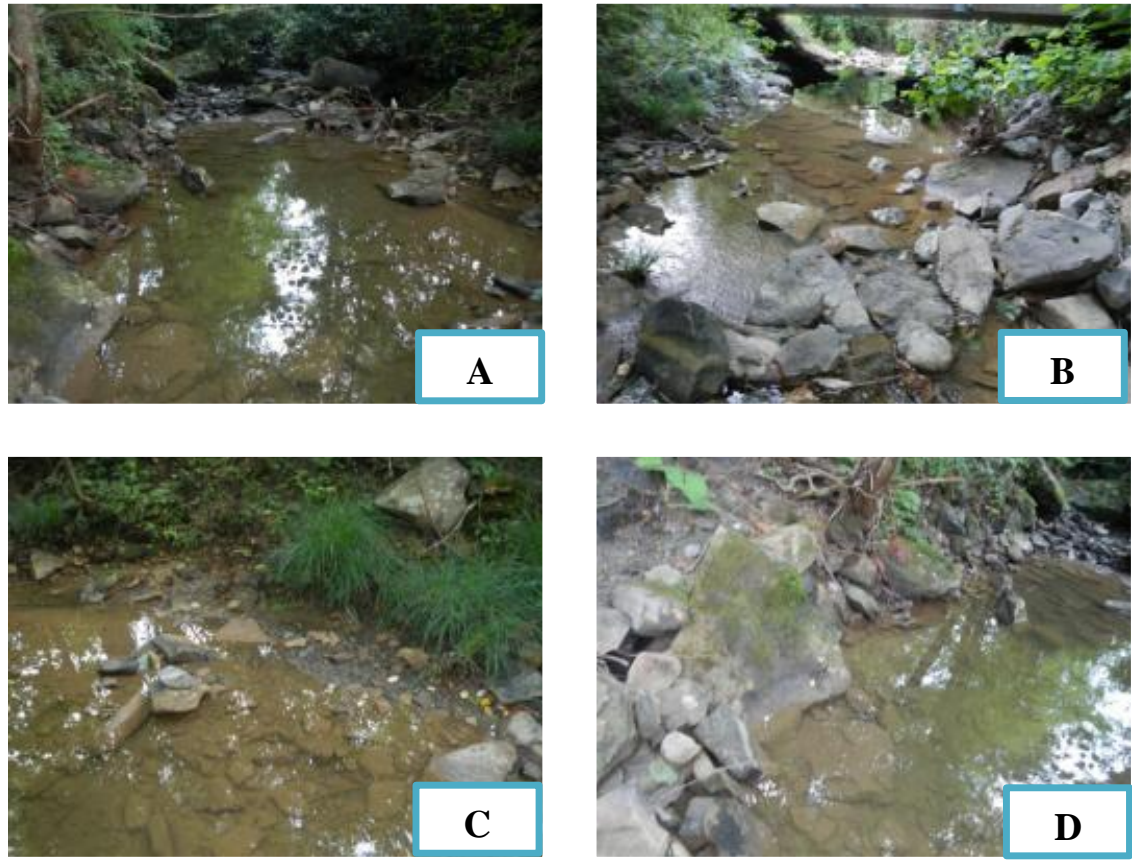

Figure 29. Photos of monitoring site Downstream Reservoir (Ds Res). Pictures are referenced to stream flow direction: a) Upstream b) Downstream c) Left bank d) Right bank. 
Appendix B: Physical, chemical, and ecological data



Figure 30. Grain size distribution at Lick Run North (Lck N). Data from pebble count that was collected on 5/24/12.

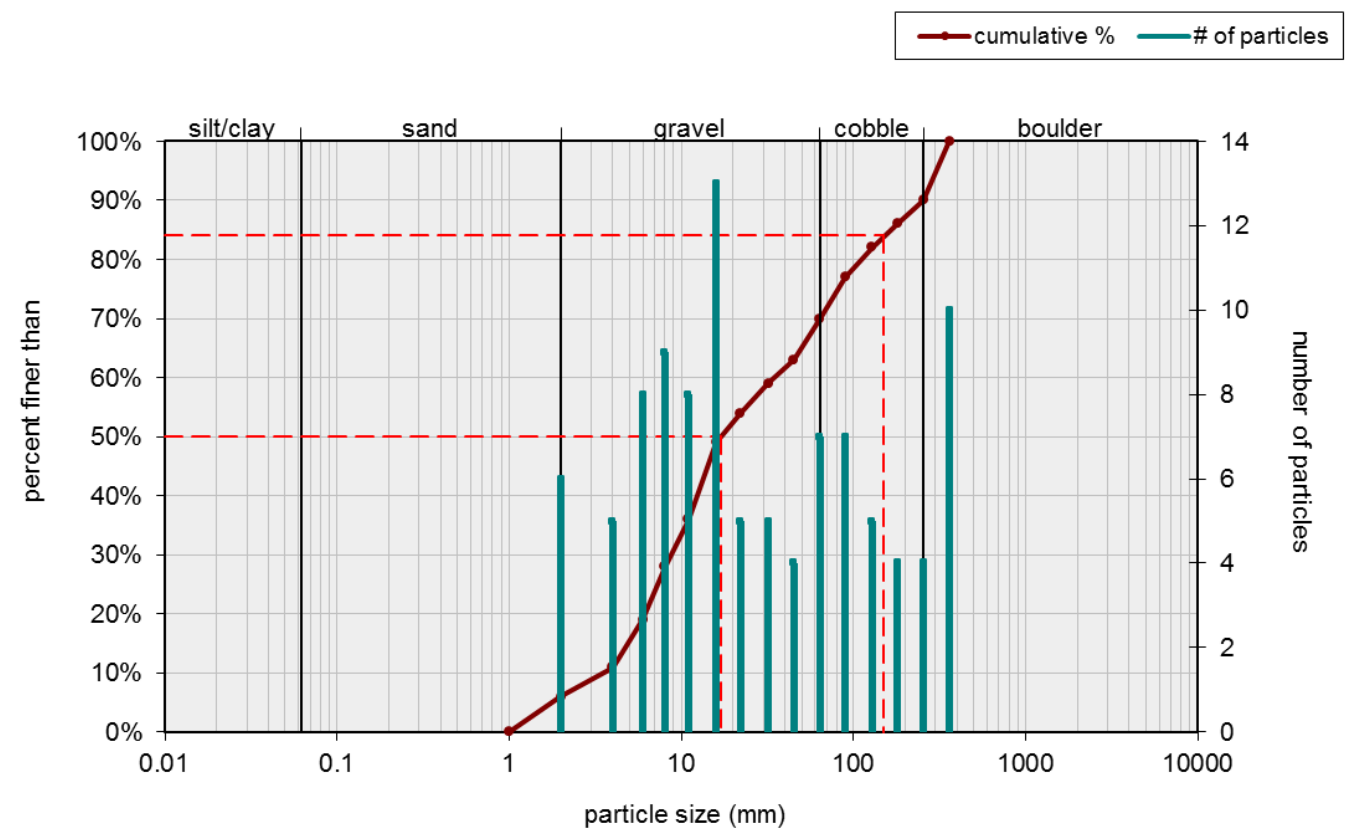

Figure 31. Grain size distribution at Lick Run North (Lck N). Data from pebble count that was collected on $7 / 3 / 12$. 


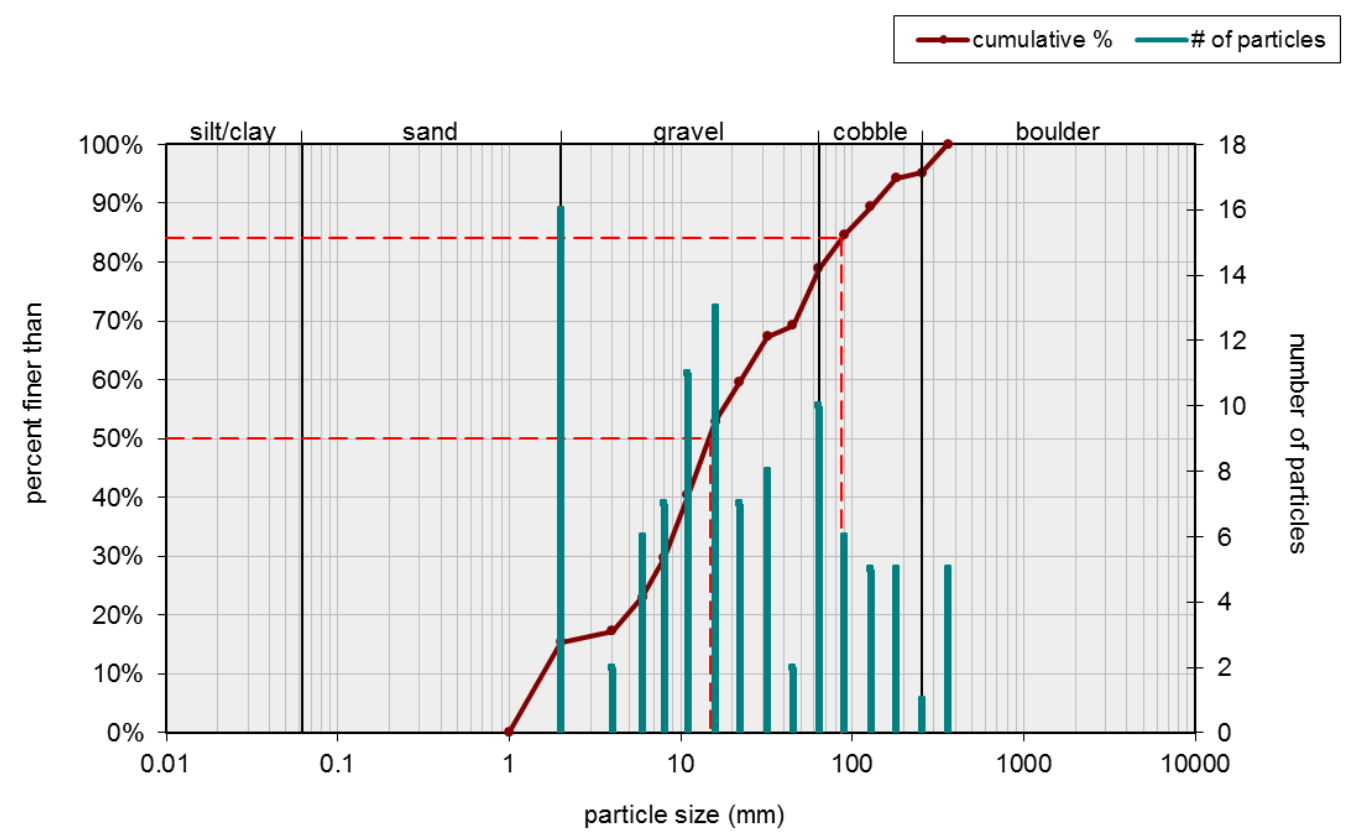

Figure 32. Grain size distribution at Lick Run North ( Lck N). Data from pebble count that was collected on $8 / 2 / 12$.

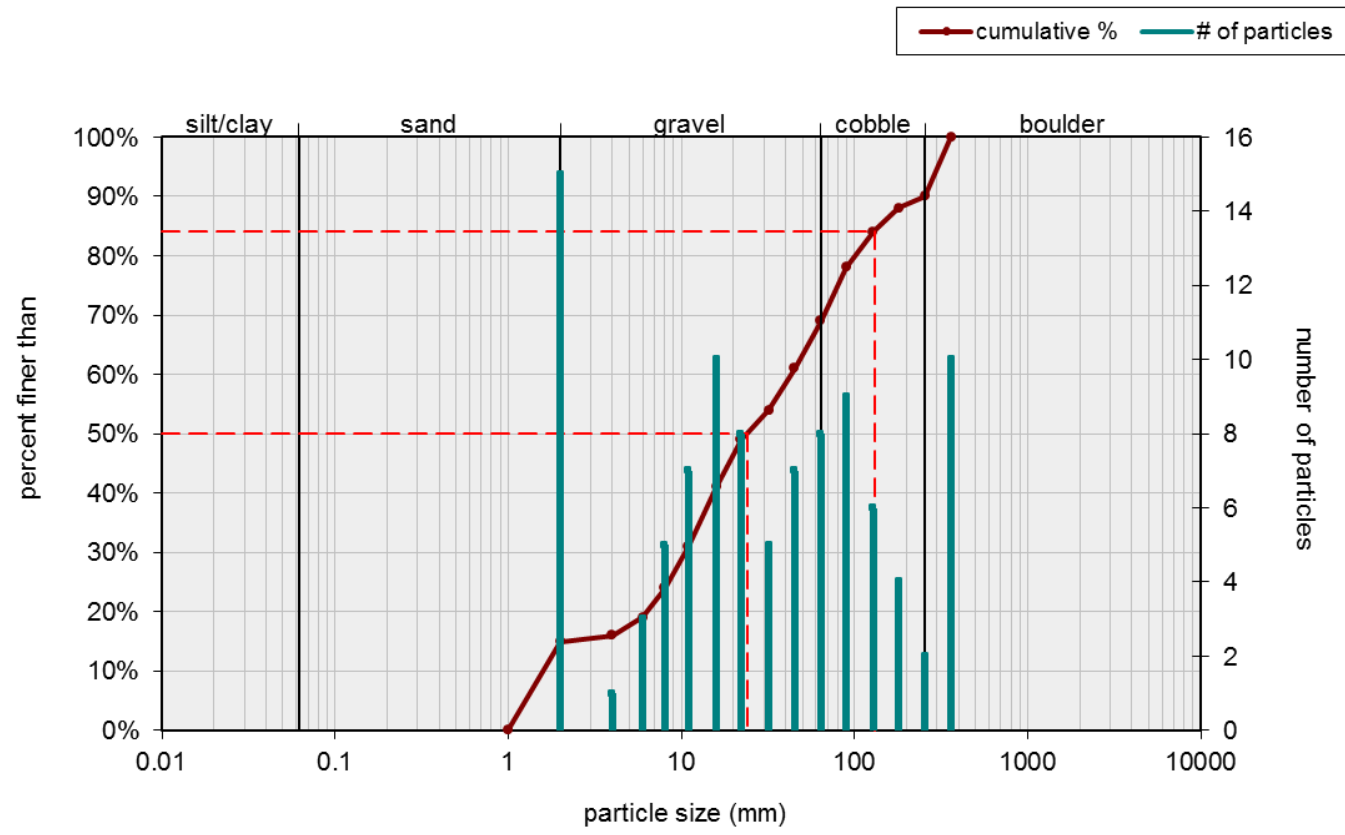

Figure 33. Grain size distribution at Lick Run North ( Lck N). Data from pebble count that was collected on $8 / 30 / 12$. 


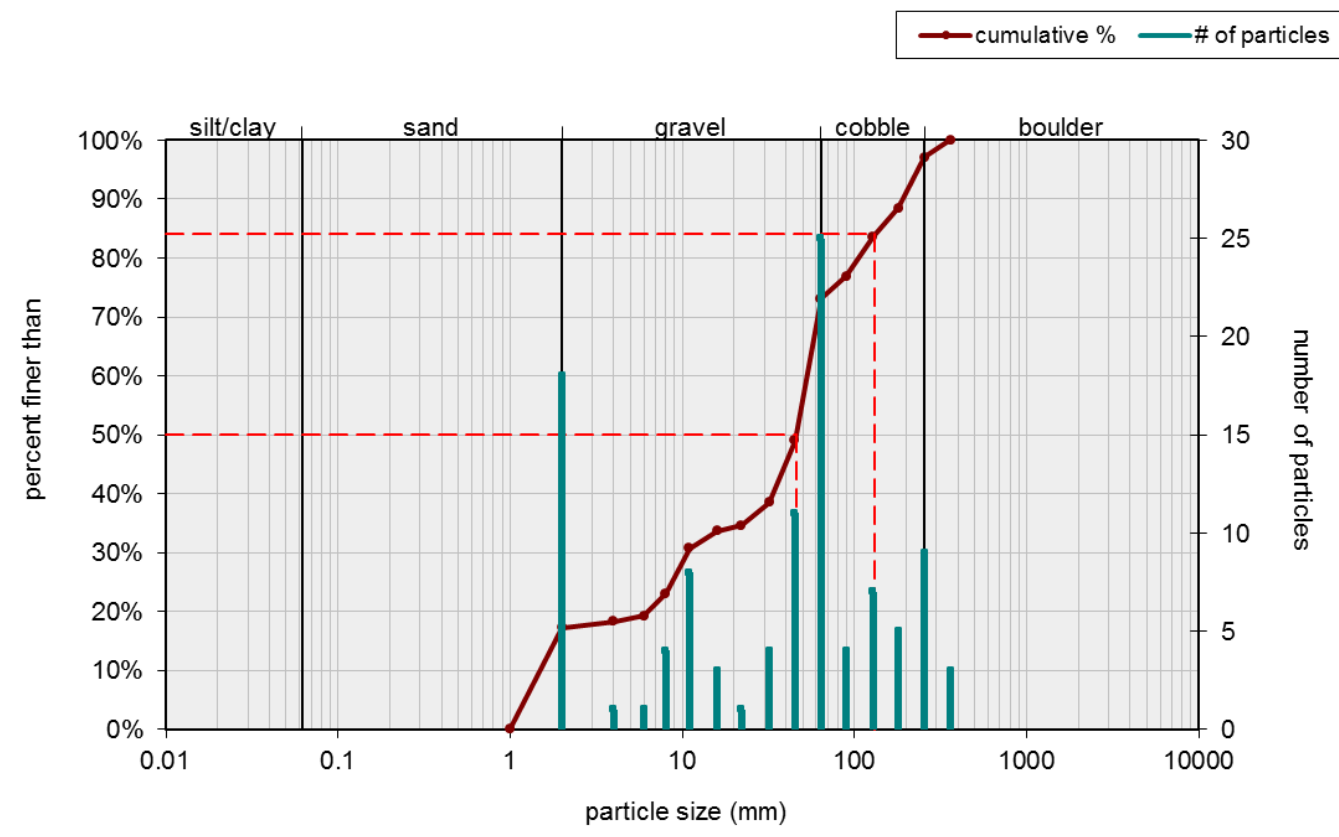

Figure 34. Grain size distribution at south Lick Run ( S Lck). Data from pebble count that was collected on $5 / 24 / 12$.

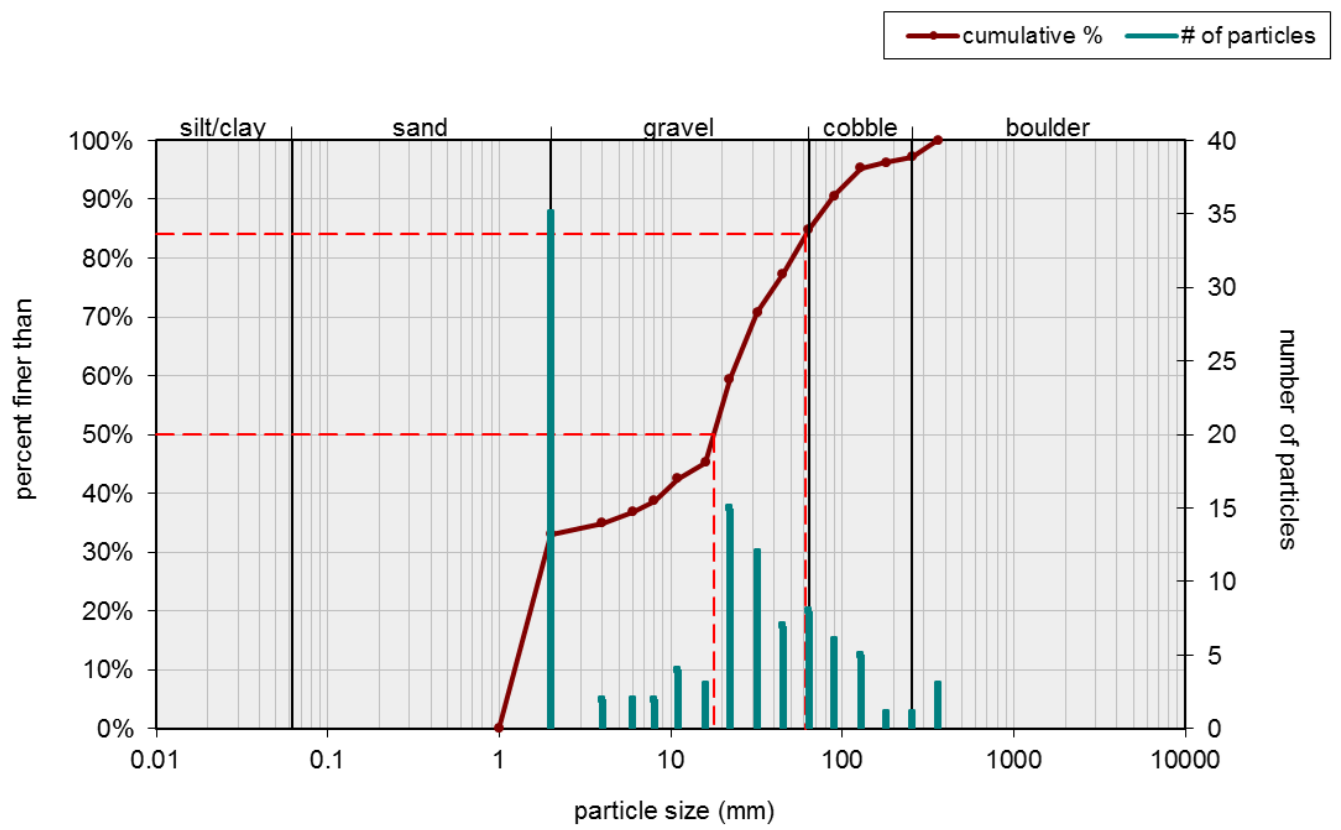

Figure 35. Grain size distribution at south Lick Run (S Lck). Data from pebble count that was collected on $7 / 3 / 12$. 


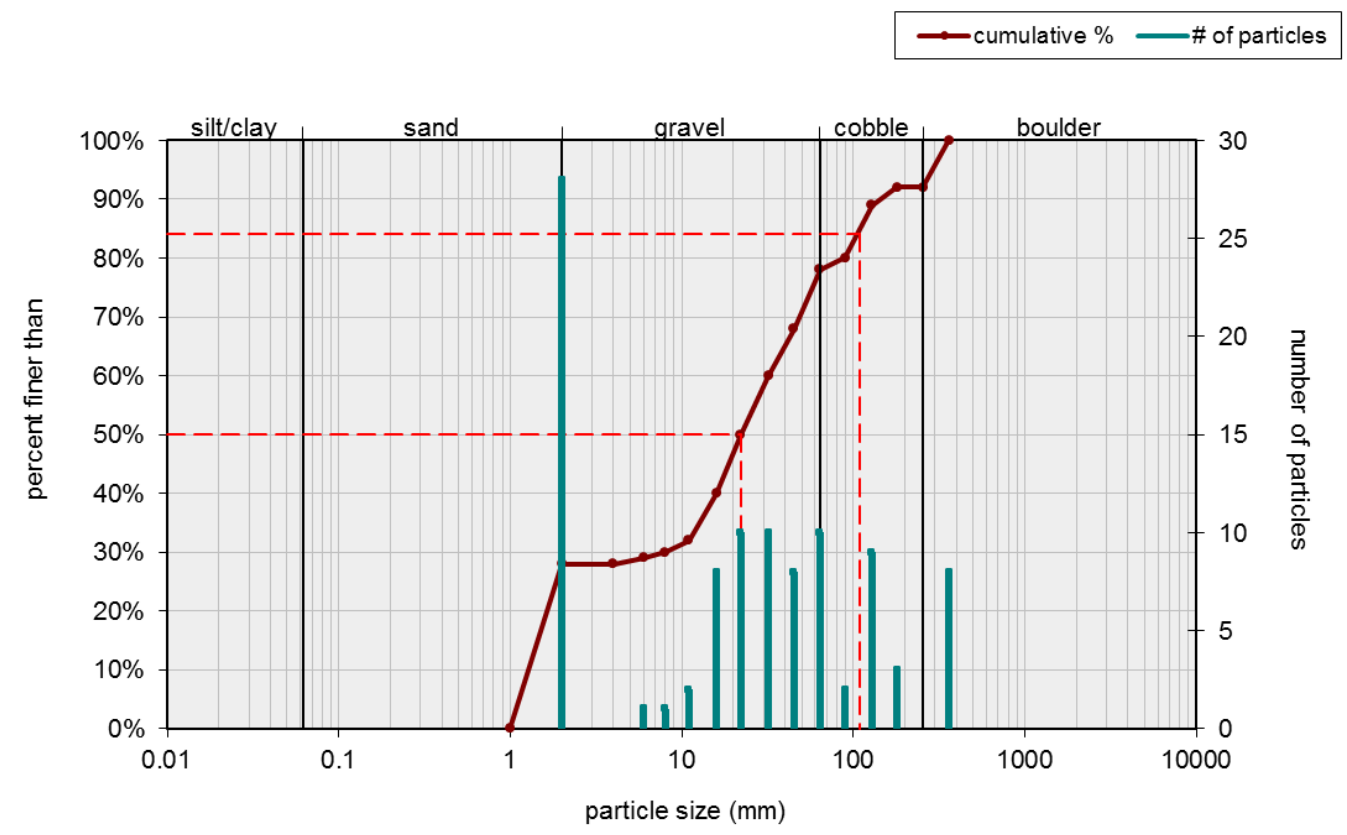

Figure 36. Grain size distribution at south Lick Run (S Lck). Data from pebble count that was collected on $8 / 2 / 12$.

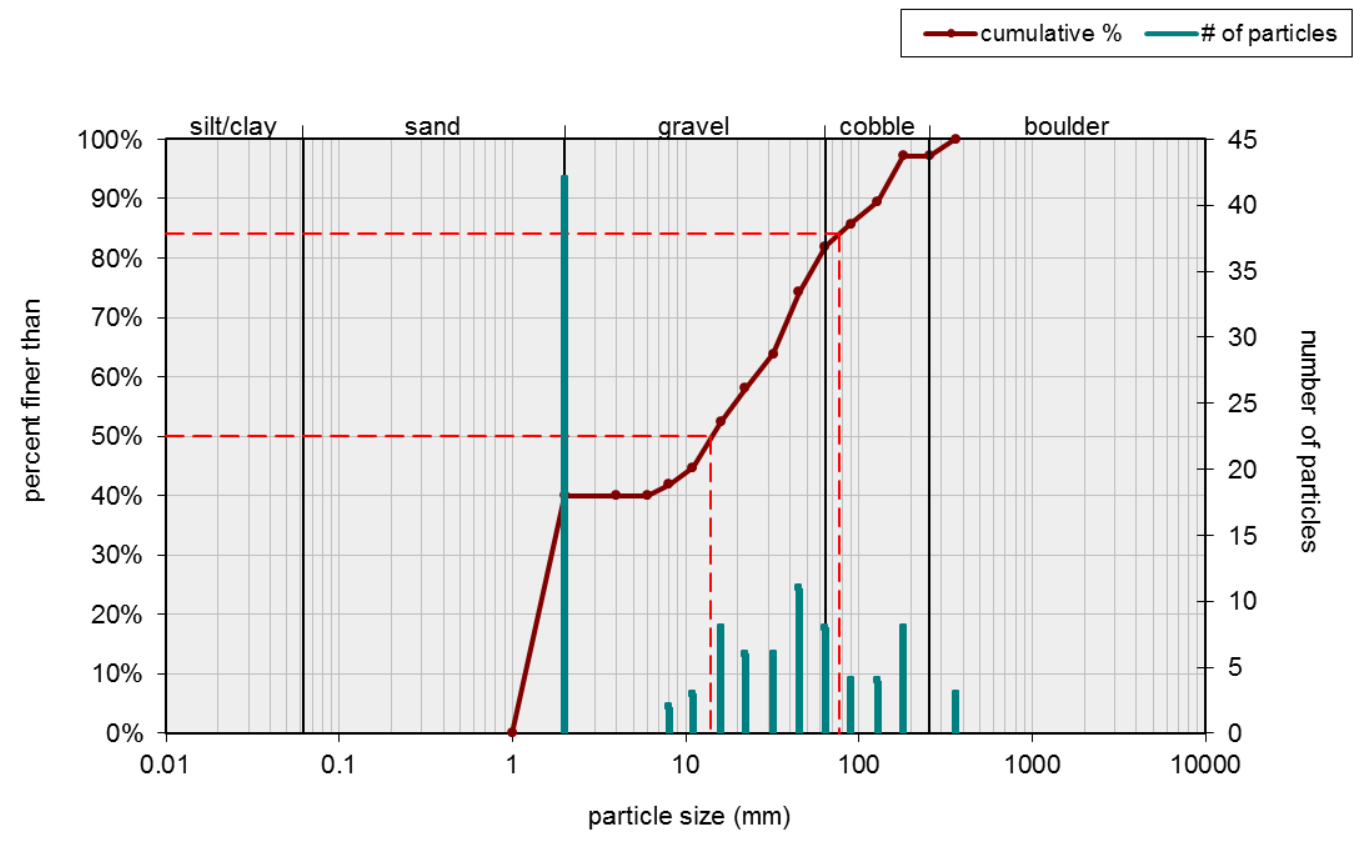

Figure 37. Grain size distribution at south Lick Run (S Lck). Data from pebble count that was collected on 8/30/12. 


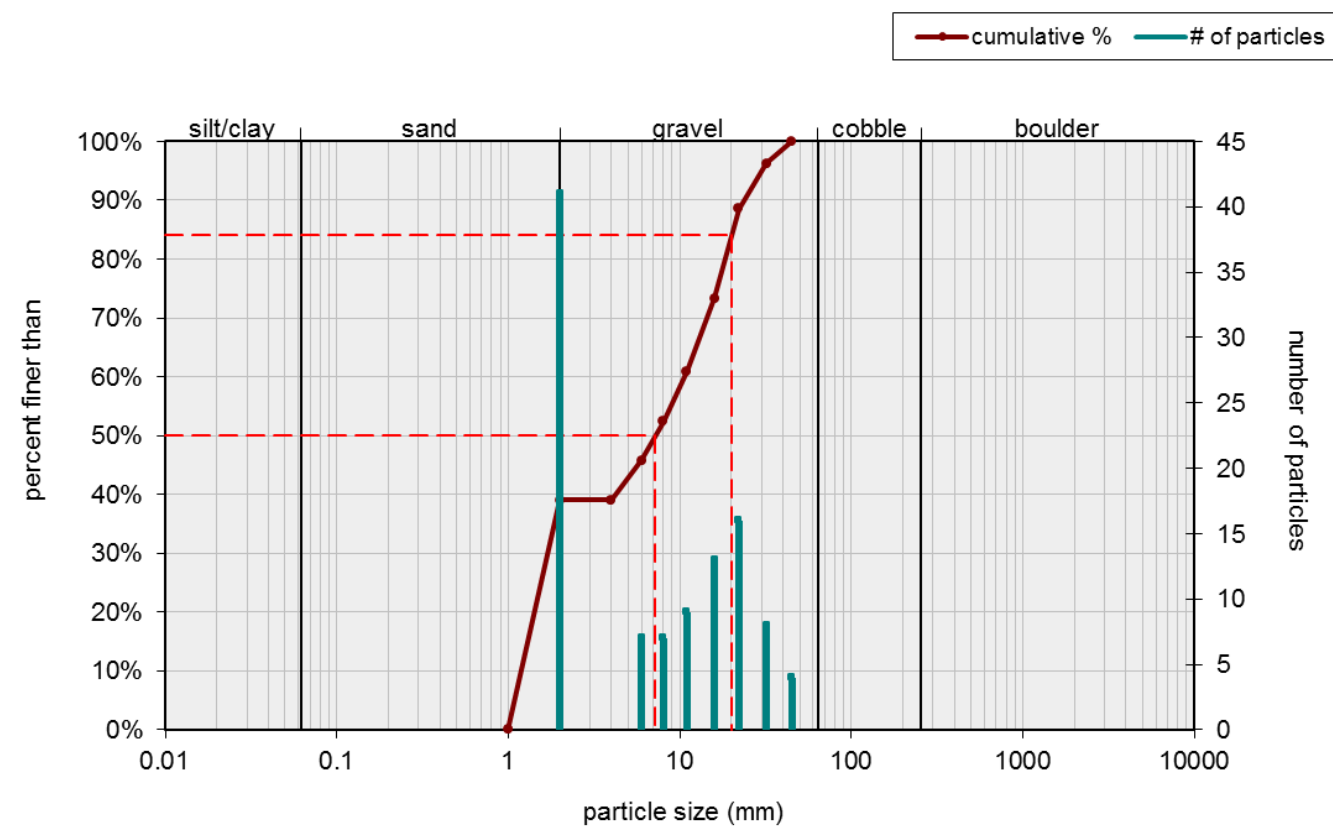

Figure 38. Grain size distribution at Reservoir (Resv). Data from pebble count that was collected on $5 / 24 / 12$.

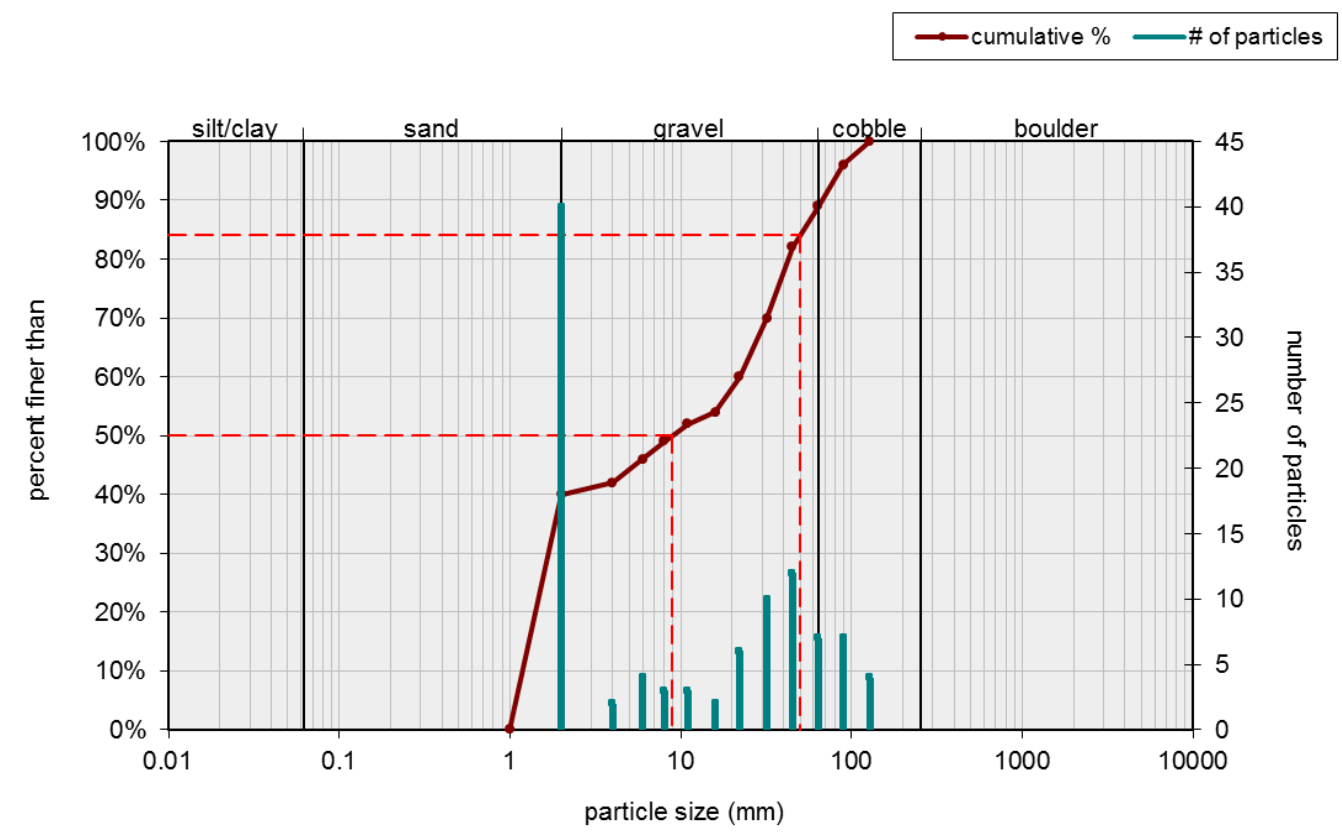

Figure 39. Grain size distribution at Reservoir (Resv). Data from pebble count that was collected on $7 / 3 / 12$. 




Figure 40. Grain size distribution at Reservoir (Resv). Data from pebble count that was collected on $8 / 2 / 12$.

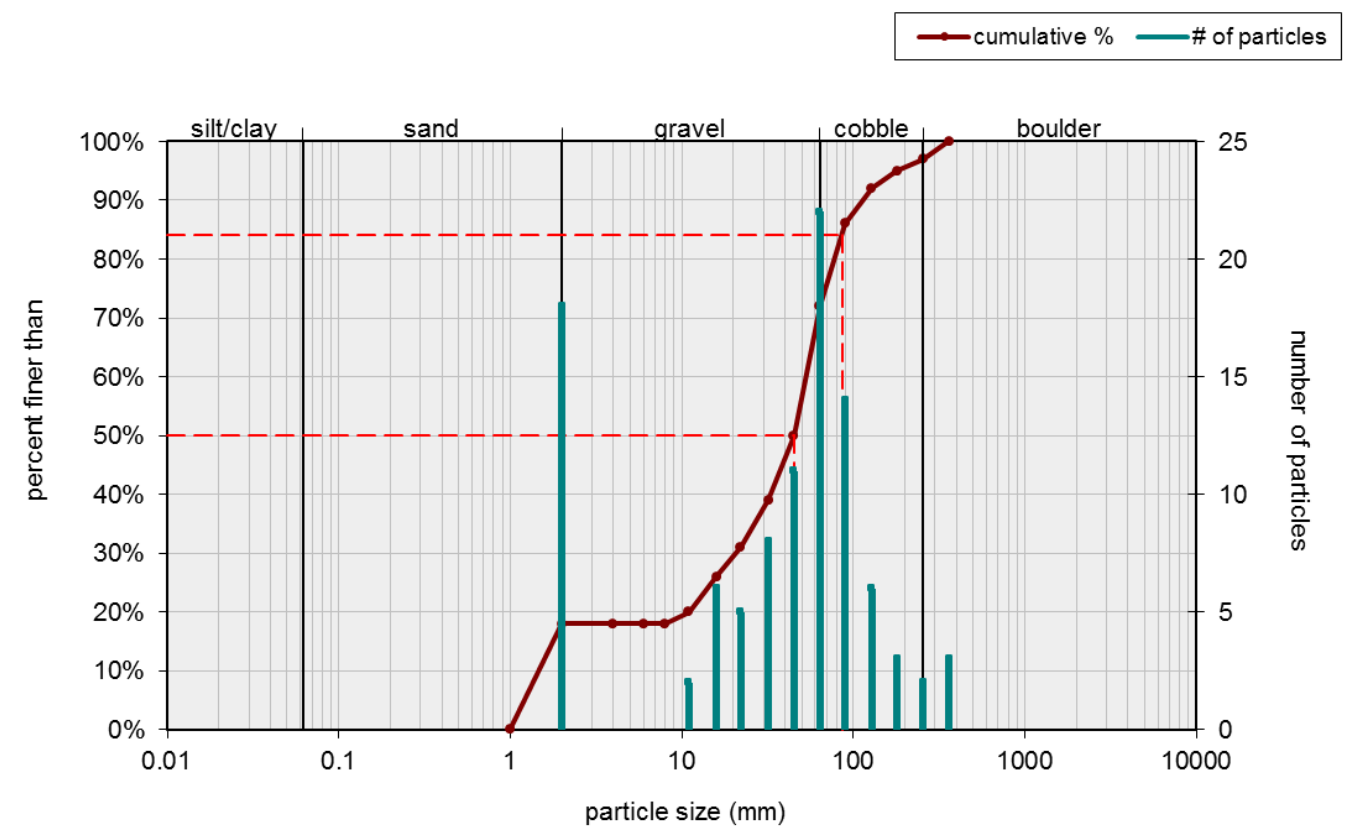

Figure 41. Grain size distribution at Laurel Run Southeast (Lrn SE). Data from pebble count that was collected on $5 / 24 / 12$. 




Figure 42. Grain size distribution at Laurel Run Southeast (Lrn SE). Data from pebble count that was collected on $7 / 3 / 12$.

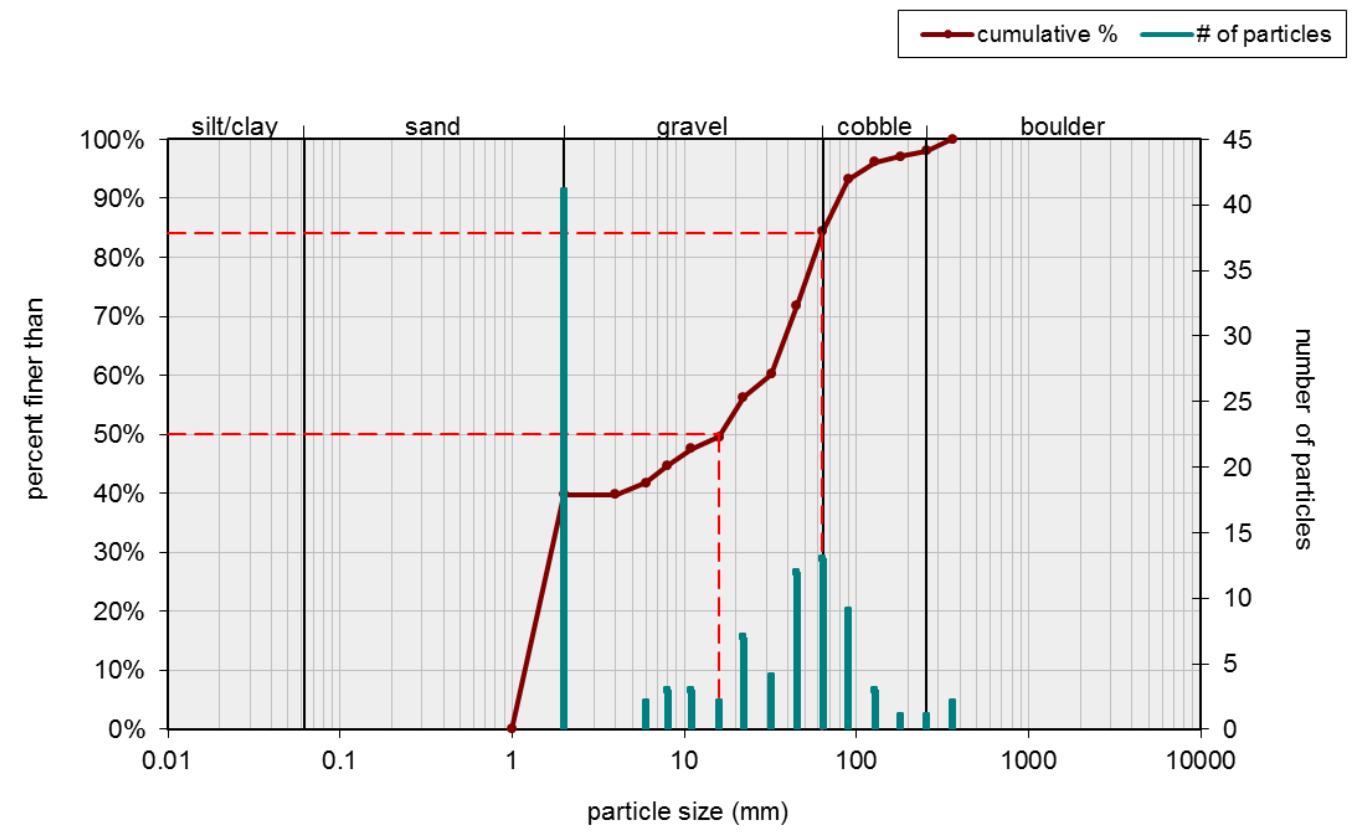

Figure 43. Grain size distribution at Laurel Run Southeast (Lrn SE). Data from pebble count that was collected on $8 / 2 / 12$. 


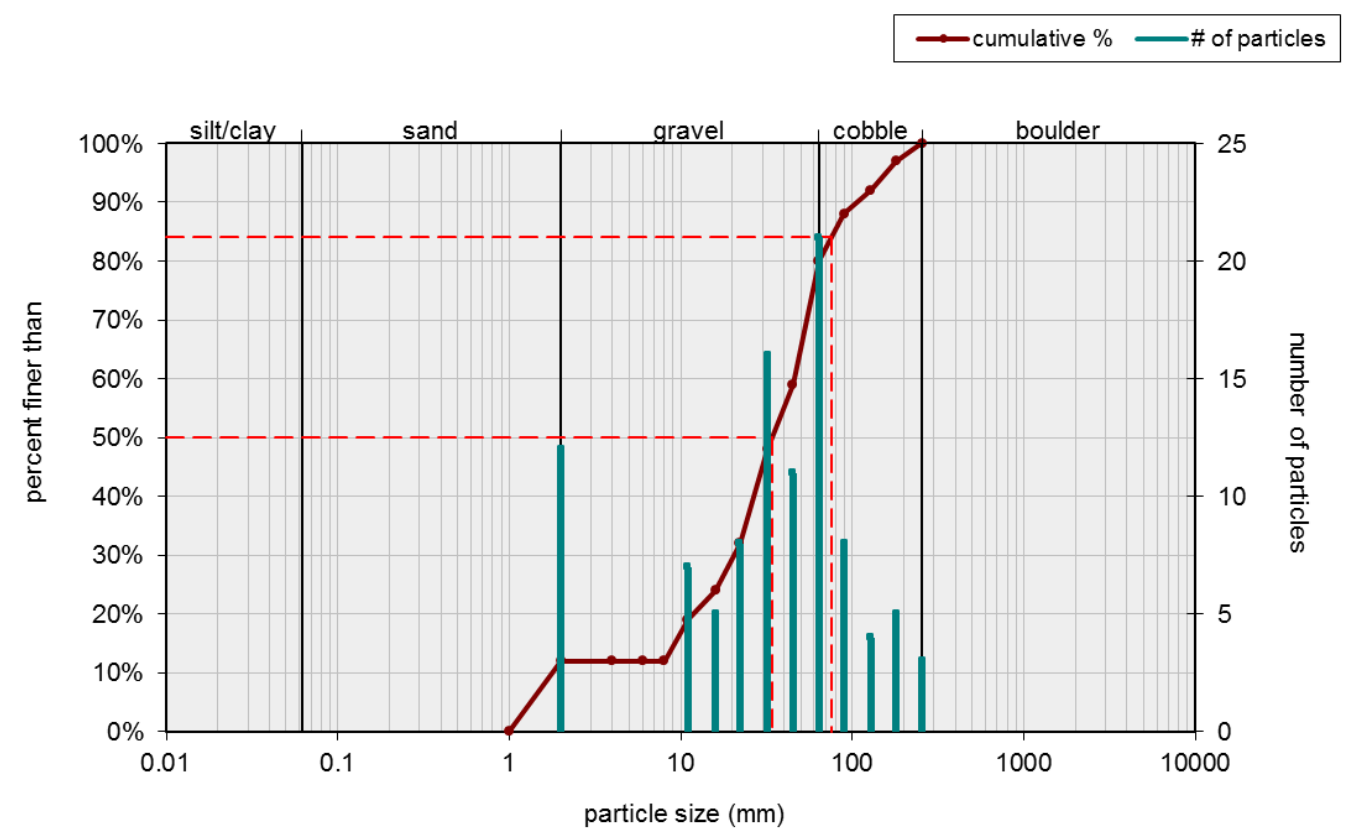

Figure 44. Grain size distribution at south Laurel Run (S Lrn). Data from pebble count that was collected on $5 / 24 / 12$.

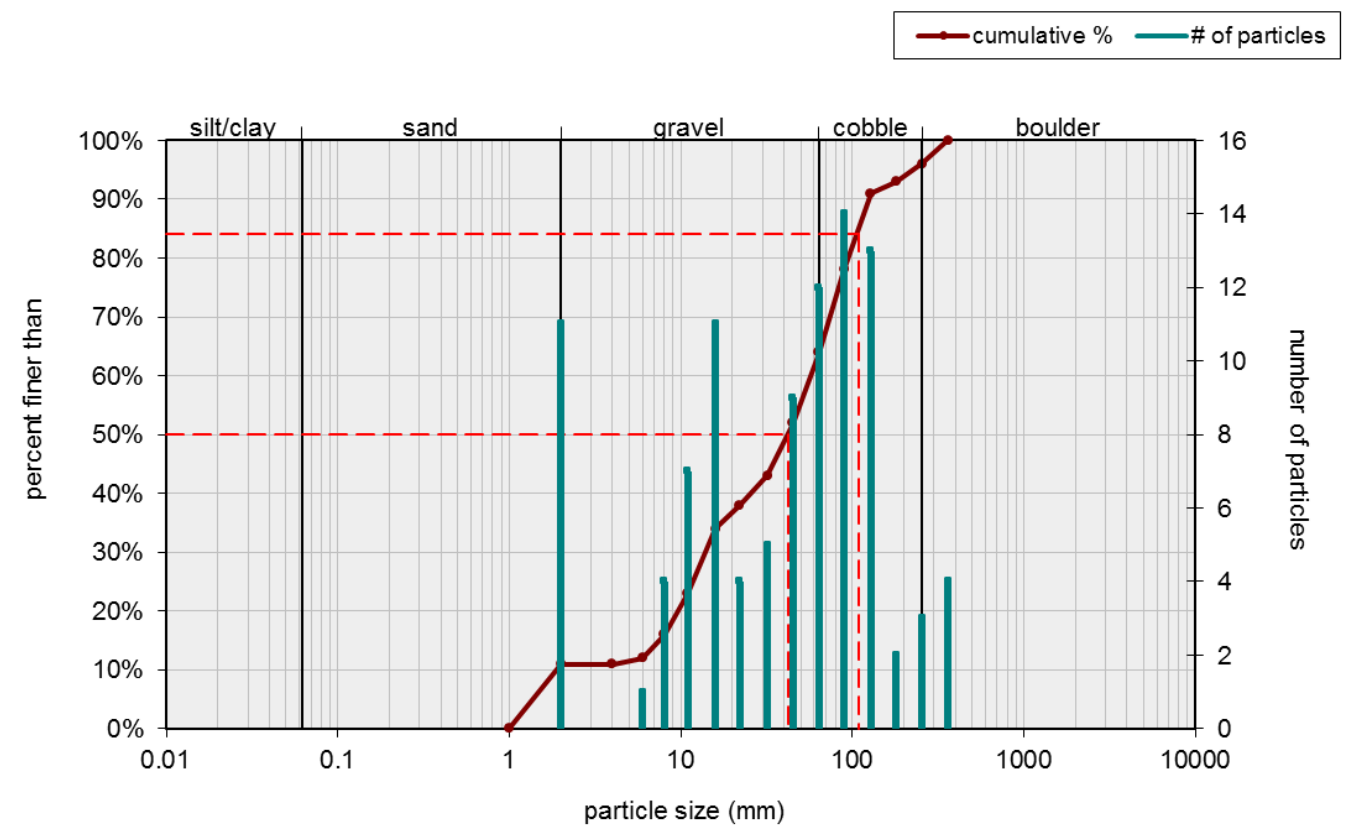

Figure 45. Grain size distribution at south Laurel Run (S Lrn). Data from pebble count that was collected on $7 / 3 / 12$. 


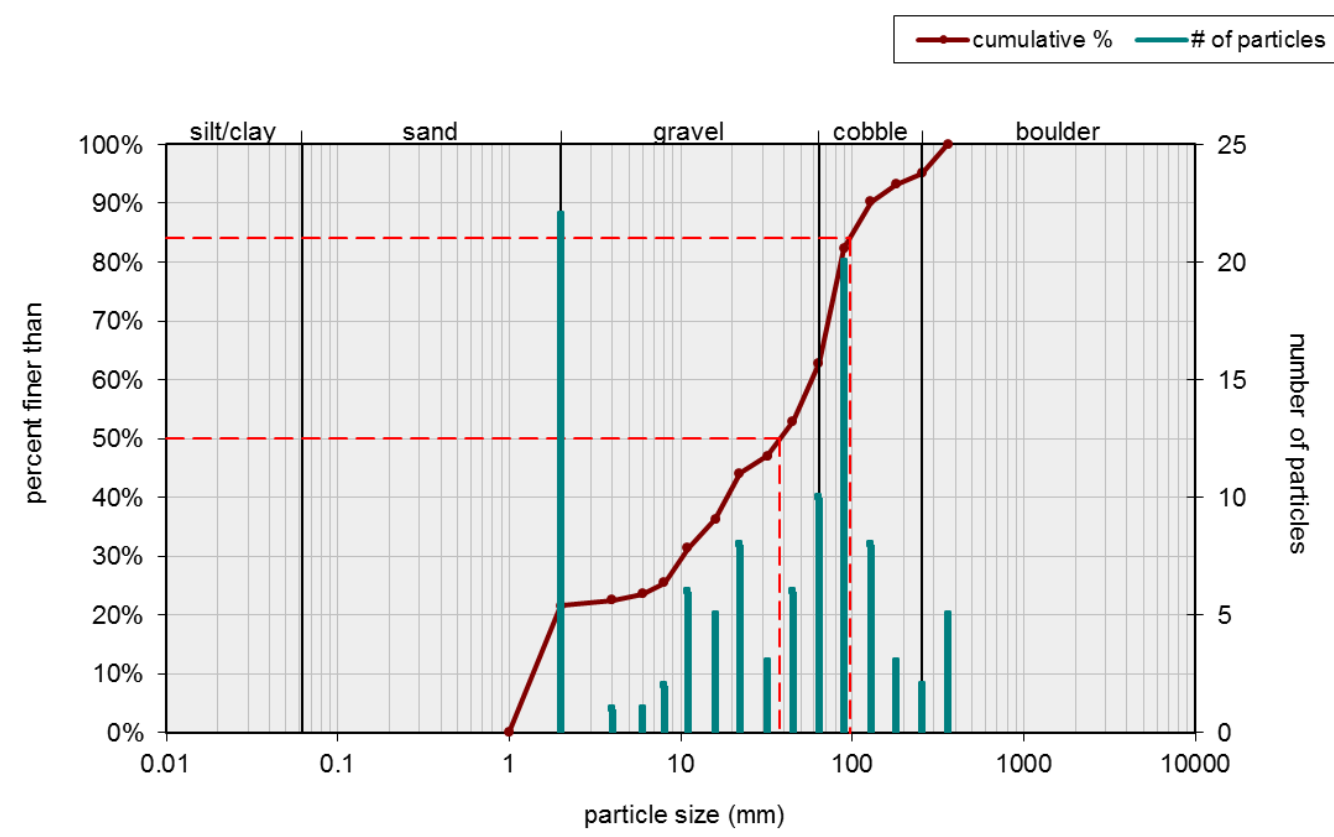

Figure 46. Grain size distribution at south Laurel Run (S Lrn). Data from pebble count that was collected on $8 / 2 / 12$.

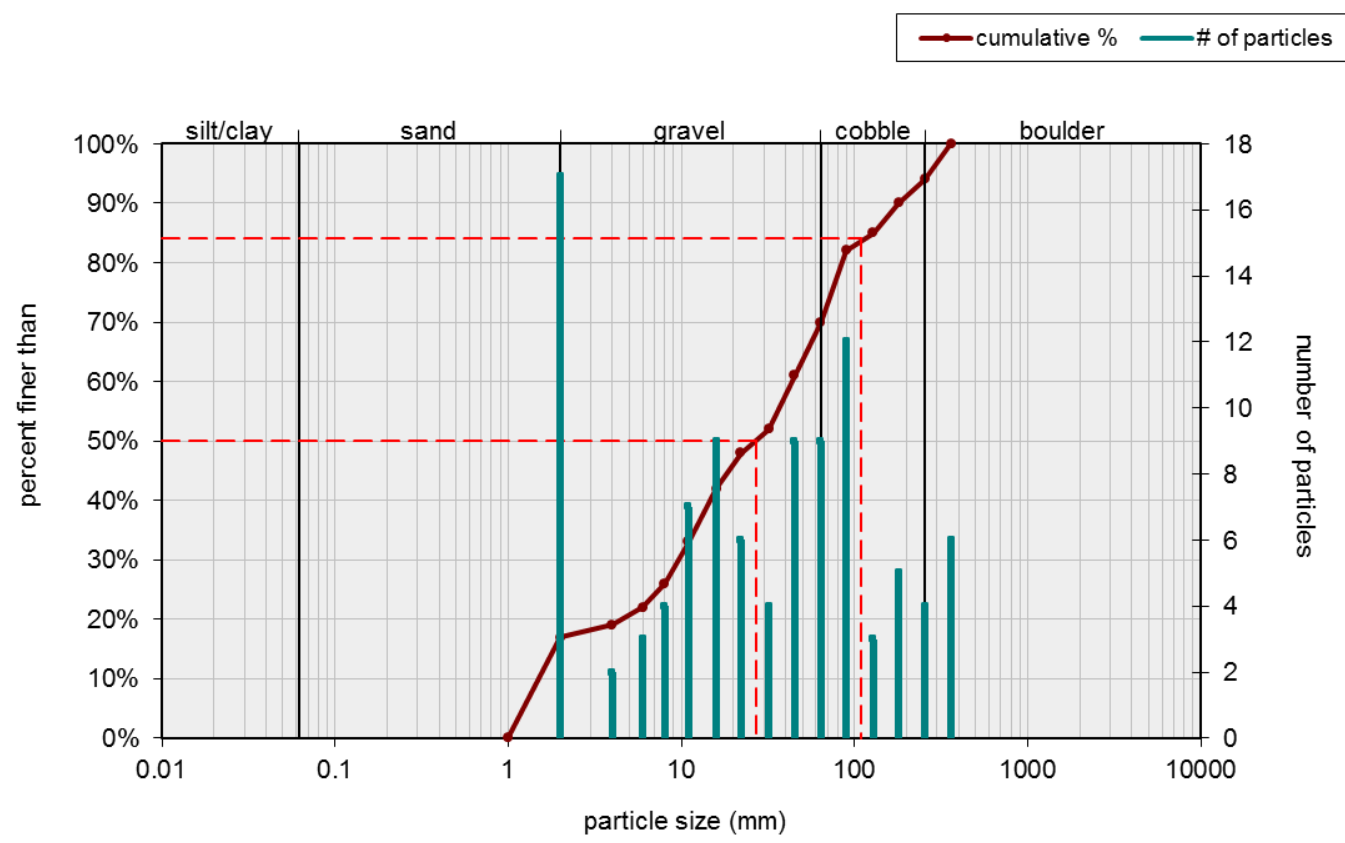

Figure 47. Grain size distribution at south Laurel Run (S Lrn). Data from pebble count that was collected on $8 / 30 / 12$. 


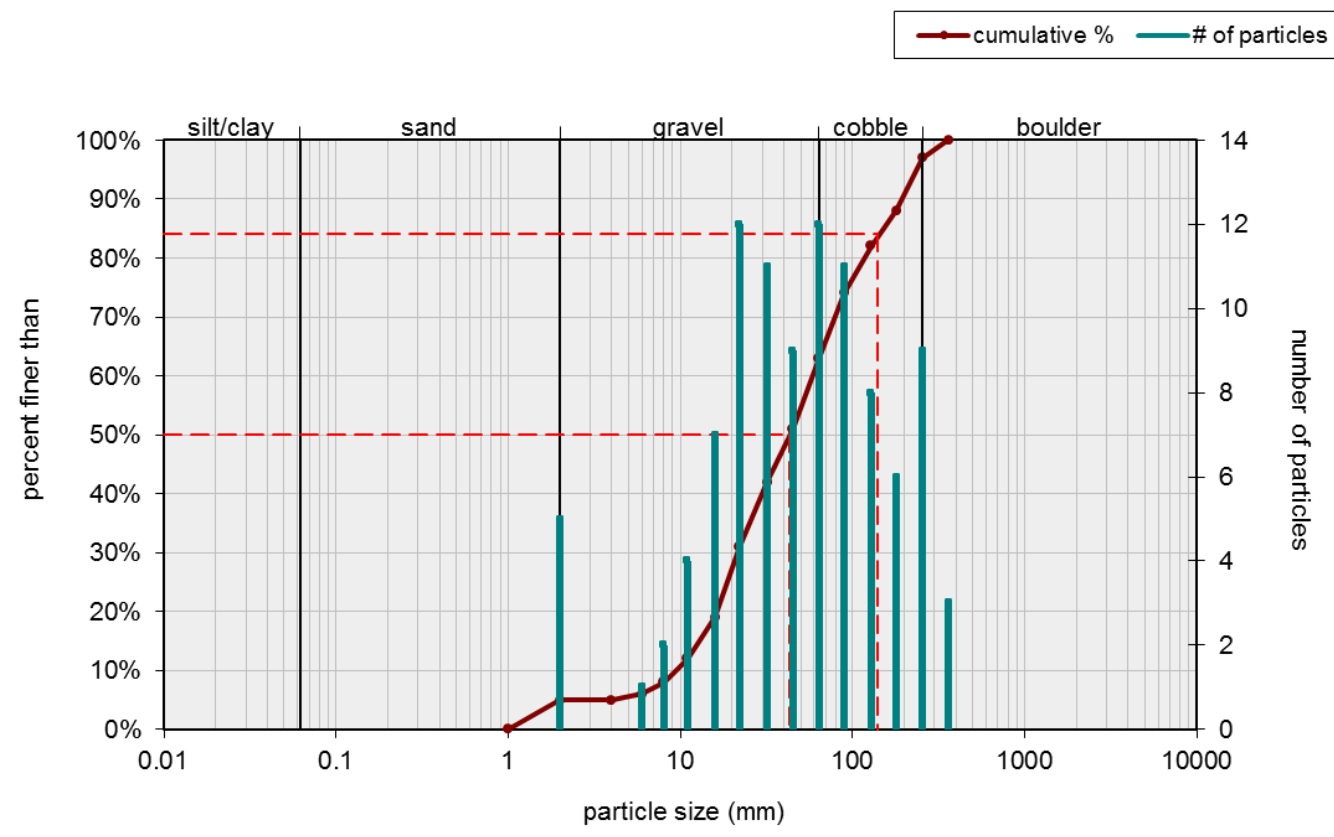

Figure 48. Grain size distribution at Whiteday Cherry Run Road (WD CHRY RD). Data from pebble count that was collected on 5/24/12.

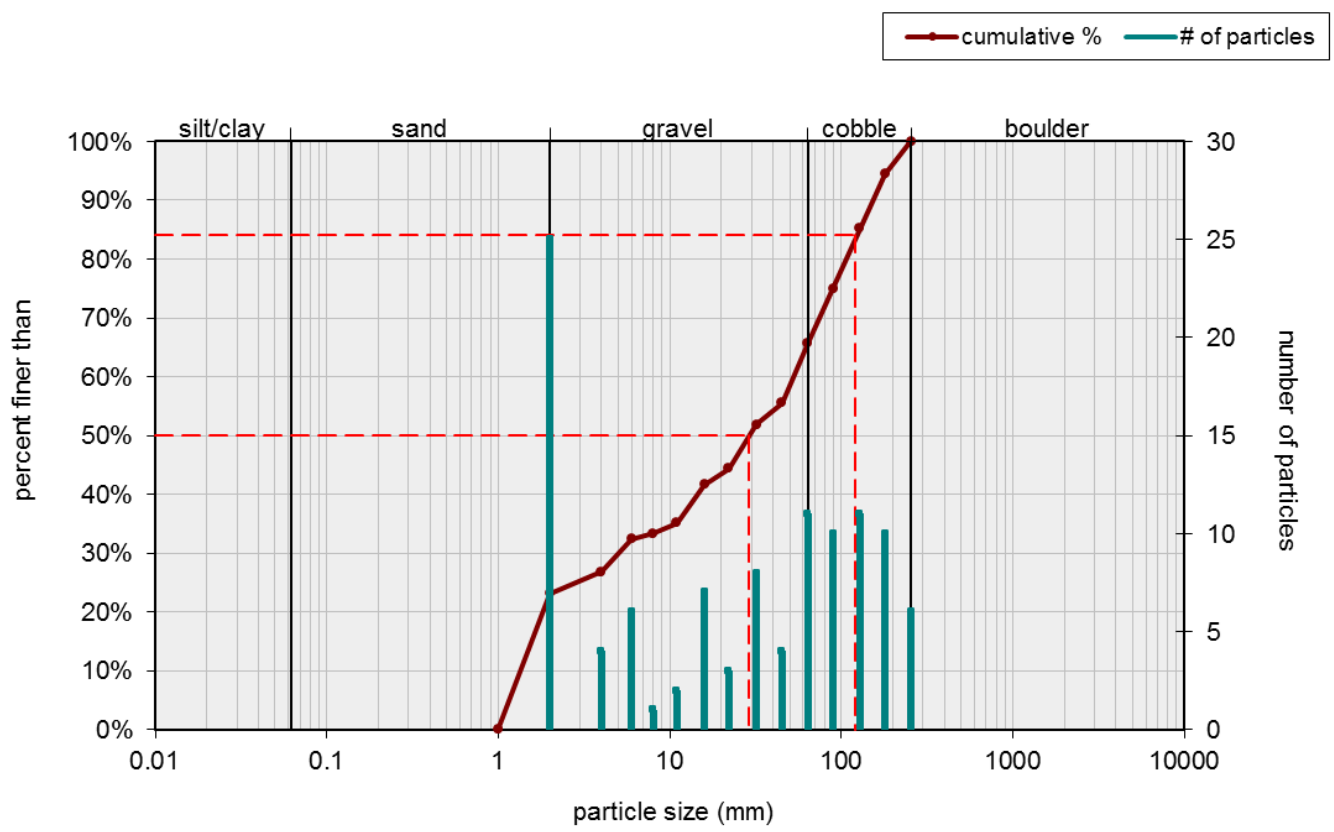

Figure 49. Grain size distribution at Whiteday Cherry Run Road (WD CHRY RD). Data from pebble count that was collected on 7/3/12. 


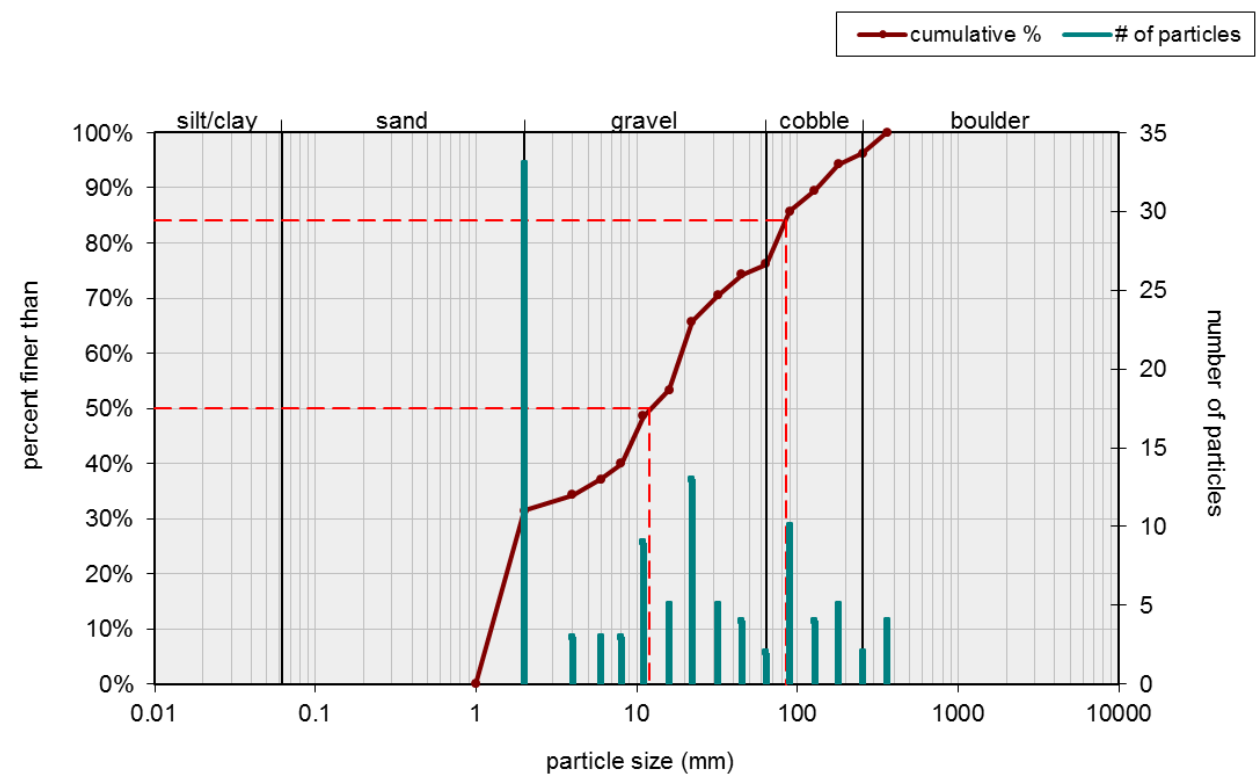

Figure 50. Grain size distribution at Whiteday Cherry Run Road (WD CHRY RD). Data from pebble count that was collected on $8 / 2 / 12$.

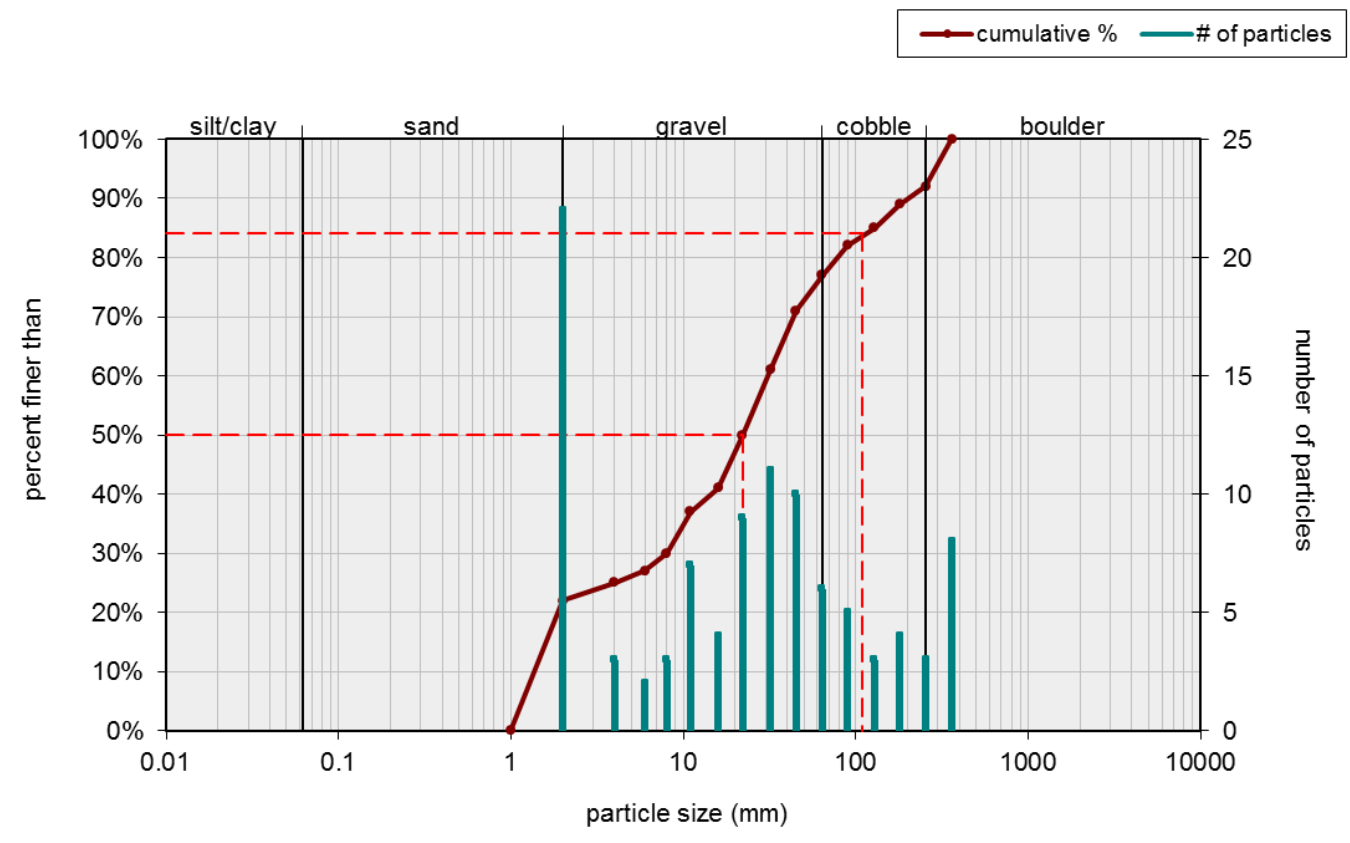

Figure 51. Grain size distribution at Whiteday Cherry Run Road (WD CHRY RD). Data from pebble count that was collected on $8 / 30 / 12$. 


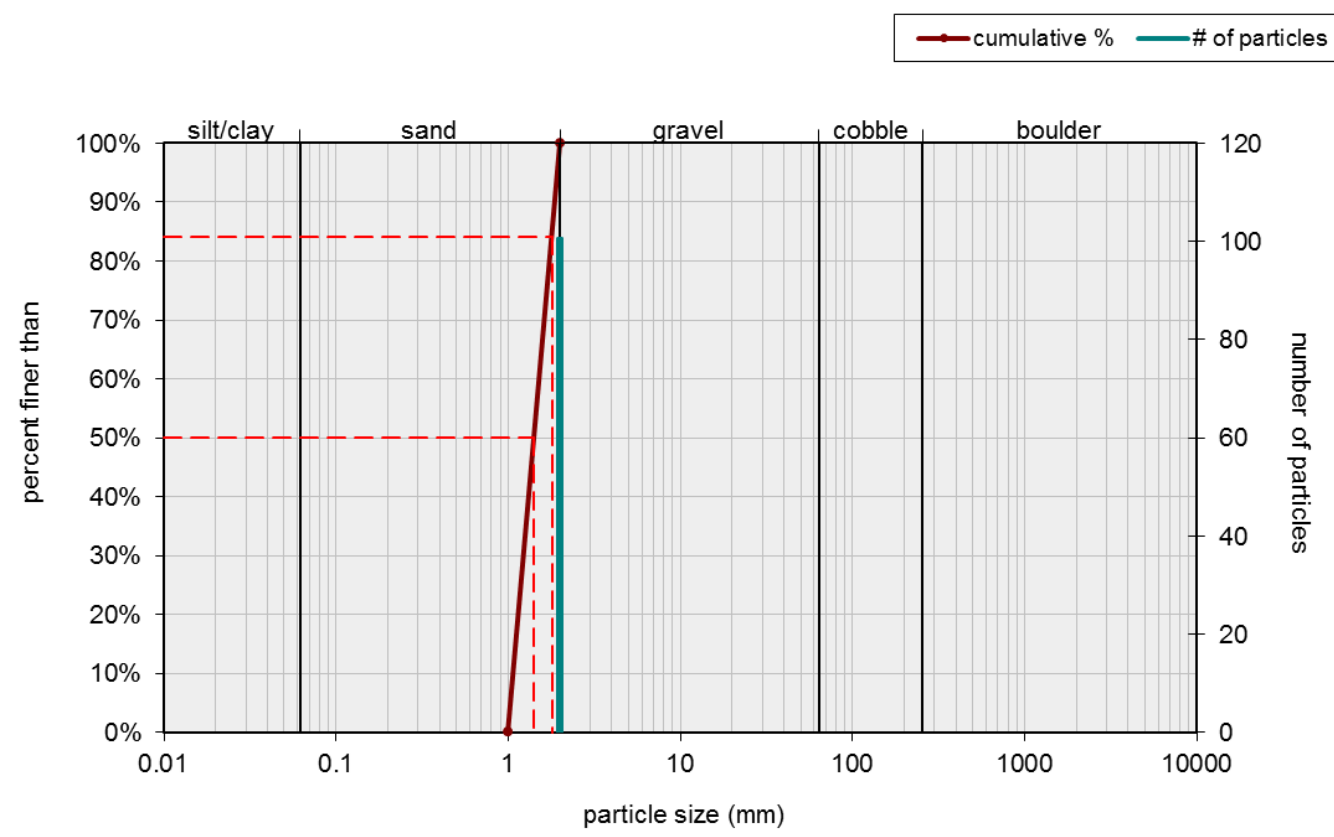

Figure 52. Grain size distribution at Whiteday Creek South (WDS). Data from pebble count that was collected on $8 / 2 / 12$ and $8 / 30 / 12$.

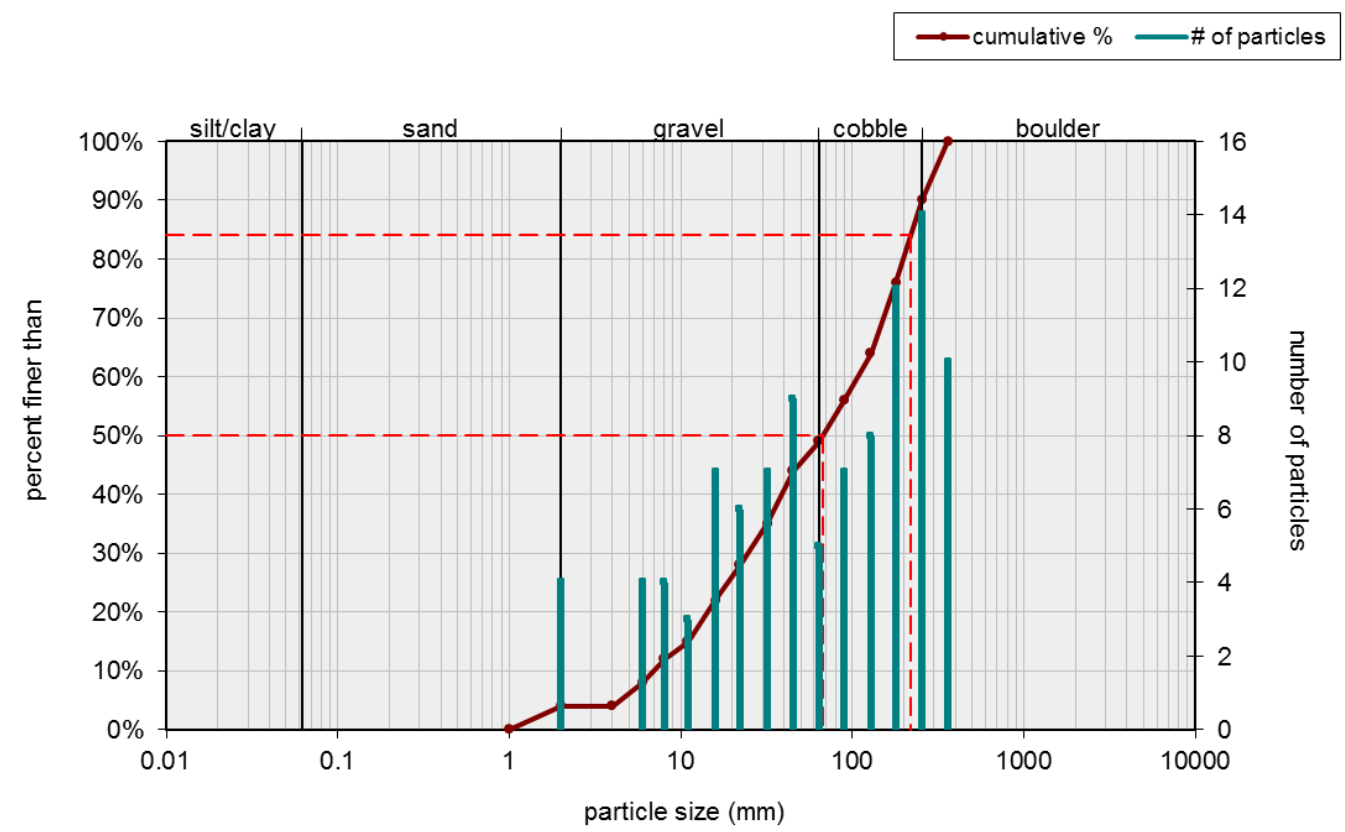

Figure 53. Grain size distribution at Downstream Reservoir (Ds Res). Data from pebble count that was collected on 5/24/12. 


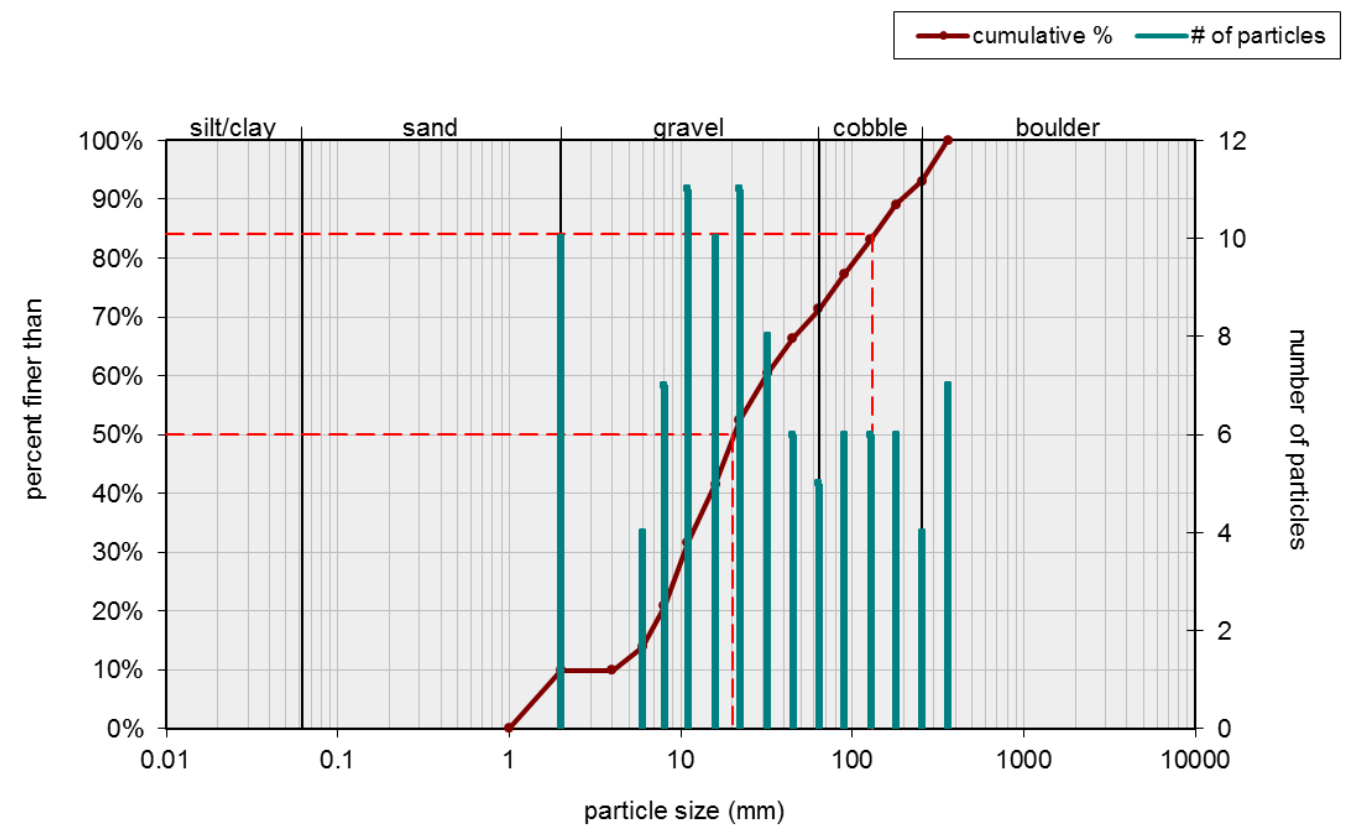

Figure 54. Grain size distribution at Downstream Reservoir (Ds Res). Data from pebble count that was collected on 7/3/12.

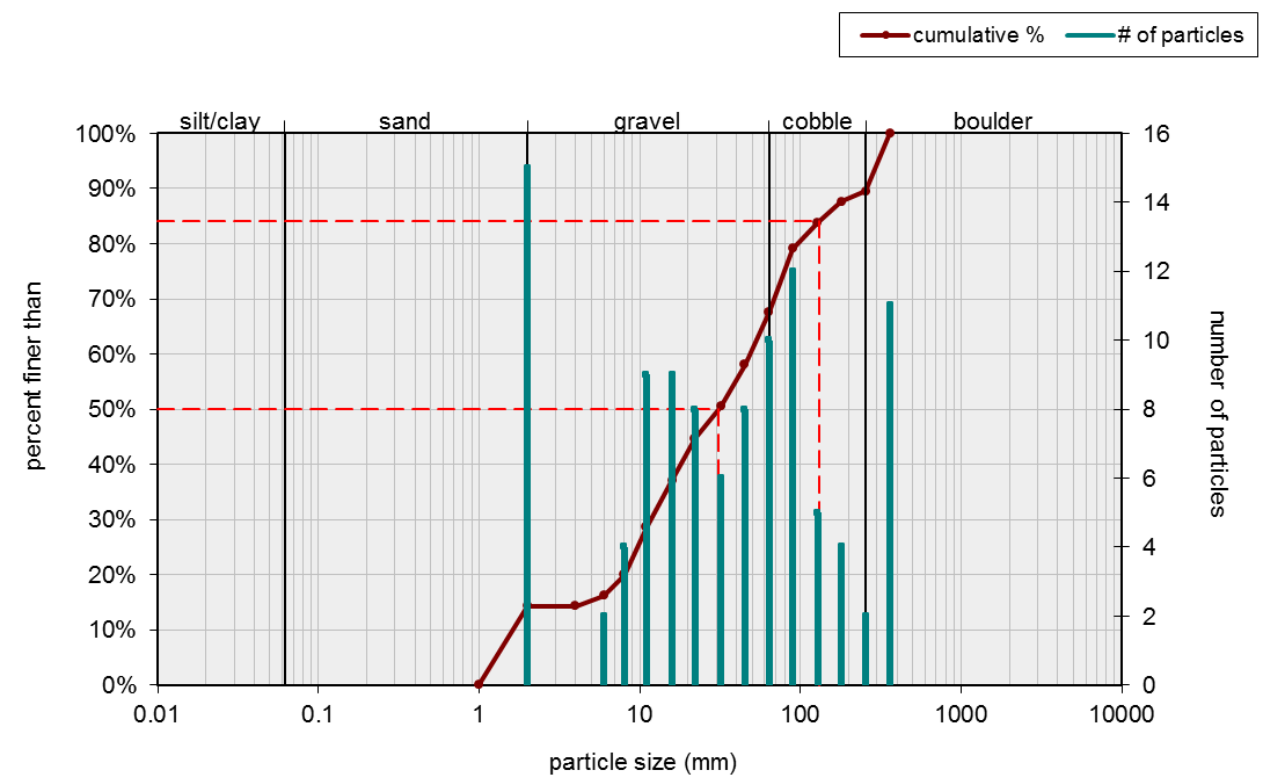

Figure 55. Grain size distribution at Downstream Reservoir (Ds Res). Data from pebble count that was collected on $8 / 2 / 12$. 


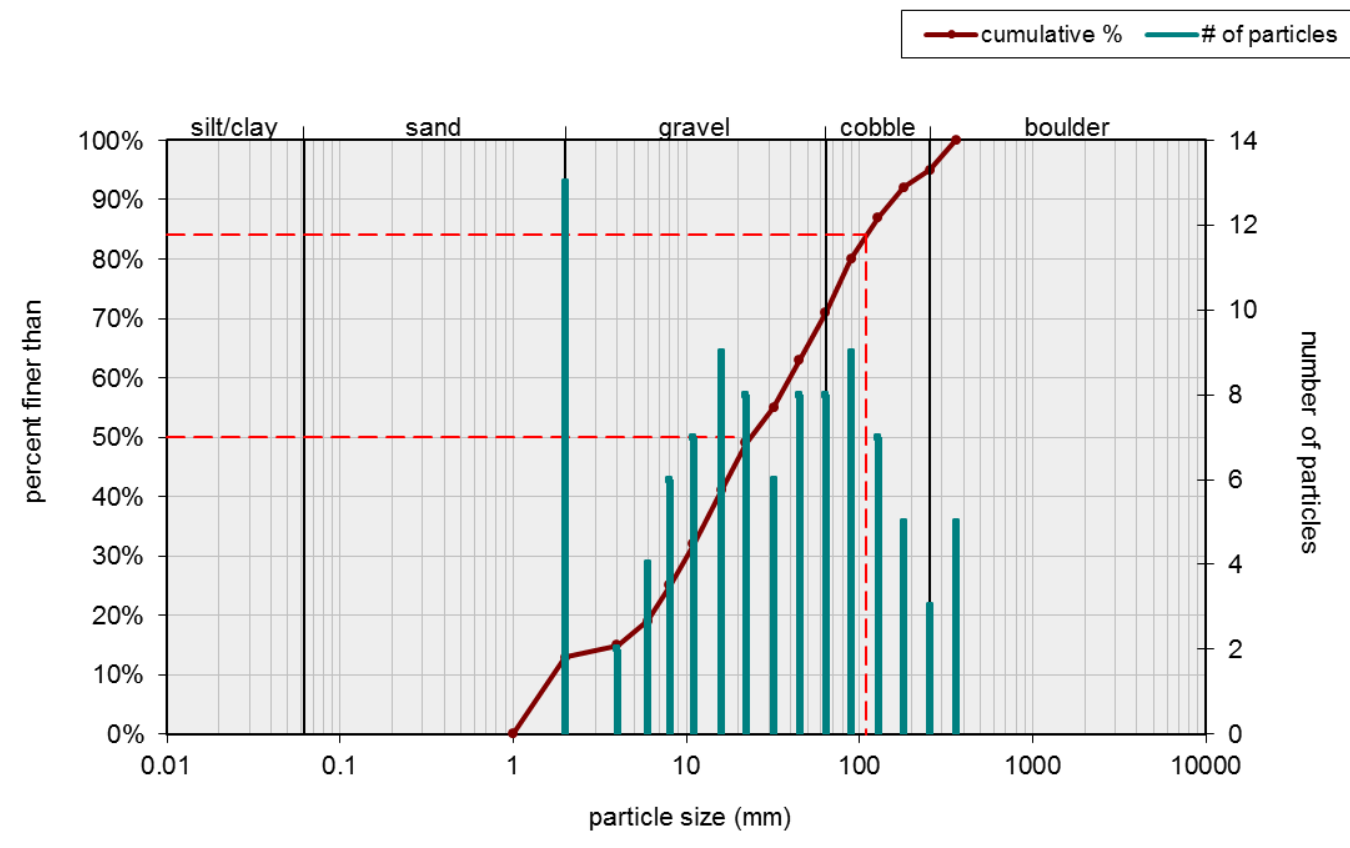

Figure 56. Grain size distribution at Downstream Reservoir (Ds Res). Data from pebble count that was collected on 8/30/12. 


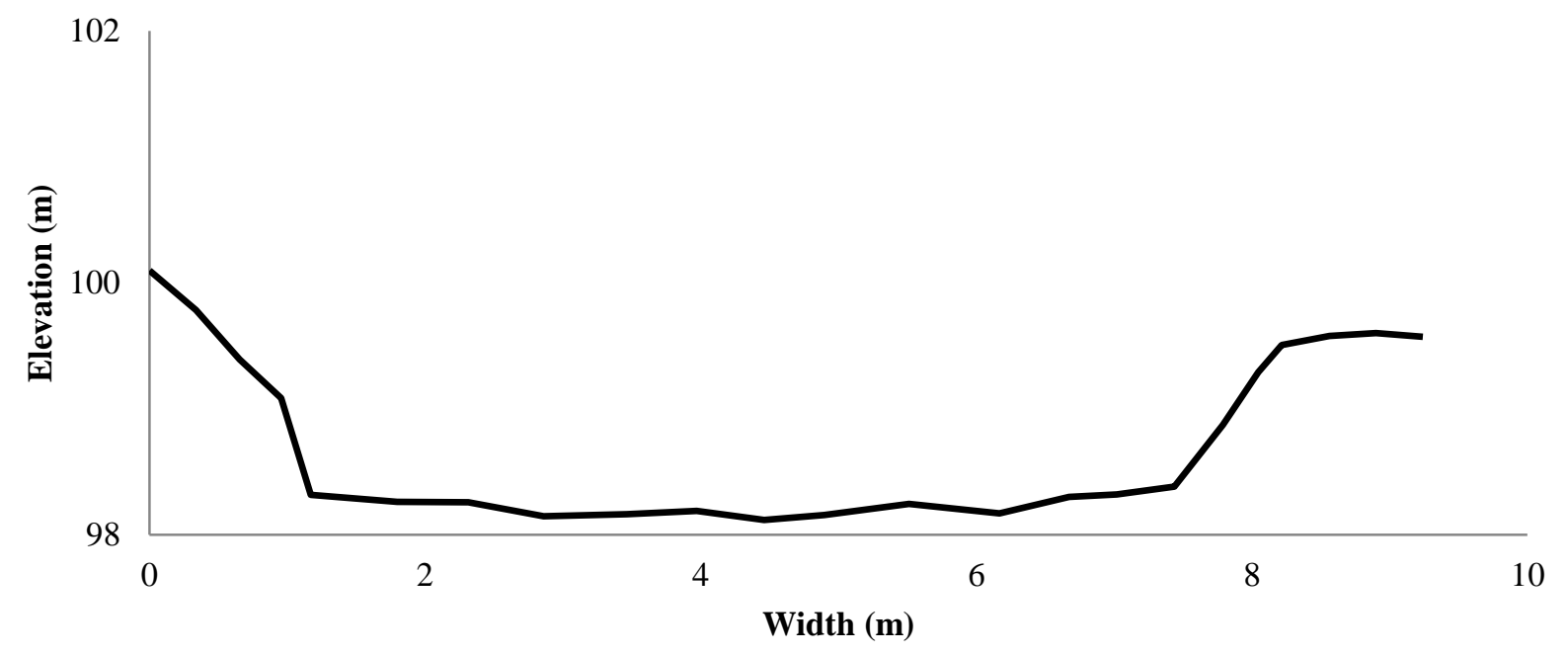

Figure 57. Stream cross-section at Lick Run North (Lck N). Cross-section is illustrated as an upstream view from sampling location.

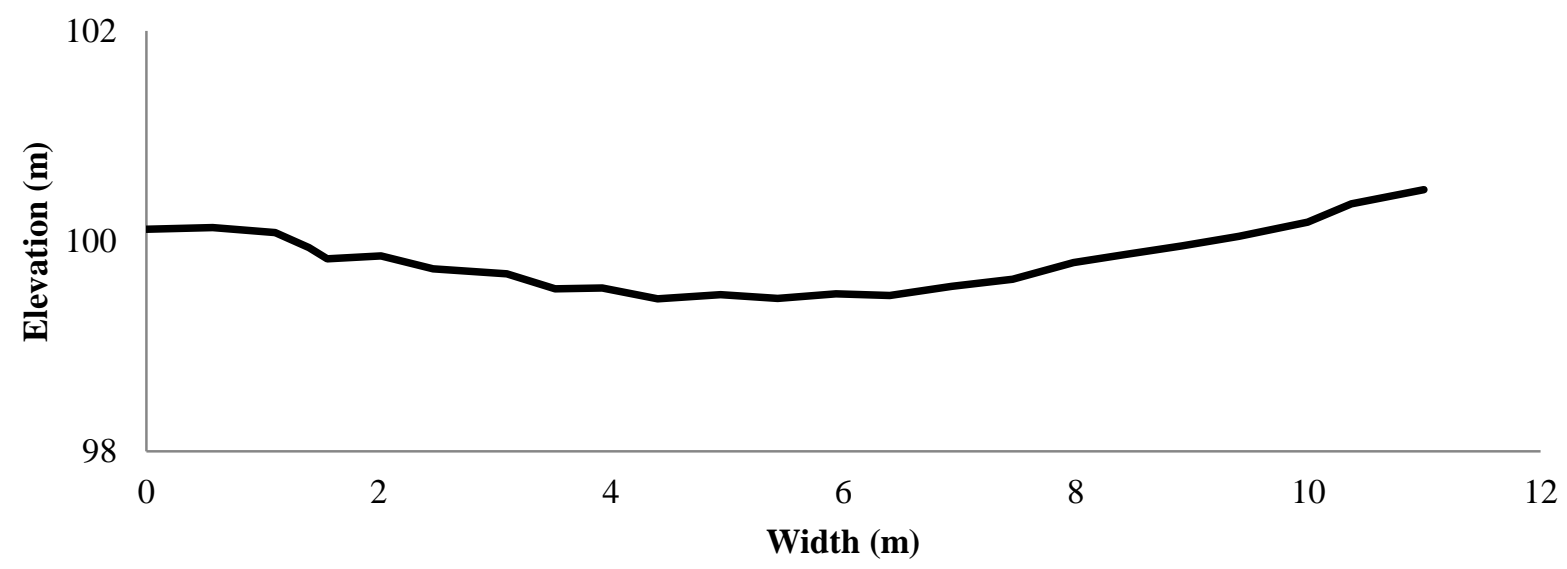

Figure 58. Stream cross-section at south Lick Run (S Lck). Cross-section is illustrated as an upstream view from sampling location. 


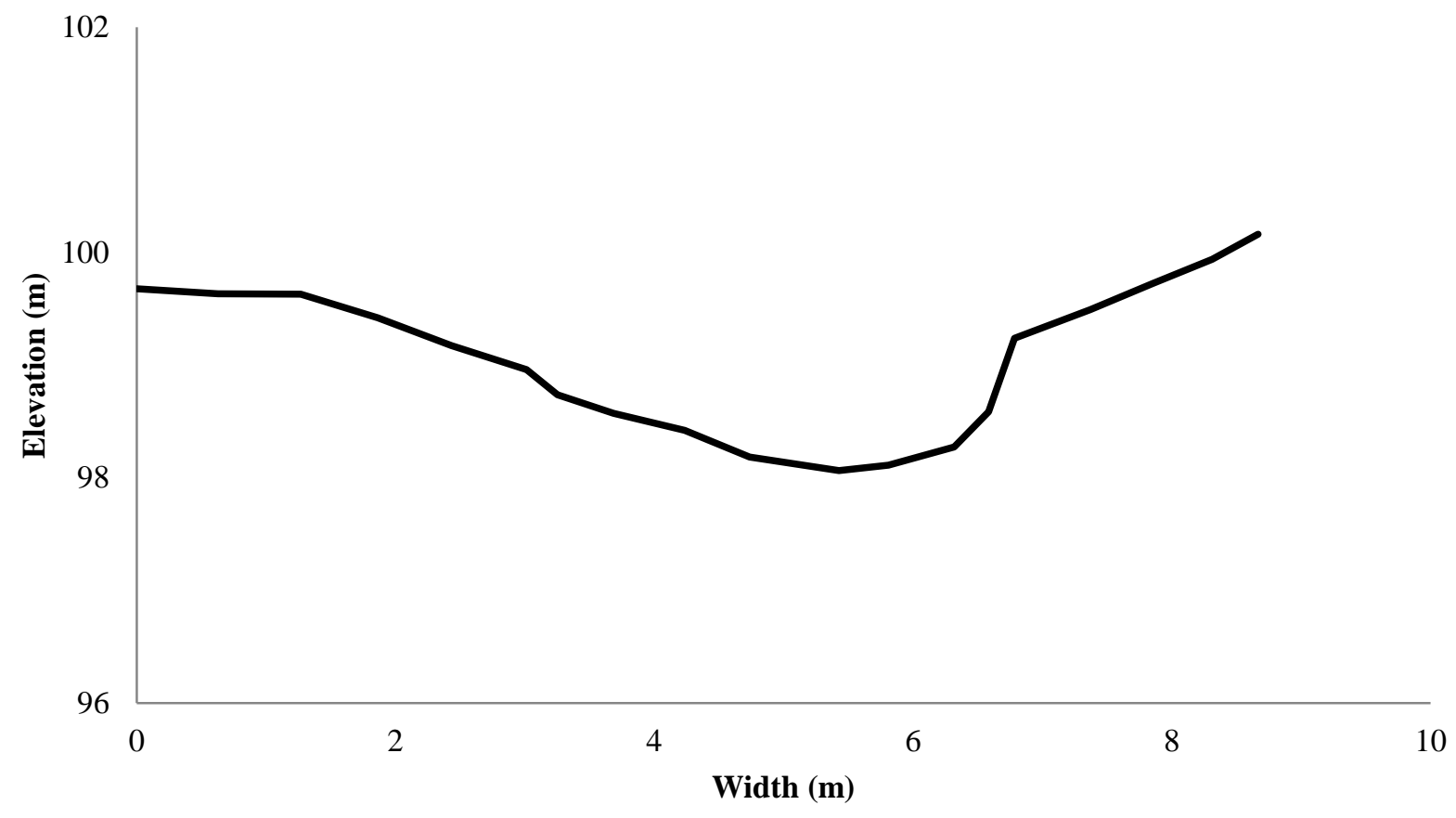

Figure 59. Stream cross-section at Reservoir (Resv). Cross-section is illustrated as an upstream view from sampling location.

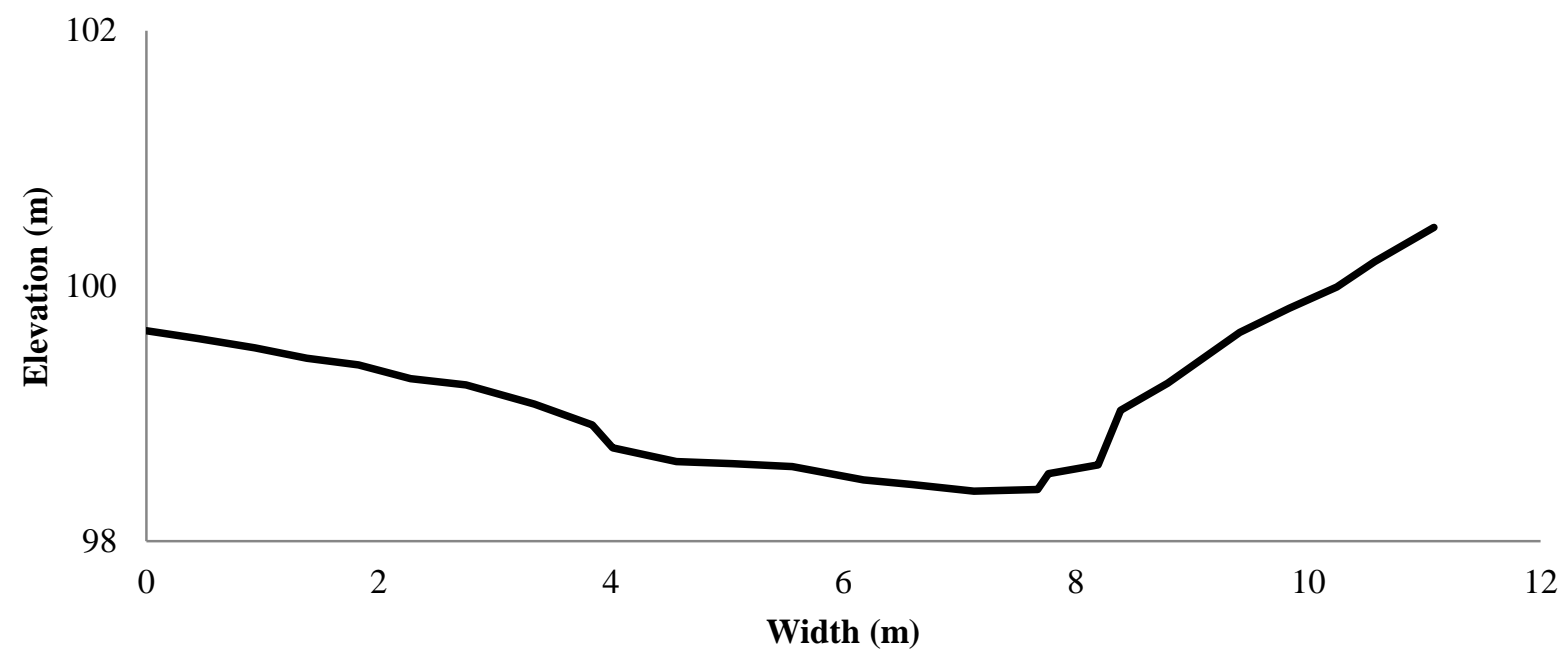

Figure 60. Stream cross-section at Laurel Run Southeast (Lrn SE). Cross-section is illustrated as an upstream view from sampling location. 


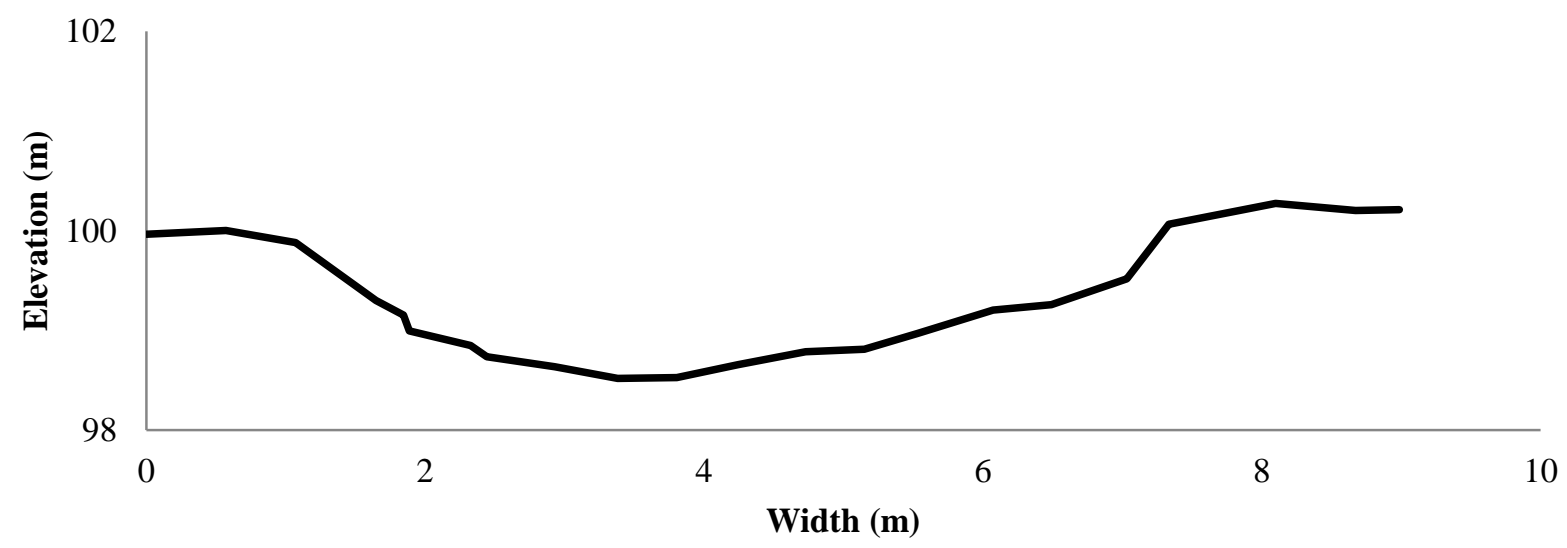

Figure 61. Stream cross-section at South Laurel Run ( S Lrn). Cross-section is illustrated as an upstream view from sampling location.

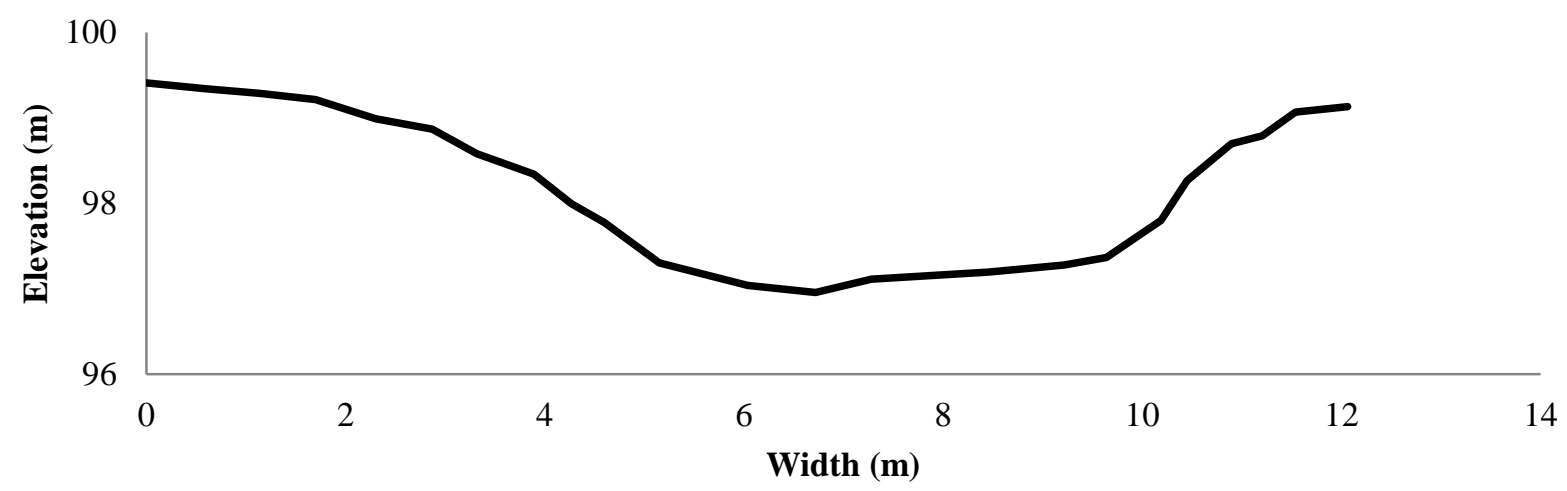

Figure 62. Stream cross-section at Whiteday Creek Cherry Run Road (WD CHRY RD). Cross-section is illustrated as an upstream view from sampling location. 


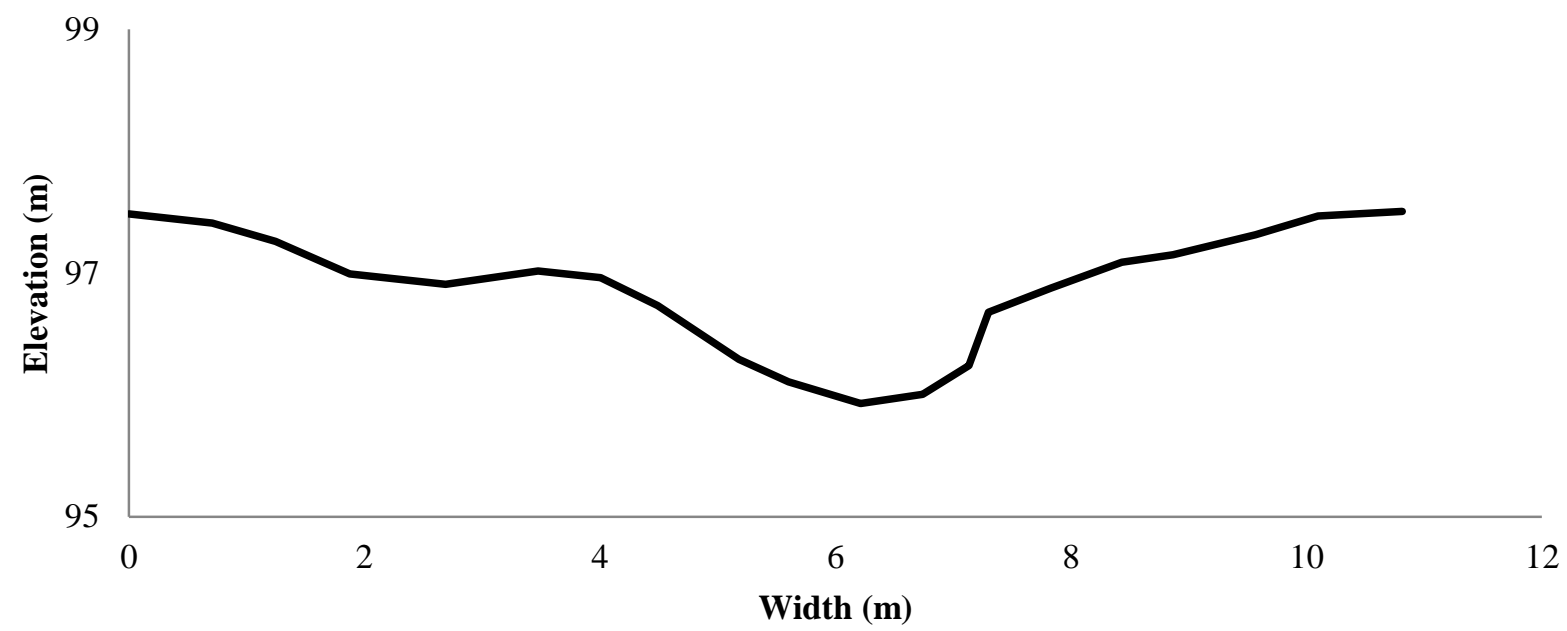

Figure 63. Stream cross-section at Whiteday Creek South (WDS). Cross-section is illustrated as an upstream view from sampling location.

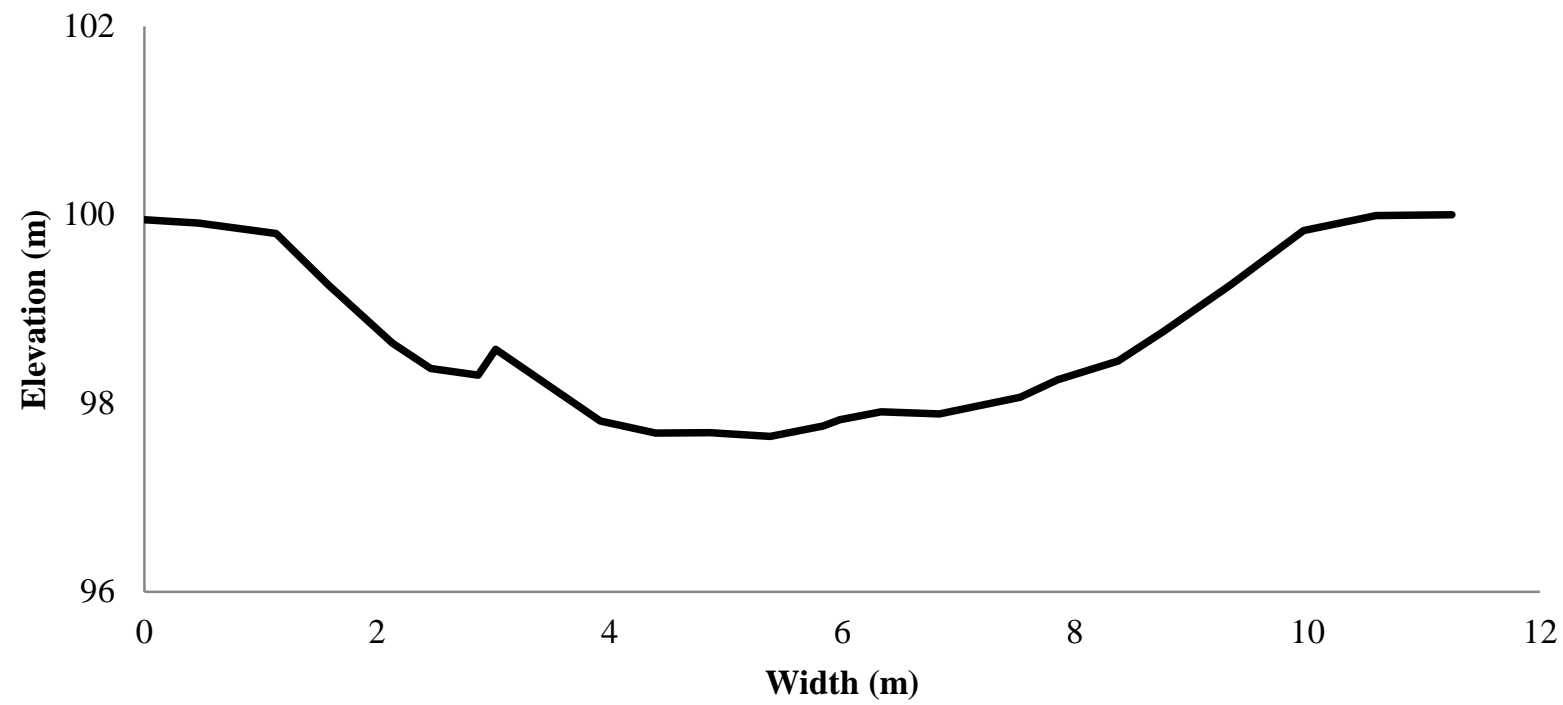

Figure 64. Stream cross-section at Downstream Reservoir (Ds Res). Cross-section is illustrated as an upstream view from sampling location. 
Table 10. Macroinvertebrate collection results from Lick Run North (Lck N). Macroinvertebrates were collected 5/10/12.

\begin{tabular}{lc}
\hline Type & Amount \\
\hline Patterned Stonefly & 13 \\
Common Stonefly & 28 \\
Giant Stonefly & 1 \\
Cranefly & 1 \\
Aquatic Worms & 2 \\
Norhtern Case Caddisfly & 2 \\
Free Living Caddisfly & 17 \\
Spiny Crawler Mayfly & 2 \\
Burrowing Mayfly & 12 \\
Non-bitting Midge & 2 \\
\hline
\end{tabular}

Table 11. Macroinvertebrate collection results from South Lick Run (S Lck). Macroinvertebrates were collected 5/10/12.

\begin{tabular}{|l|c|}
\hline \multicolumn{1}{|c|}{ Type } & Amount \\
\hline Patterned Stonefly & 1 \\
\hline Common Stonefly & 49 \\
\hline Roach-like Stonefly & 1 \\
\hline Aquatic Sowbug & 1 \\
\hline Common Netspinner & 22 \\
\hline Leech & 1 \\
\hline Dragonfly & 5 \\
\hline Salamander & 10 \\
\hline Non-bitting Midge & 3 \\
\hline Crayfish & 11 \\
\hline Cranefly & 21 \\
\hline
\end{tabular}

Table 12. Macroinvertebrate collection results from Reservoir (Resv). Macroinvertebrates were collected 5/10/12.

\begin{tabular}{lc}
\hline \multicolumn{1}{c}{ Type } & Amount \\
\hline Aquatic Sowbug & 1 \\
Spiny Crawler Mayfly & 49 \\
Burrowing Mayfly & 1 \\
Patterned Mayfly & 1 \\
Aquatic Worms & 22 \\
Leech & 1 \\
Common NetSpinner & 5 \\
\hline
\end{tabular}


Table 13. Macroinvertebrate collection results from Laurel Run Southeast (Lrn SE). Macroinvertebrates were collected 5/10/12.

\begin{tabular}{lc}
\hline Type & Amount \\
\hline Crayfish & 4 \\
Salamander & 10 \\
Cranefly & 2 \\
Pronggill Mayfly & 3 \\
Burrowing Mayfly & 15 \\
Common Stonefly & 13 \\
Patterned Stonefly & 10 \\
Northern Case Caddisfly & 1 \\
Case-Maker Caddislfy & 2 \\
Common Netspinner & 12 \\
Non-bitting Midge & 2 \\
\hline
\end{tabular}

Table 14. Macroinvertebrate collection results from South Laurel Run (S Lrn). Macroinvertebrates were collected 5/10/12.

\begin{tabular}{lc}
\hline Type & Amount \\
\hline Aquatic Worm & 1 \\
Gold/Common Stonefly & 1 \\
Aquatic Sowbug & 1 \\
Patterned Stonefly & 1 \\
Riffle Beetle & 1 \\
Giant Stonefly & 5 \\
Crane fly & 1 \\
Common Netspinner & 9 \\
Case-Maker Caddislfy & 20 \\
Salamander & 1 \\
Crayfish & 6 \\
Mayfly(3 types) & 39 \\
\hline
\end{tabular}


Table 15. Macroinvertebrate collection results from Whiteday Cherryrun Road (WD CHRY RD). Macroinvertebrates were collected 5/10/12.

\begin{tabular}{lc}
\hline Type & Amount \\
\hline Crayfish & 3 \\
Burrowing Mayfly & 7 \\
Spiny Crawler Mayfly & 11 \\
Aquatic Worms & 23 \\
Free-living Caddisfly & 18 \\
Saddle Case Caddisfly & 3 \\
Riffle Bettle & 1 \\
Black Fly & 2 \\
Roach Like Stonefly & 2 \\
Water Penny & 12 \\
\hline
\end{tabular}

Table 16. Macroinvertebrate collection results from Downstream Reservoir (Ds Res). Macroinvertebrates were collected 5/10/12.

\begin{tabular}{lc}
\hline \multicolumn{1}{c}{ Type } & Amount \\
\hline Crayfish & 7 \\
Cranefly & 1 \\
Dragonfly & 1 \\
Aquatic Sowbug & 1 \\
Northern Case Caddisfly & 2 \\
Free-Living Caddisfly & 1 \\
Small Minnow Mayfly & 2 \\
Burrowing Mayfly & 13 \\
Pronggil Mayfly & 5 \\
\hline
\end{tabular}



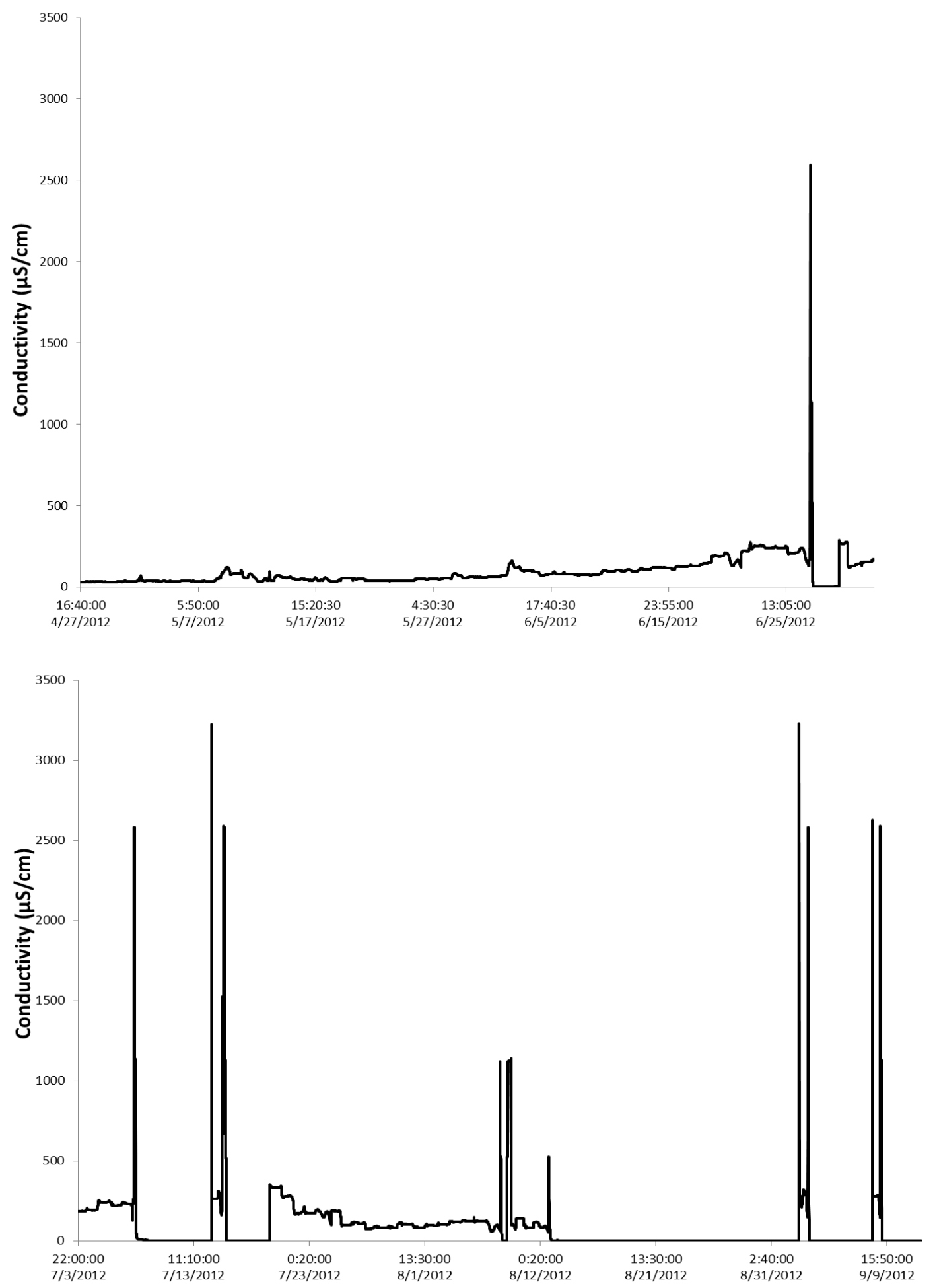

Figure 65. Solinst continuous levelogger conductivity data for Resv over the duration of the monitoring period. 

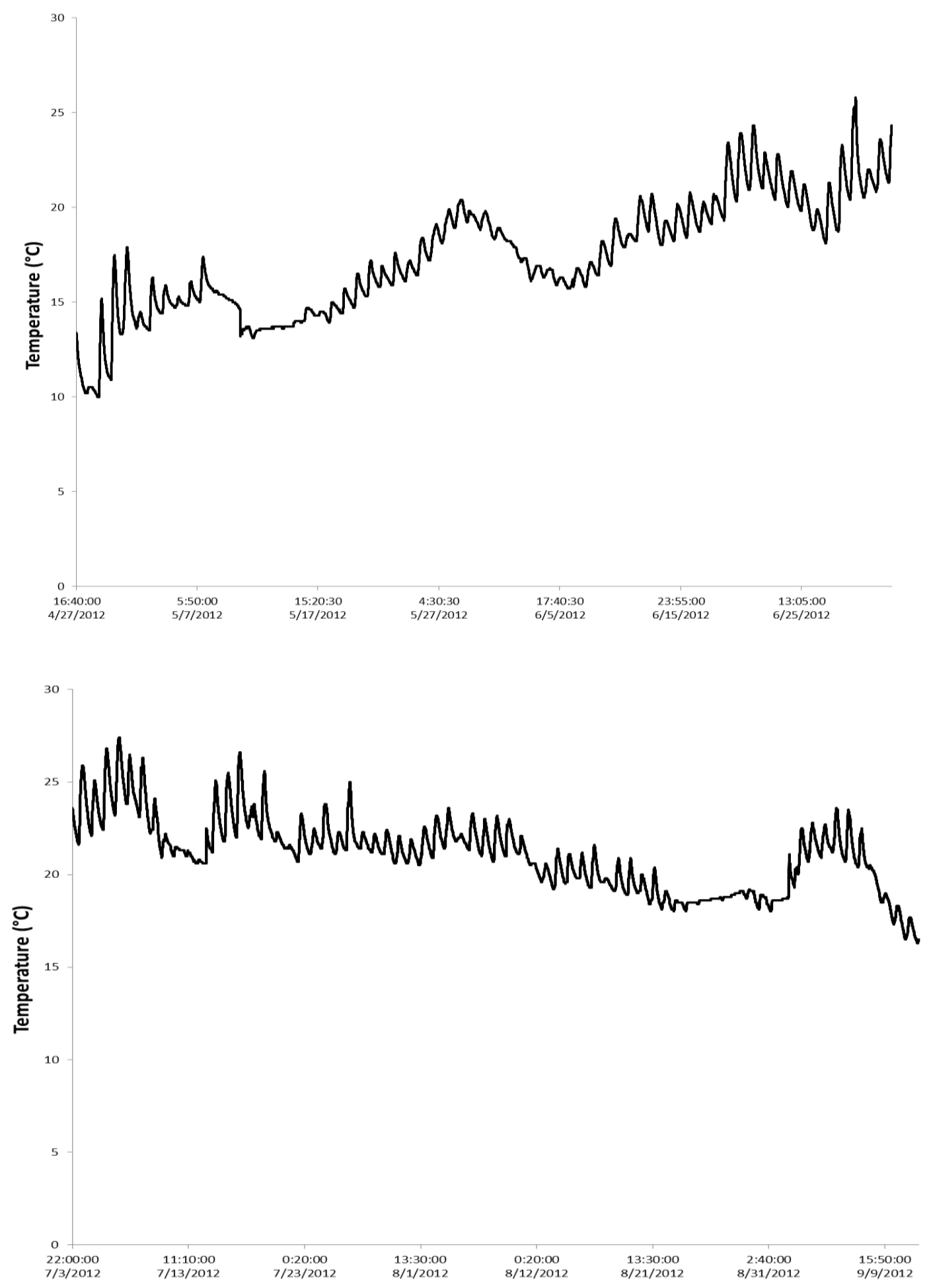

Figure 66. Solinst continuous levelogger temperature data for Resv over the duration of the monitoring period. 

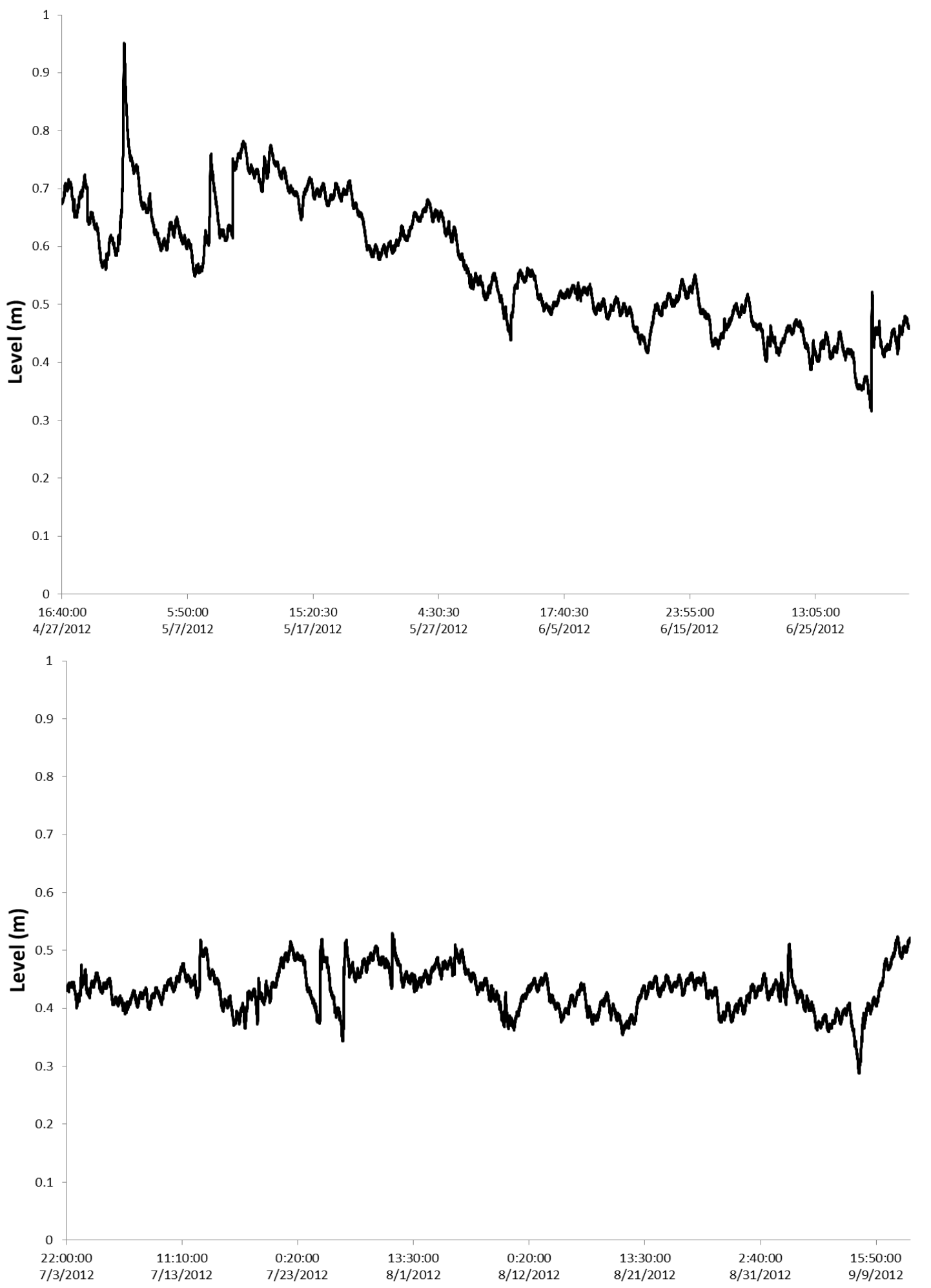

Figure 67. Solinst continuous levelogger water level data for Resv over the duration of the monitoring period. 

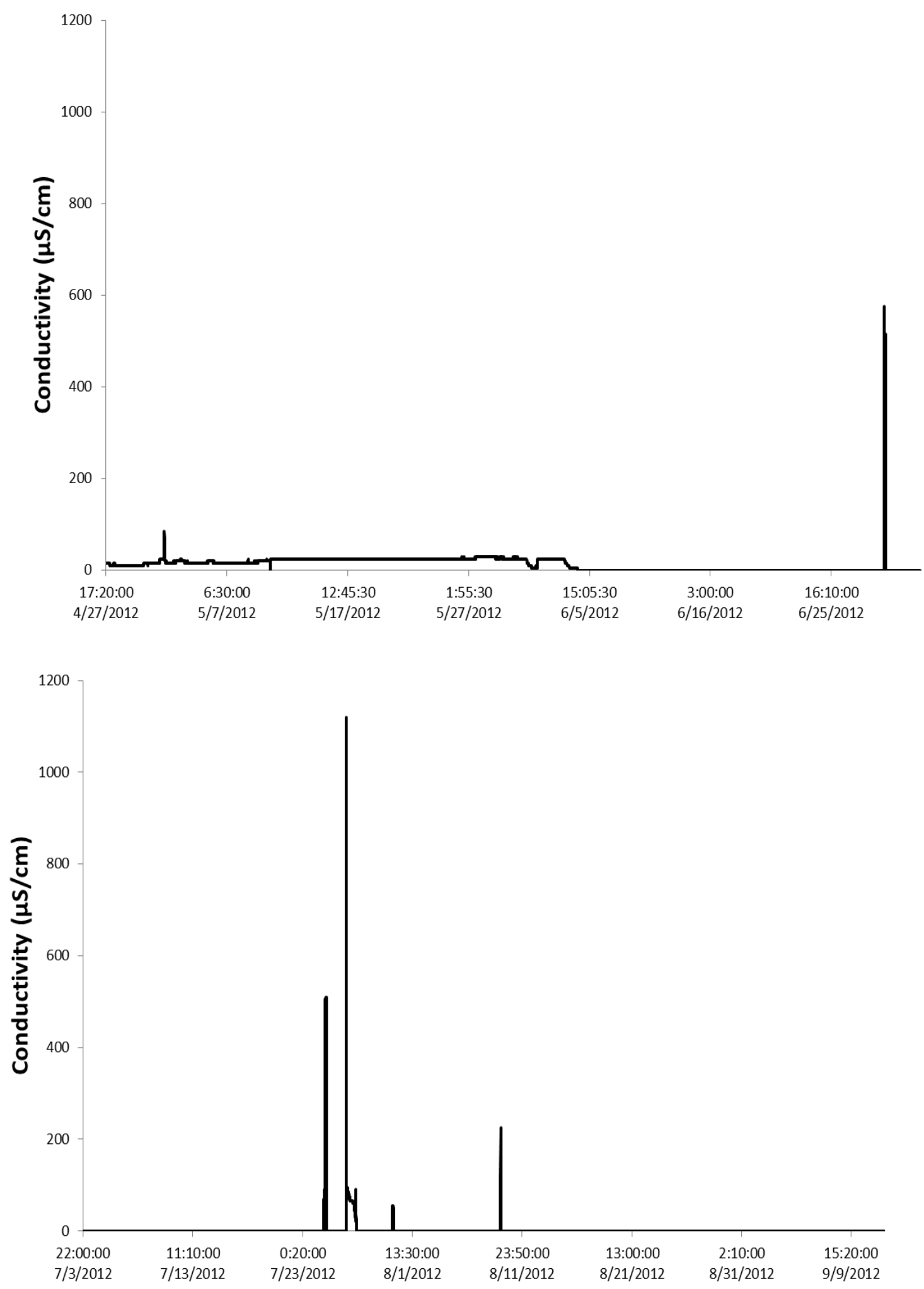

Figure 68. Solinst continuous levelogger conductivity data for Lrn SE over the duration of the monitoring period. 

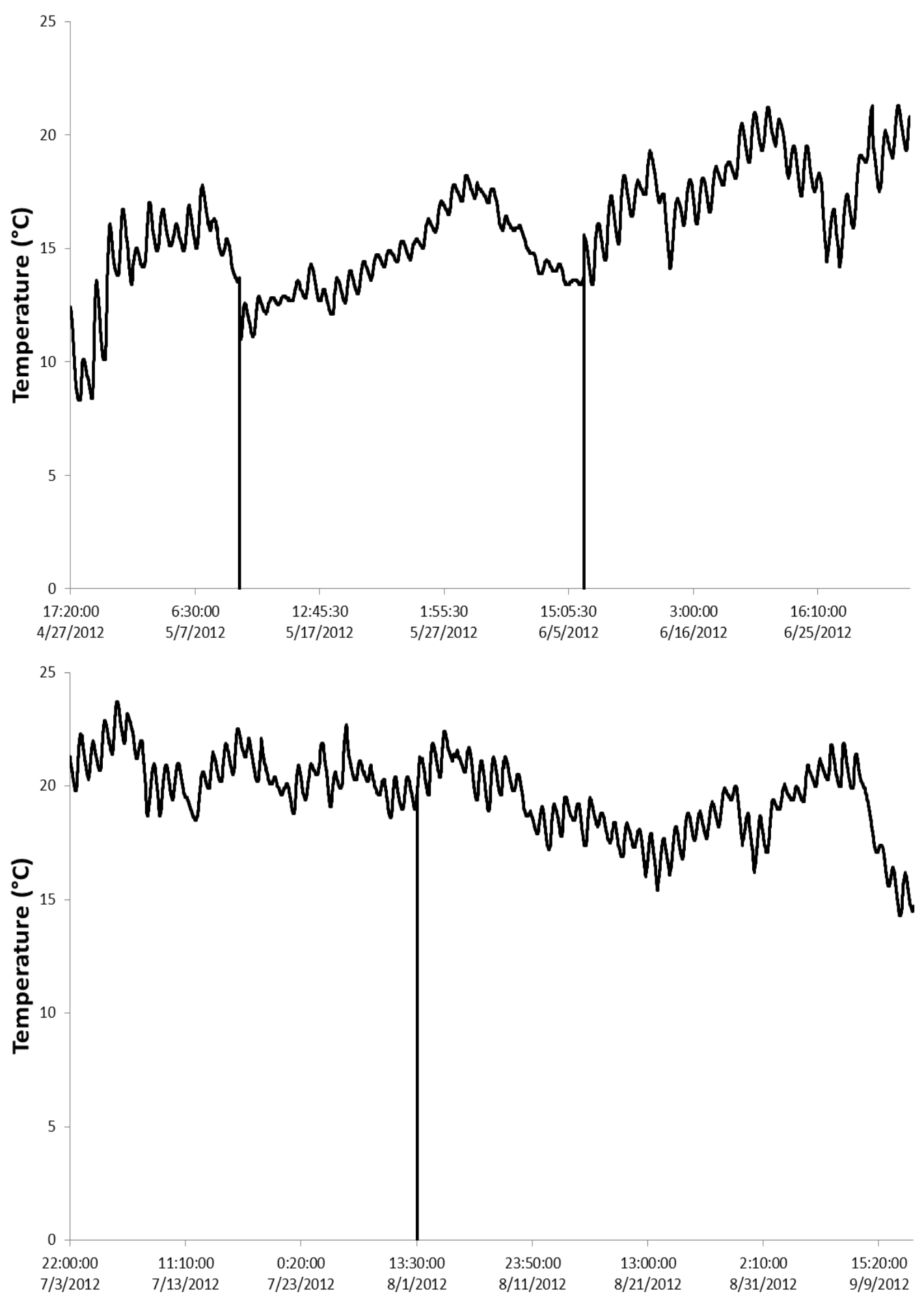

Figure 69. Solinst continuous levelogger temperature data for Lrn SE over the duration of the monitoring period. Data points that abruptly equal zero are measurements that occurred when removing levelogger from site to download data. 

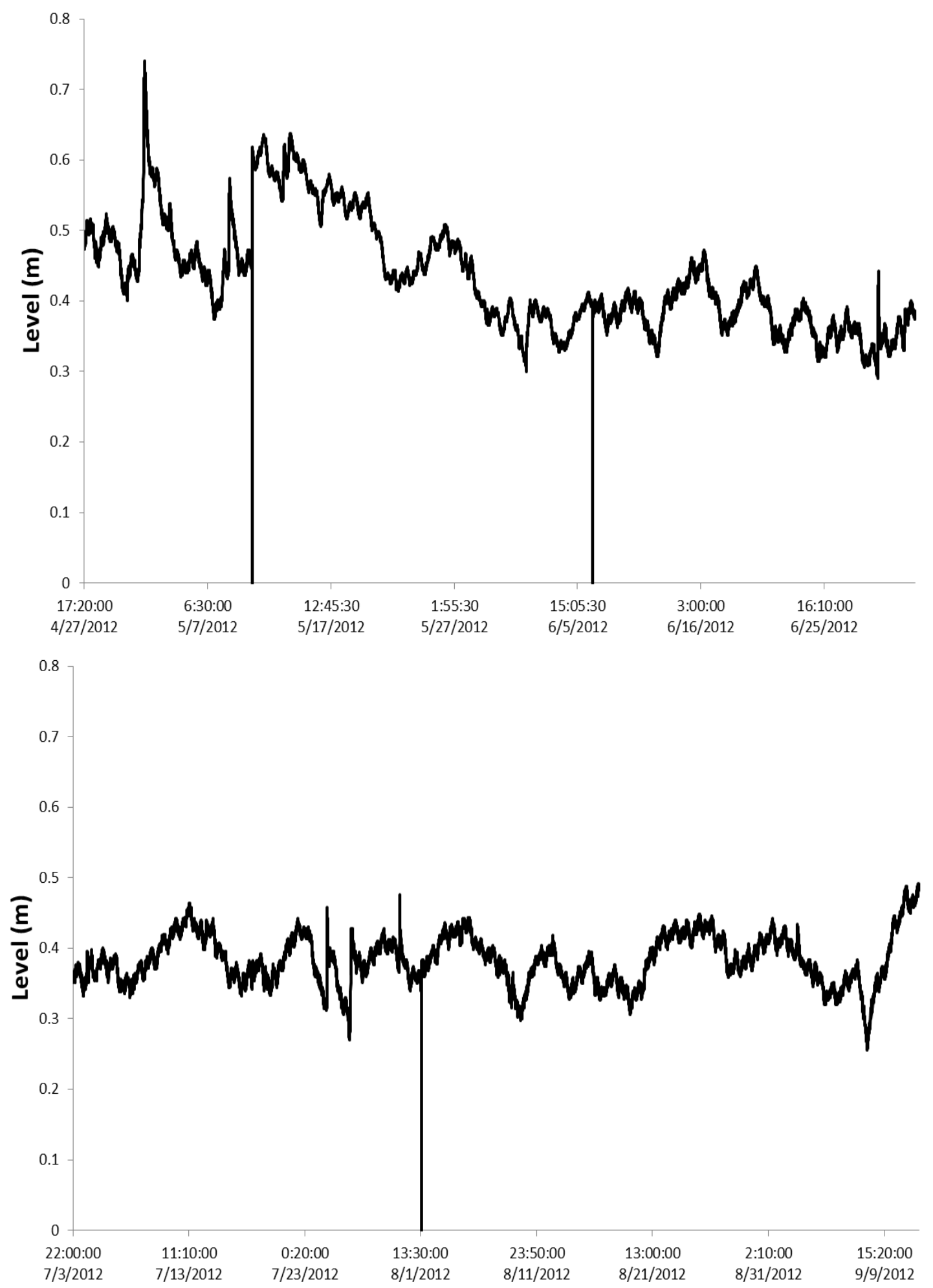

Figure 70. Solinst continuous levelogger water level data for Lrn SE over the duration of the monitoring period. Data points that abruptly equal zero are measurements that occurred when removing levelogger from site to download data 

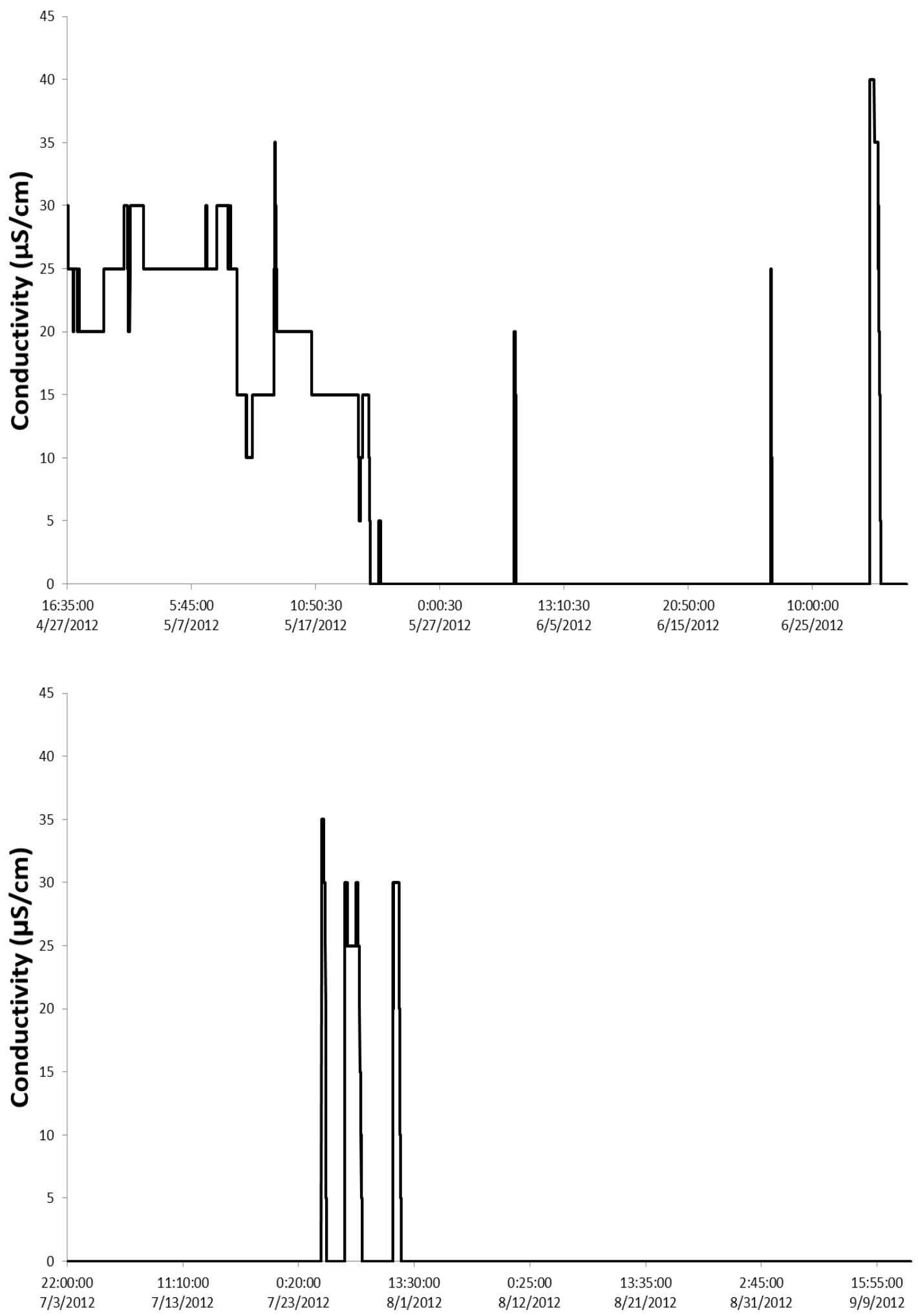

Figure 71. Solinst continuous levelogger conductivity data for S Lrn over the duration of the monitoring period. 

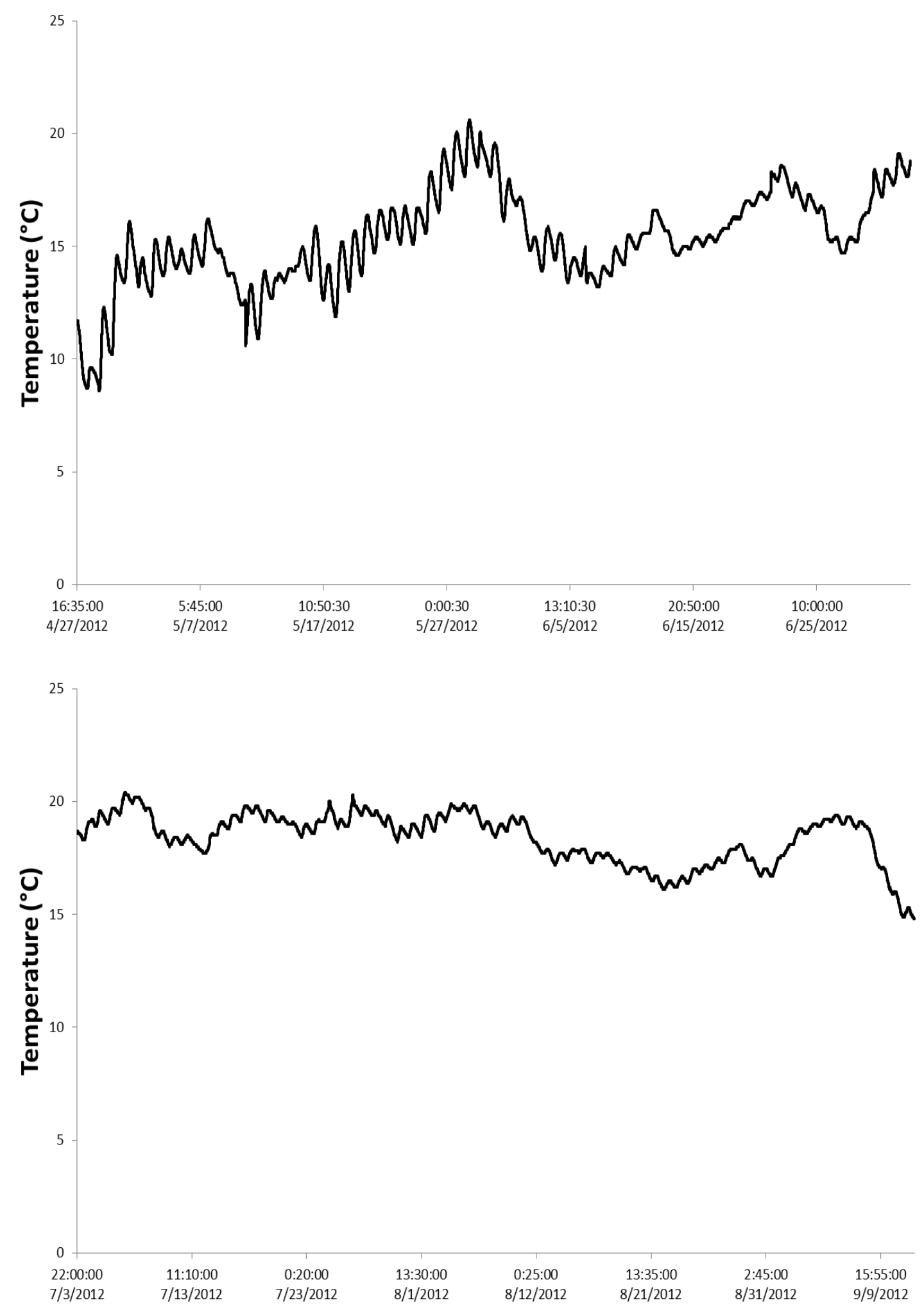

Figure 72. Solinst continuous levelogger temperature data for S Lrn over the duration of the monitoring period. 



Figure 73. Solinst continuous levelogger water level data for $\mathrm{S}$ Lrn over the duration of the monitoring period. 


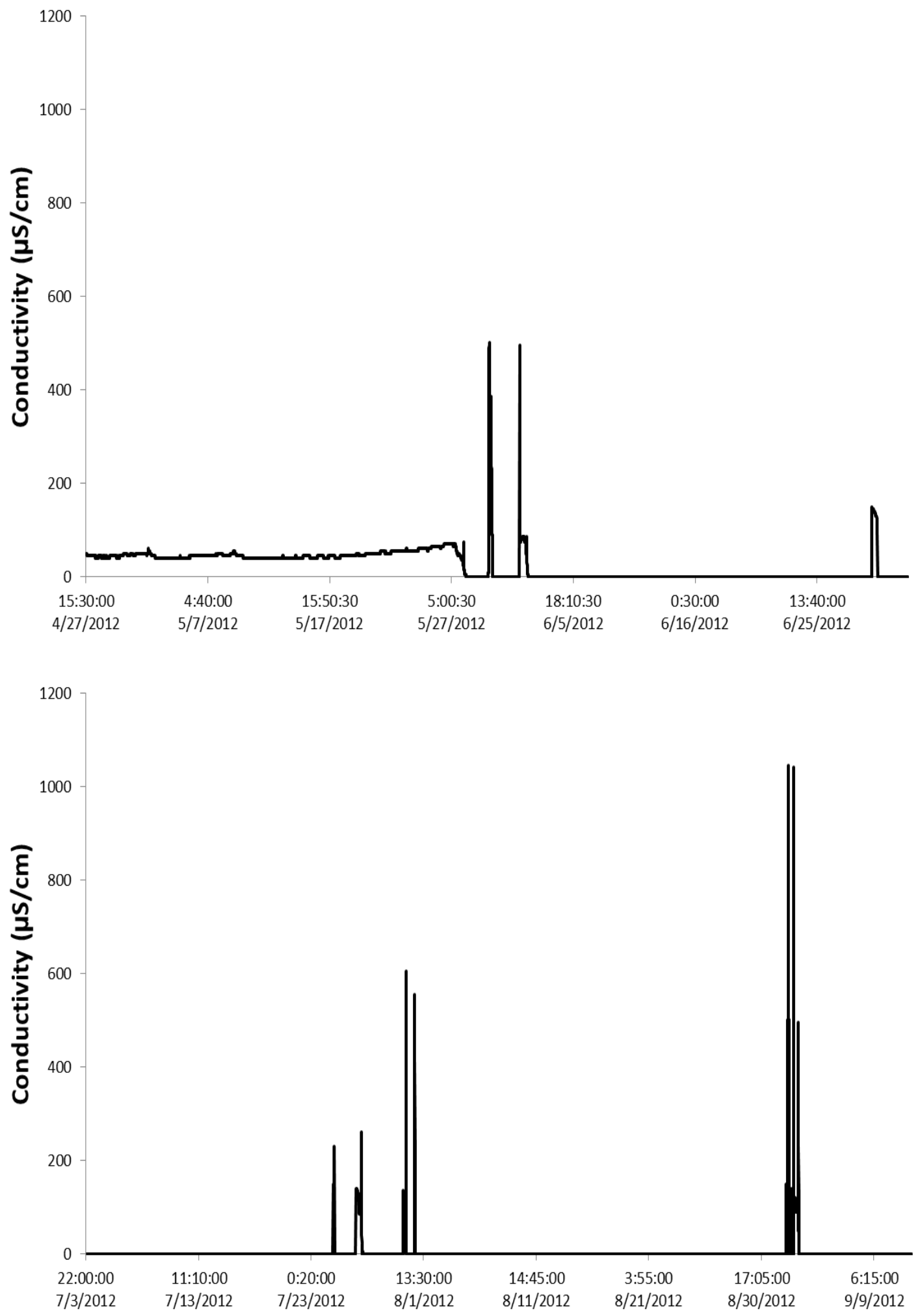

Figure 74. Solinst continuous levelogger conductivity data for Ds Res over the duration of the monitoring period. 




Figure 75. Solinst continuous levelogger temperature data for Ds Res over the duration of the monitoring period. 


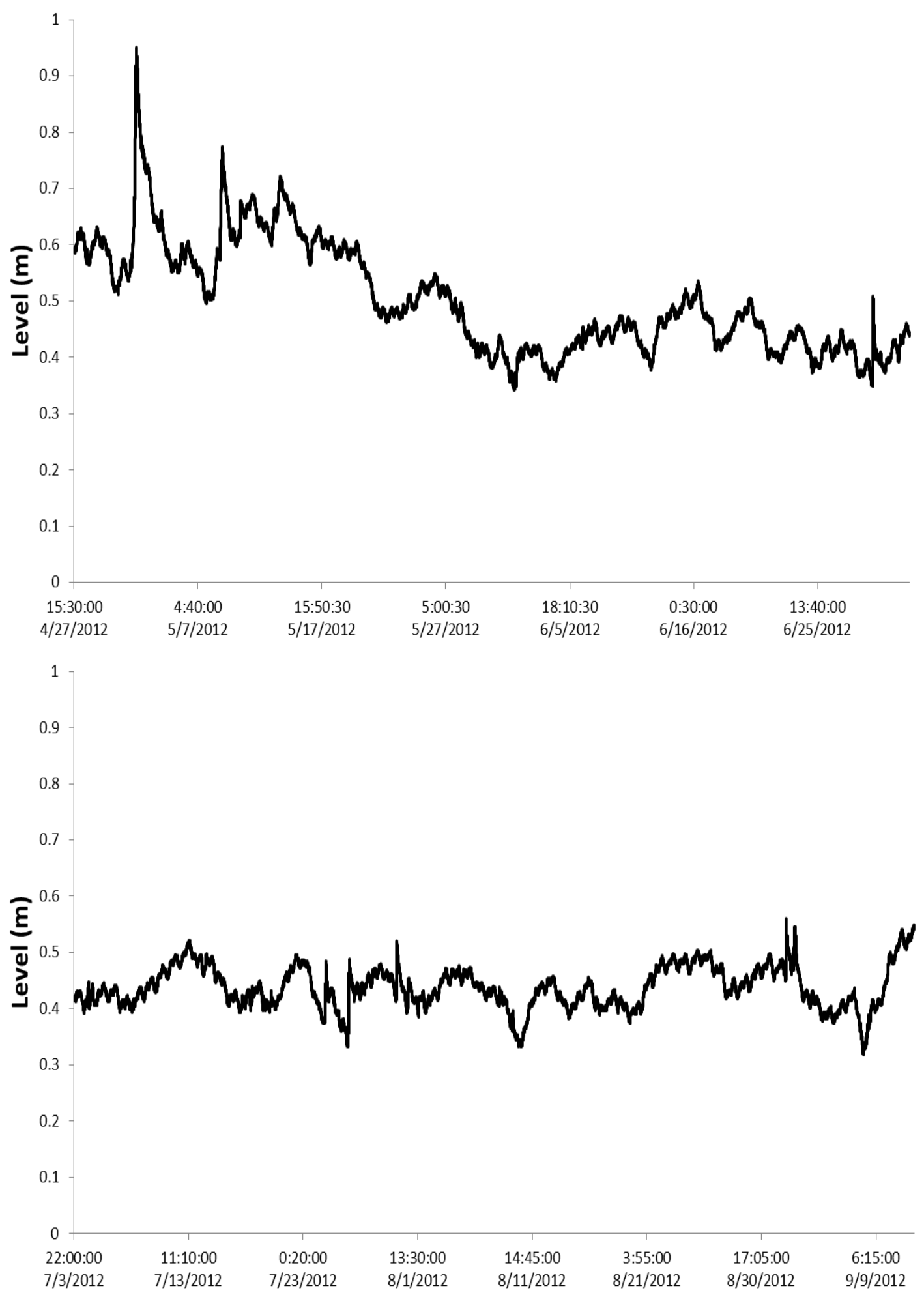

Figure 76. Solinst continuous levelogger water level data for Ds Res over the duration of the monitoring period. 